4 norden 



\section{The Valuation of Habitats for Conservation}

- Concepts, methods and applications

Rasmus Ejrnoes, Odd Stabbetorp, Harald Bratli, Jaan Liira, Erik Aude, Bettina Nygaard \& Roar Skovlund Poulsen

TemaNord 2005:519 
The Valuation of Habitats for Conservation

- Concepts, methods and applications

TemaNord 2005:519

(C) Nordisk Ministerråd, København 2005

ISBN 92-893-1132-0

Tilrettelæggelse: Publikationsenheden, Nordisk Ministerråd

Publikationen kan bestilles på www.norden.org/order. Flere publikationer på

www.norden.org/publikationer

Printed in Denmark

Nordisk Ministerråd

Store Strandstræde 18

DK-1255 København K

Telefon $(+45) 33960200$

Telefax $(+45) 33960202$
Nordisk Råd

Store Strandstræde 18

DK-1255 København K

Telefon $(+45) 33960400$

Telefax $(+45) 33111870$

www.norden.org

\section{Nordic Environmental Co-operation}

Environmental co-operation is aimed at contributing to the improvement of the environment and forestall problems in the Nordic countries as well as on the international scene. The co-operation is conducted by the Nordic Committee of Senior Officials for Environmental Affairs. The co-operation endeavours to advance joint aims for Action Plans and joint projects, exchange of information and assistance, e.g. to Eastern Europe, through the Nordic Environmental Finance Corporation (NEFCO).

\section{Nordic co-operation}

Nordic co-operation, one of the oldest and most wide-ranging regional partnerships in the world, involves Denmark, Finland, Iceland, Norway, Sweden, the Faroe Islands, Greenland and Åland. Cooperation reinforces the sense of Nordic community while respecting national differences and similarities, makes it possible to uphold Nordic interests in the world at large and promotes positive relations between neighbouring peoples.

Co-operation was formalised in 1952 when the Nordic Council was set up as a forum for parliamentarians and governments. The Helsinki Treaty of 1962 has formed the framework for Nordic partnership ever since. The Nordic Council of Ministers was set up in 1971 as the formal forum for cooperation between the governments of the Nordic countries and the political leadership of the autonomous areas, i.e. the Faroe Islands, Greenland and Åland. 


\section{Table of contents}

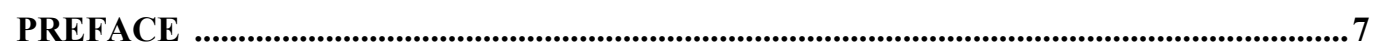

SUMMARY ..............................................................................................................................

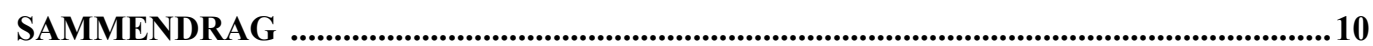

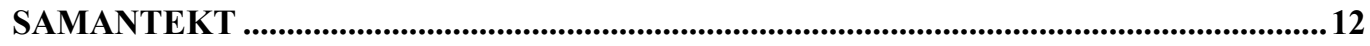

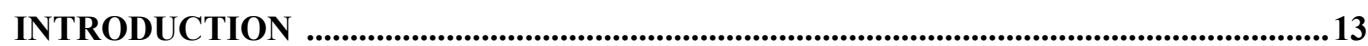

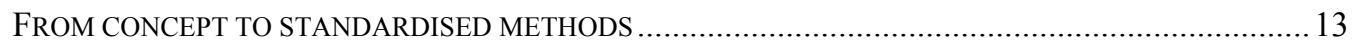

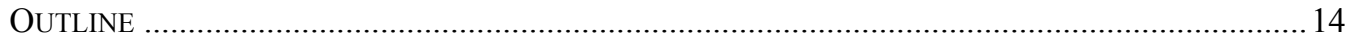

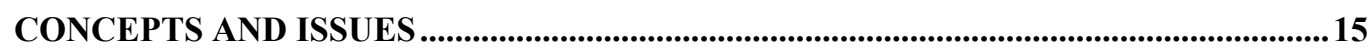

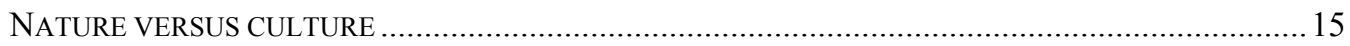

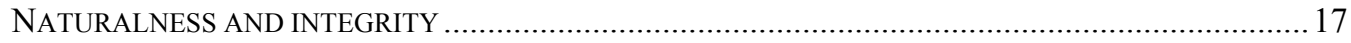

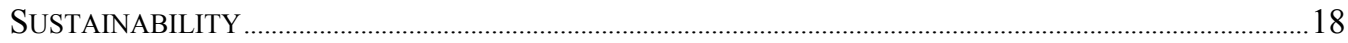

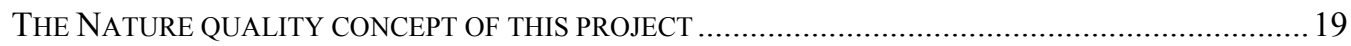

CRITERIA FOR VALUE ASSESSMENT ...............................................................................21

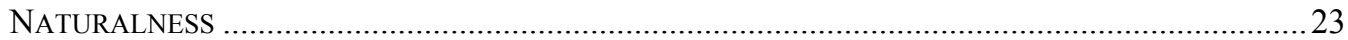

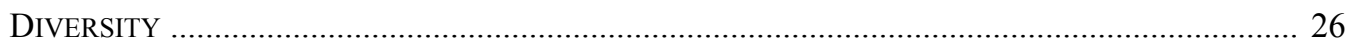

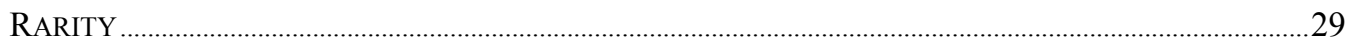

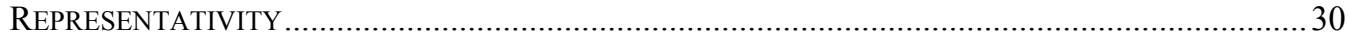

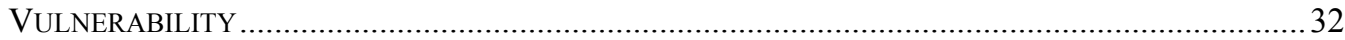

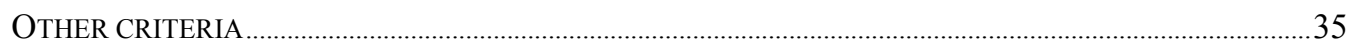

MODELS FOR VALUE ASSESSMENT ...................................................................................37

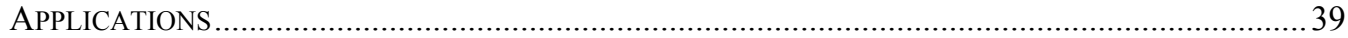

APPLICATION OF THE MODELS TO NORWEGIAN DATA ……………………………………………......

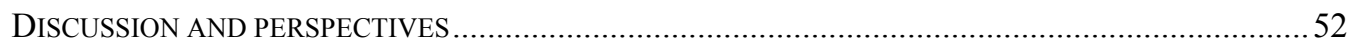

MODELS IN AN INFORMATION FRAMEWORK …....................................................57

MAPPING OF TERRESTRIAL HABITAT TYPES IN DENMARK ……..................................................... 57

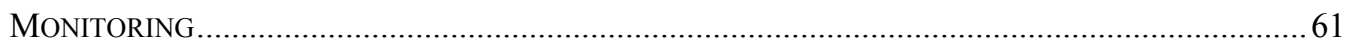

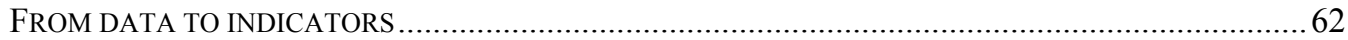

PUBLIC ACCESS THROUGH THE INTERNET ….........................................................67

METHODS FOR INTERACTIVE CLASSIFICATION ...............................................................................................67

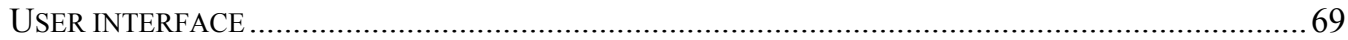

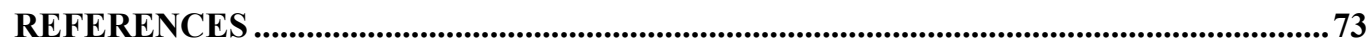




\section{Preface}

This report summarises the work carried out in the last two years of a four-year project funded by Nordic Council of Ministers. The objective of the project was to develop concepts and methods for assessment of nature quality in selected habitat types. The motivation for the project lies in increasing societal demands for information on the state of our natural environment and especially the state of our biodiversity has attracted increased attention over the last decades. Central to this project is the notion of quality as a key issue in biological conservation.

In 2001 the project published a TemaNord report (Mark 2001) summarising the work on using artificial neural networks for nature quality assessments on salt meadow vegetation. In 2001 and 2002 there was a change of project leader and a new project group was established. The project advanced further to the study of open land habitats in general, and grassland and heaths in particular. During the project period, workshops were planned and taken as opportunities for open discussion about concepts and method. Early in that process it became clear that statistical tools for assessment of natural condition rely heavily on criteria for favourable condition. It also became clear that these are not necessarily as objective as science would like them to be. Conservation is where biology and society meet. In the words of Paul L. Angermeier:

"Biological conservation depends on the ecological behavior of human societies. Because value-based policies limit conservation success more than does biological knowledge, the most crucial task facing conservationists is facilitating shifts in societal values toward more respect for nature. Such facilitation includes making ecological knowledge comprehensible to the public and connecting it to their deepseated values, and creating opportunities for the public to reconnect ecologically via hands-on participation in conservation programs. To be effective, conservationists will need to openly profess their values and persuade others that natural biotic diversity contributes significantly to the quality of human lives. Much of nature as we know it hinges on our success in these endeavors."

We publish the results of our study in the hope that they will provide more insight into the problems related to the definition of nature quality, and that this insight may inspire and inform the public debate. We also hope that the management tool-box we provide, including an approach to modelling and two new models, will be useful for conservation of valued ecosystems in the Nordic countries. We have been devoted to making the tools available to the public through the World Wide Web, and hopefully this will stimulate public participation in the conservation of our natural environment.

We acknowledge the stimulating discussions we have had in workshops during the project with Sigurdur Magnusson, Sven Brakenhielm, Magnus Gaard, Terhi Ryttäri, Martin Zobel, Jesper Fredshavn, Flemming Skov as well as the NMD-group. We also acknowledge the contribution to model development and Internet implementation from a research grant to first author from the Danish Research Councils. 


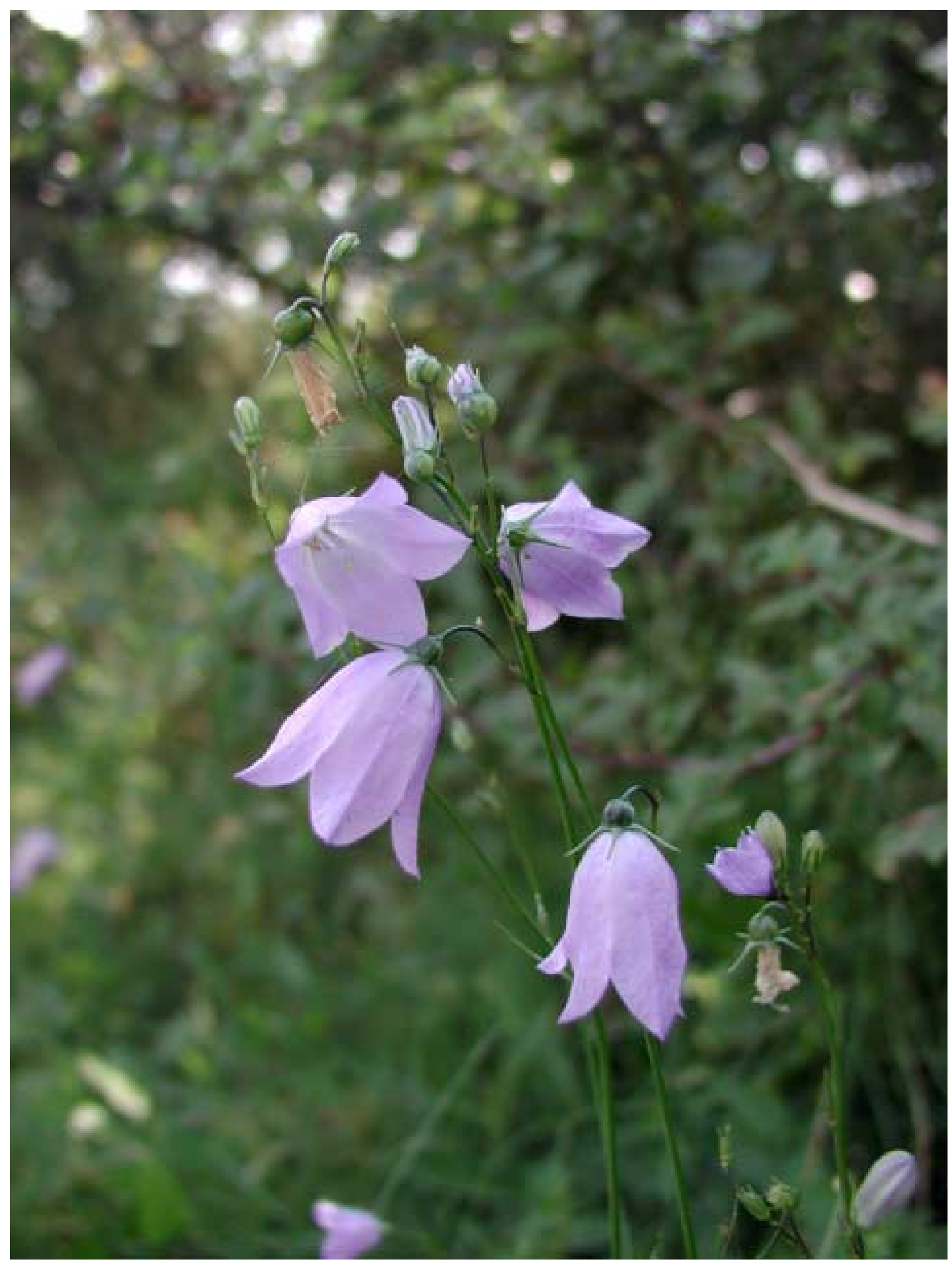

Campanula rotundifolia - a species with declining trend due to eutrophication. Photo: Rasmus Ejrnas 


\section{Summary}

In this report we describe the results of a project aiming at the development of methods for assessment of conservation value in selected Nordic habitat types. We have explored the normative concepts of conservation, and found that consensus about objectives are needed before numerical methods for quality assessments can be developed. In this project we have adopted naturalness as the overall conservation objective, and we describe how this concept is related to other concepts in conservation biology. We also review the criteria for conservation as they have been used in the Nordic countries till now.

A necessary first step in the search for numerical methods is a definition of baselines, i.e. criteria that defines habitats in favourable/optimal conditions in terms of measurable parameters such as species composition, species richness or physical and chemical parameters. Given naturalness as overall objective, reference habitats may be identified and used as baselines for value assessments. We have selected species composition as the most accessible and reliable baseline parameter, and in the report we describe how large reference data sets may be used to delimit a "universe of discourse" within which numeric evaluations can be carried out.

Using this approach, two models have been developed and described. The Habitat Quality Model evaluates the habitat quality of uncultivated open land habitats by passive ordination of samples along gradients in nutrient richness and wetness. This model effectively discriminates between improved grasslands subjected to fertilisation and drainage on one side, and natural or semi-natural grassland, heathland, wetland and dune communities on the other. The Succession Model was developed as a supplement to the Habitat Quality Model, for the discrimination between abandoned infertile fields and heathland and grassland habitats. We report from the statistical and ecological validation of the models and discuss their application in practical management. We also describe how these models have been made accessible to the public through an interactive Internet site. Now the committed user will be able to pass his own species to the models, and obtain an evaluation based on comparison with large data sets otherwise inaccessible to him.

Finally we discuss how the developed models contributes to an information framework for communicating the state of the natural environment to managers, decision-makers and the general public. We emphasise the type of obligations present in the Habitats Directive as they form a case of interest to member countries as well as countries outside the European Community. Finally, we describe and review a supplementary Dutch approach to the aggregation of data for the achievement of simple and intuitive indicators for states and trends of biodiversity. 


\section{Sammendrag}

I denne rapport beskriver vi resultatet af et fireårigt nordisk udviklingsprojekt som har haft til formål at udvikle metoder til vurdering af naturkvalitet i udvalgte nordiske naturtyper. Efter at have begået en udredning af junglen af normative begreber indenfor naturbeskyttelse i teori og praksis, konkluderer vi at konsensus om målsætninger og referencer for høj naturværdi er en forudsætning for udviklingen af numeriske metoder til kvalitetsvurdering. I dette projekt anvender vi naturlighed, på engelsk "naturalness", som overordnet reference for naturkvalitet, og vi beskriver hvordan dette koncept er relateret til andre anvendte koncepter og kriterier for høj naturkvalitet.

Det første skridt i udviklingen af numeriske metoder er definitioner af referencer eller "baselines", det vil sige målbare indikatorer for hvornår naturen har en optimal tilstand - eksempelvis artssammensætning, artsrigdom eller fysisk-kemisk miljø. Vi har i projektet valgt artssammensætningen som den mest tilgængelige og pålidelige indikator for naturlighed, og i rapporten beskriver vi hvordan store datasæt med artslister kan anvendes til at afgrænse den verden som der ønskes foretaget vurderinger i.

Ved at anvende naturlighed som reference og artslister som indikator har vi udviklet to naturkvalitetsmodeller som beskrives i rapporten. Habitatkvalitetsmodellen kan klassificerer artslister fra uopdyrkede, lysåbne naturarealer ved passiv ordination efterfulgt af sammenligning med referencedata. Vurderingen foregår langs gradienter i fugtighed og næringsstatus og modellen er i stand til effektivt at adskille kulturpåvirkede græsmarker og kulturenge fra naturlige plantesamfund som naturgræsland, natureng, mose, hede og klit. Successionsmodellen blev udviklet som det næste skridt i erkendelse af at en stor del af naturen i et kulturlandskab i vore dage består af successionsstadier som er under udvikling fra tidligere opdyrkning mod en mere naturlig tilstand. Successionsmodellen kan således bruges til at adskille næringsfattige, men tidligere dyrkede, marker fra naturgræsland og heder med lang kontinuitet og en mere naturlig vegetation. Vi beskriver hvordan modellerne er udviklet og valideret og diskuterer deres anvendelse. Endelig beskriver vi hvordan modellerne er gjort tilgængelige for brugerne via internetdatabasen DANVEG, så den interesserede selv kan gå på internettet og få sin artsliste klassificeret.

Endelig diskuterer vi hvordan de udviklede modeller passer ind $\mathrm{i}$ informationssamfundet med dets krav om forståelige og pålidelige informationer fra forskningen til befolkning og beslutningstagere. Vi fokuserer på Habitatdirektivets krav, som er interessante både for lande i og udenfor EU, og beskriver hvordan dette projekts resultater kan anvendes. Endelig beskriver og evaluerer vi i lyset af vore resultater et hollandsk koncept for aggregering og vægtning af arts- og arealdata med henblik på udviklingen af letforståelige indikatorer for tilstand og trends i biodiversiteten. 


\section{Samantekt}

Í pessari skýrslu kynnum við niðurstöður fjögurra ára verkefnis en tilgangur pess var að próa aðferðir til að meta náttúruverndargildi valinna norrænna vistgerða. Eftir að hafa kannað fjölmörg stöðluð hugtök sem notuð hafa verið innan náttúruverndar teljum við nauðsynlegt að fyrir liggi sameiginlegur skilningur á pví hvaða pættir gefi ákveðnu fyrirbæri hátt náttúruverndargildi. Að öðrum kosti er ekki unnt að nota tölulegar greiningaraðferðir við slíkt mat. Í verkefninu er hugtakið náttúrleiki (e. naturalness) sett öðrum hugtökum ofar innan náttúruverndar. Við lýsum pví jafnframt hvernig pað tengist öðrum hugtökum í náttúruverndarfræðum. Við gefum einnig yfirlit yfir helstu hugtök tengd náttúruvernd sem hingað til hafa verið notuð á Norðurlöndunum.

Fyrsta skrefið til að próa tölulegar aðferðir við mat á náttúruverndargildi er að skilgreina grunnviðmið, p.e. mælanlega vísa sem segja til um hvenær náttúran er í kjörástandi t.d. hvað varðar tegundasamsetningu, tegundafjölda og ytra umhverfi. Í verkefninu völdum við tegundasamsetningu sem traustan og aðgengilegan vísi um náttúrleika. Í skýrslunni lýsum við einnig hvernig unnt er að nota stór gagnasöfn með tegundalistum til pess að afmarka pau gildi sem meta skal.

Með pví að nota pessa nálgun voru tvö líkön próuð og peim lýst. Vistgæðalíkanið notar tegundalista til pess að meta vistgæði óræktaðra skóglausra vistgerða með óvirkri (e. passive) hnitunargreiningu á sýnum sem tekin eru á næringar- og rakafallanda. Líkanið getur auðveldlega aðgreint graslendi sem breytt hefur verið með áburðargjöf eða framræslu frá náttúrlegu graslendi, mólendi, votlendi og sandhólagróðri. Framvindulíkanið var próað sem viðbót við vistgæðalíkanið til pess að greina aflögð ræktarlönd frá náttúrlegu mólendi- og graslendi. Við lýsum pví hvernig líkönin voru búin til og prófuð og greinum frá pví hvernig unnt er að nota pau í hagnýtum tilgangi. Að lokum er pví lýst hvernig líkönin hafa verið gerð aðgengileg á Netinu með gagnagrunninum DANVEG. Peir sem pess óska geta pví með auðveldum hætti flokkað land eftir sínum eigin tegundalistum.

Að lokum fjöllum við um hvernig líkönin eru fallin til að miðla upplýsingum um ástand náttúrunnar til almennings og til peirra er taka ákvarðanir í samfélaginu. Við beinum athyglinni að peim skuldbindingum sem fram koma í Vistgerðareglugerð Evrópusambandsins og lýsum hvernig nýta má niðurstöður pessa verkefnis í samræmi við pær. Í ljósi niðurstaðna okkar gefum við að lokum yfirlit yfir hollenska aðferð sem nota má til að meta og flokka gögn um tegundir og svæði til að fá upplýsingar um ástand og breytingar á líffræðilegum fjölbreytileika. 


\section{Introduction}

The Convention on Biological Diversity (United Nations 1992) emphasises the importance of global protection of biodiversity, and the EC-Habitats Directive (Anon 1992a) from the same year enforce a protection strategy based on designation, monitoring and protection on the member countries. These initiatives are not new to the Nordic countries having long traditions of nature conservation. New challenges are emerging however, and among these we find an increasing public demand for information about the status and trend of biological diversity on local as well as national scales, and a demand for tools that may facilitate the integration of diversity concerns in agricultural and silvicultural policies.

\section{From concept to standardised methods}

Conservation typically implies a restriction on societal activities, including construction works, agriculture and forestry, and this inevitably leads to conflicts between biological conservation and the legal rights of landowners. These latent conflicts invoke a demand for standardised and scientifically sound methods for prioritisation. The ultimate goal will be to achieve a commonly agreed concept for value assessment that is made operational through the interplay of biological science and statistical modelling. The challenge will be to make use of existing knowledge about biological diversity and its prerequisites in order to inform decision-makers.

\section{Usefulness}

The usefulness of information approaches for biological conservation relies heavily on their demand for data. Practical tools are only practical if the demand for data can be met within reasonable resource limits. Furthermore, the tools developed should be accessible and easy to use, and the outputs or assessment that are derived should be intuitively understandable for the user. We would argue that a certain amount of basic knowledge can be expected from managers that acquire information on the local scale, while laymen, including politicians, that acquire information on the national scale need highly digested results.

\section{Objectives}

- The first objective of this project has been to review existing concepts and issues related to value assessment in biological conservation, and to select a concept on which the development of methods in this project could be based.

- The second objective has been to develop and validate models for assessment of conservation value in selected open land habitats making statistical use of available data.

- The third objective has been to give public access to the developed models through the Internet. 


\section{Outline}

The opening chapter of the report includes a short glossary of terms and concepts in conservation biology. We hope hereby to avoid the pitfall of deliberate and sometimes unwarranted use of ill-defined terms, and at the same time we see this as an opportunity to introduce the "universe of discourse" of the study. We continue in chapter two with a review of criteria for nature quality currently used in local and regional management in the Nordic countries. The redundancy in criteria for value assessment reflects a certain agreement, but perhaps also a certain lack of clarity - the latter indicated by the tendency to include superfluous qualities rather than forget anything.

In chapter three we present the main results of the project, namely the two models for assessment of nature quality in semi-natural and natural open land habitats. The methodological approach is described together with the ecological validation of the models, and the perspectives for wider application of method and models are discussed. In chapter four we discuss how model assessment can be integrated and combined with other information sources from local to national scales in order to achieve national information systems for communication of states and trends.

In chapter five, we describe an Internet implementation of the models, and discuss how this can contribute to the distribution of information about the ecosystems of a region to the public.

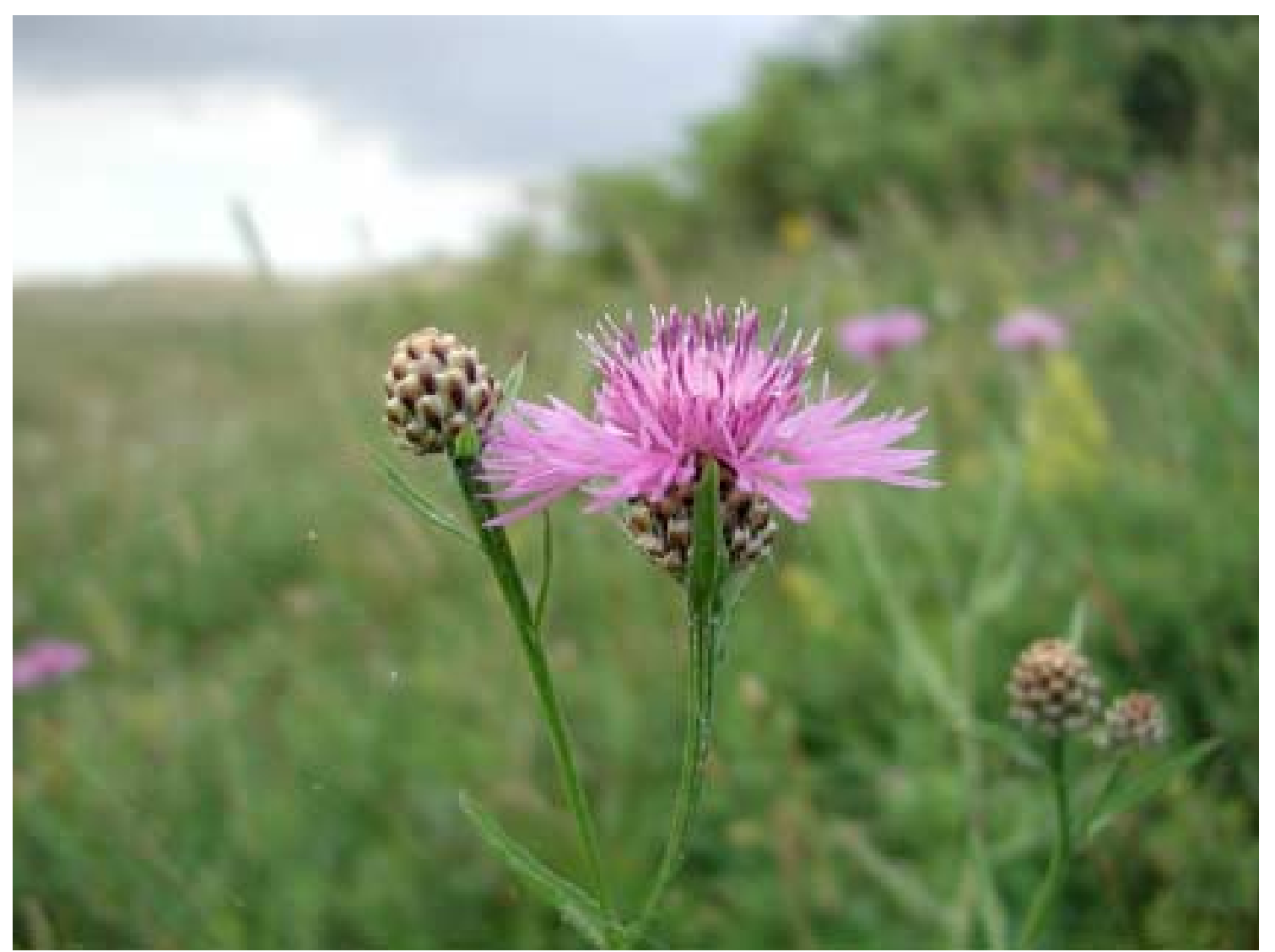

Centaurea jacea, a characteristic forb from semi-natural grasslands. Photo: Rasmus Ejrnas. 


\section{Concepts and issues}

Conservation biology is loaded with normative concepts, and even if these have a clear definition, their use is often unwarranted. Too often, value assessments are carried out without proper reference to concepts and criteria. Following the usual criteria for evaluation of science, conservation could certainly be criticised for its subjectivity. Such criticism may not be fully justified as conservation biology is really exploring the boundary between biological science and political reality, and therefore need to take into account also the subjective values associated with nature. It is often, if not always, these values that motivate the conservation of our natural environment.

A major part of conservation science - the scientific understanding and forecasting of the outcome of interactions between environment and biota - may still be carried out as an objective science, but a precondition for applied research of societal relevance is a formulation of conservation objectives articulated in well-defined concepts. The concepts in current use often refers to opposite or contradictory conceptions of nature and its value, conceptions that may in turn rule the formulation of targets and selection of methods to reach targets. In this chapter, we will present and discuss the vocabulary commonly used to set conservation objectives and evaluate conservation success.

\section{Nature versus culture}

The most important dividing line between schools in conservation biology is defined by the perception of the relation between humans and other living beings.

One school argues that humans because of culture, and technology, its companion, have separated significantly from the rest of nature. This separation is not only metaphysical but has been accompanied by a massive human occupation of land and overexploitation of natural resources. Culture is responsible for the current biodiversity crisis, and consequently the natural imperative of conservation biology is naturalness or biological integrity (Angermeier 2000). This school advocates human humility and respect towards non-human nature.

The opposite school defies a separation of humans and nature. Humans are seen as descendants of and participants in ecosystems, and from this point of view, the imperative of conservation is to guide a sensible and sustainable human use of natural resources (Callicott and Mumford 1997; Callicott et al. 1999; Povilitis 2001).

Callicott et al. (1997; 1999) suggests that these contrasting schools be rooted in two different disciplines of ecology: evolutionary ecology and ecosystem ecology. According to their idea, evolutionary ecologists should be predestined to conceive humans as a destructive species, propelled out of nature by its unnaturally rapid adaptation to and modifications of its environment. Ecosystem ecologists on the other hand think in terms of thermodynamics rather than species and populations. And, although humans also affect ecosystems, the changes are often small and less detrimental than the changes in the biota. Consequently ecosystem ecologists should be more inclined to perceive humans as part of nature. 
Angermeier (2000) on the other hand, suggests that the notion of the place of humans in nature be more profoundly related to the history of human religion and culture. There is a strong tradition of domination of nature in Judeo-Christian beliefs, and the derived notion of human superiority still prevails in modern management of ecosystems (Angermeier 2000). Seen in this perspective, the different perceptions may be interpreted as conflicting paradigms rooted deeply in historical and religious beliefs. Such an interpretation may be supported by the recurrent intense and often emotional debate over the subject (Callicott et al. 1999; Willers 2000; Povilitis 2001; Angermeier 2001; Ejrnæs et al. 2002b).

Despite the obvious disagreements about the naturalness of humans and human actions, Angermeier (2001), in a reply to Povilitis (2001), argue that this is of subordinate importance to conservation priorities. Of primary importance is the respect that humans have for non-human nature (Taylor 1981). Without a deep respect for nature, either view of the human-nature relationship can justify ecological behaviour that diminishes integrity and diversity.

\section{A conservation vocabulary}

Biological diversity means:
...the variability among living organisms from all sources including, inter alia, terrestrial, marine and other aquatic ecosystems and the ecological complexes of which they are part; this includes diversity within species, between species and of ecosystems. (Convention on Biological Diversity 2002)

Although the convention text provides a definition of diversity, the use of the concept in management and decision making is not straightforward. It is fairly easy to quantify the species richness, i.e. the number of species, from a well-known taxonomic group within a small area. But such a figure not only ignores most of the species (belonging to other groups) of that area, it also ignores the scale-dependence of diversity. On small spatial scales, species richness may be referred to as $\alpha$-diversity (Whittaker 1972). $\alpha$ diversity basically reflects the number of species that 1) has reached the investigated spot, 2) may potentially live under the environmental regime and 3) can co-exist there, under the current intensity of competition. Obviously, diversity depends on processes such as migration, speciation and competitive exclusion - processes working on very different temporal scales (Zobel 1997). Naturally, the $\alpha$-diversity of an area varies greatly, and is often a poor predictor of conservation value (Angermeier and Karr 1994). On spatial scales large enough to include different habitat types, species richness is referred to as $\beta$-diversity. $\beta$-diversity is synonymous to species turn-over, and describes the ecological variability of an area. Again, one may imagine areas where humans have created a heterogeneous environment with high $\beta$-diversity. Such areas may be species-rich, but they are typically copied all over the world and inhabited by the same common set of opportunistic species and have low conservation value. The largest spatial scale is the globe, but even at smaller scales than that, i.e. regional or national scales, species richness transforms to $\gamma$-diversity. At such large scales, the occurrence of rare natural elements, whether ecosystems, habitats or species, stand out as crucially important for biodiversity. 


\section{Naturalness and integrity}

Naturalness can be defined in the following ways:

A thing is natural if it is not made or influenced by humans, especially by human technology (Angermeier 2000).

The way an ecosystem would have functioned in the absence of humans (Anderson 1991).

The definition of Angermeier (2000) is slightly different from that of Anderson (1991) as it does not imply that humans are inherently unnatural. Childbirth without intervention for instance, is considered natural. Angermeier argues that technology is what distinguishes humans from the rest of the biosphere, the reason why humans have succeeded to exert a global domination of land, water, biogeochemical cycles, energy and other species (Vitousek et al. 1997). Human activities therefore compromise the naturalness of our environment when they involve culturally developed skills and technology. In practice, this is almost always the case.

Naturalness is not an absolute concept, but may be used as a relative measure of nature quality along a gradient from pristine ecosystems to highly modified agricultural fields or urban areas (Anderson 1991). Anderson (1991) suggests three ways of assessing naturalness:

1) The degree to which a system would change if humans were removed from the scene;

2) The amount of cultural energy required to maintain the functioning of the ecosystem as it currently exists;

3) The complement of native species currently in an area compared with the suite of species in that area prior to settlement.

According to Anderson (1991), the first criterion is hypothetical, whereas the other two may be developed into measurable indices for quantification of naturalness.

Naturalness is closely related to the term biological integrity defined by Karr \& Dudley (1981) as:

"ability of an ecosystem to support and maintain a balanced, integrated adaptive community of organisms having a species composition, diversity and functional organisation comparable to that of a natural habitat of a region"

As Karr (1993) pointed out, ecological integrity may be seen as the sum of physical, chemical and biological integrity. For a long period, chemical integrity was the target of monitoring and management in aquatic ecosystems of Europe and USA - based on the notion that pollution with organic wastewater and inorganic nutrients constituted the major threat to water quality (Barbour et al. 2000). Recently, it has been widely acknowledged that reaching chemical integrity will not prevent the continuing degradation of biological diversity and indicators of biological integrity are now being included in monitoring of freshwater habitats (Barbour et al. 2000).

The use of naturalness and integrity parallels the use of the term nature quality as defined by Nygaard et al. (1999) and Mark (2001). Common to these terms is that they value the intrinsic values of our natural environment. From this perspective nature have 
inherent values that escape an evaluation focussing solely on the importance of nature for sustaining human lives.

Nygaard et al. (1999) suggest four criteria that are important components of nature quality, namely wildness, originality, continuity and authenticity. In their use, wildness is the free interplay of environmental forces and biota without human interference. This interplay includes interactions between biota and environment as well as between individuals and species in the environment. Wildness may occur in all ecosystems, also highly artificial ones, but past and present intervention by humans that constrains the natural processes diminishes wildness. Originality values the occurrence of native natural elements (habitats, ecosystems, landscapes, species and genes), and the original is thus what would have been in the absence of human technology. Continuity values the spatial and temporal extent of natural elements of high originality and wildness. The quality of continuity is motivated by the notion that the natural development of ecosystems takes time (i.e. the colonisation of an abandoned arable field by grassland or forest species), and that sufficient space is critical to a number of important wild processes (i.e. interaction between wild herbivores and vegetation). Authenticity values nature as the result of natural processes, and consequently human intervention to reconstruct habitats or reintroduce species is less authentic than restoration by natural succession. Sometimes the criteria for nature quality will point in different directions, thereby reflecting the inevitable dilemmas faced by nature conservation in densely populated cultural landscapes.

Although the definitions of naturalness, nature quality and integrity are clear, it is not always clear how they should be implemented in nature conservation and management. A much-debated subject is whether, or to what extent, humans should interfere with natural processes in attempts to restore naturalness. By definition such interventions compromise naturalness (Angermeier 2000). This question has evoked an emotional debate between restorationists (Gunn 1991), who see restoration as an ethical imperative for humans, and anti-restorationists (Elliot 1994), who question the value and authenticity of human constructions of nature. Between these extreme standpoints, we find conservationists arguing that under some circumstances the gain in naturalness following intervention may be higher than the loss (Angermeier 2000).

Practical measurement of naturalness in existing habitats or ecosystems relies on operative descriptions of reference condition, and the value of naturalness as a useful concept has been questioned given the difficulties of defining such natural benchmarks (Callicott et al. 1999). Angermeier (2000) admits the scientific challenge in establishing sensible benchmarks, yet defends the usefulness of the concept.

\section{Sustainability}

Ecological sustainability and ecosystem health are presented as alternative targets for conservation and management of our natural resources (Callicott et al. 1999). They are inherited from the concept of sustainable development and the notions of ecosystem services and ecosystem functioning (Callicott et al. 1999). Ecosystem health is defined as:

The occurrence of normal ecosystem processes and functions. Accordingly, ecosystems are healthy when the linked ecological processes that compose them occur 
normally, that is as they occurred historically (Costanza et al. 1997).

The opposite of ecosystem health, ecosystem distress syndrome, may be indicated by e.g. leaching of nutrients, accumulation of nutrients in aquatic ecosystems or changes in primary productivity. The motivation for the conservation of ecosystem health is the value to human life of ecosystem services, including e.g. nutrient cycling, nitrogen fixation and pollination (Costanza et al. 1997). In this way, the values promoted by ecosystem health may be seen as instrumental as opposed to intrinsic. Ecological sustainability implies an economic and social development without compromising ecosystem health. Callicott et al. (1999) argue, that whereas naturalness may be an appropriate target for the management of nature reserves, ecosystem health is more appropriate when dealing with the majority of land exploited by human populations. Contrary to this, Angermeier (2000) argues that naturalness may be used as guiding principle along the continuum between the entirely natural and entirely artificial condition.

\section{The Nature quality concept of this project}

Naturalness has been adopted as the nature quality concept of the current project. We do acknowledge that nature conservation in densely populated and heavily impacted landscapes must involve thinking in terms of sustainability, i.e. the balanced prioritisation of social, economic and environmental concern. But we find that naturalness is the most convincing concept for defining the concerns related to biological conservation. Obviously nature management in cultural landscape need to take into account the present state of landscapes and ecosystems, including the current amount of habitat loss and the absence of keystone species and natural dynamics. This means that although naturalness may be appropriate as baseline and for selecting criteria for value assessment, compromises and pragmatic solutions will often be needed when it comes to practical management for conservation. Hopefully, the advantages and limitations of naturalness as objective for biological conservation will emerge clearly through the following chapters. 


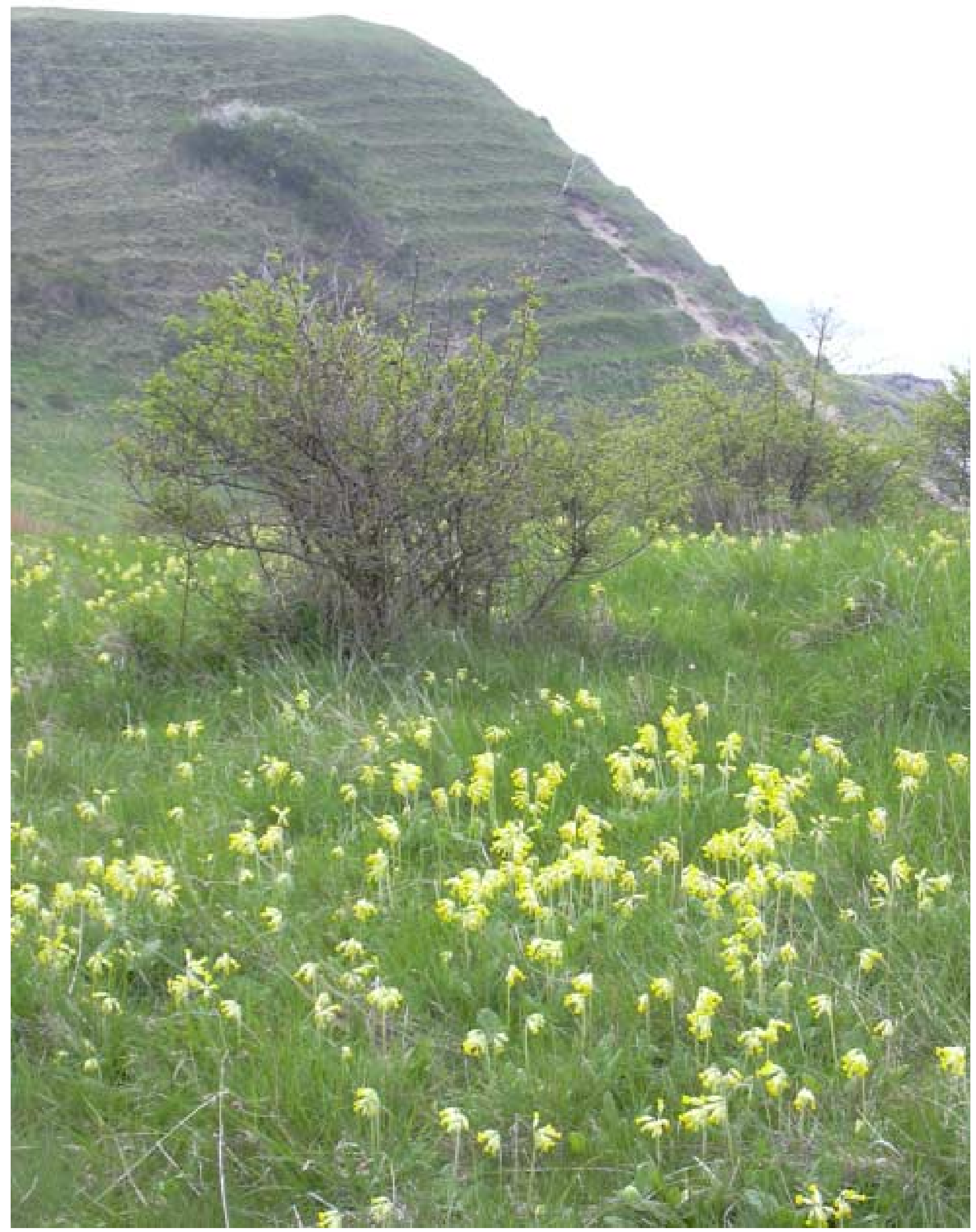

Calcareous grassland with Primula veris, Helgences, Denmark. Photo: Rasmus Ejrnas 


\section{Criteria for value assessment}

Nature conservation has a long tradition in the Nordic countries. In the late 19th century nature conservationist were influenced by national romantic thoughts. Their primary concern was the protection of untouched nature such as large pristine mountain areas, virgin forest and beautiful scenic landscapes. In Sweden and Finland Nordenskjöld was an early proponent of preserving typical nature types, and his promotion led to establishment of national parks in Sweden and Finland. In Sweden nine national parks were established in 1909, the first in Europe. In Finland similar ideas about nature conservation was established late in the 19th century, and the first national park was established in 1914. In Norway the first national park was not established before 1962, but several smaller areas was protected from the beginning of the 19th century and onwards. In Norway, the increasing demand for hydroelectric power provoked an increasing concern for the protection of major streams and waterfalls. During the 20th century ecological theory became increasingly important in value assessment of nature, and around 1970 conservation programs for several main nature types was initiated. A similar development has occurred in Sweden. In connection with these programs a discussion of evaluation criteria for nature conservation has emerged (e.g. Moen 1973, NOU 1983, Nilsson 1984). Several criteria were introduced, aiming at covering all aspects of conservation value, although some were claimed to be more important than others. The use of such criteria is important for comparing the natural value of different areas, and for establishing a sound basis for public discussions about the need for, and objectives of, nature conservation.

Examples of criteria used in the Nordic countries are given in table 1. As reflected in the table there has been a change in criteria towards more emphasis on continuity, indicator species (and red listed species), and structural elements such as large trees, or old trees.

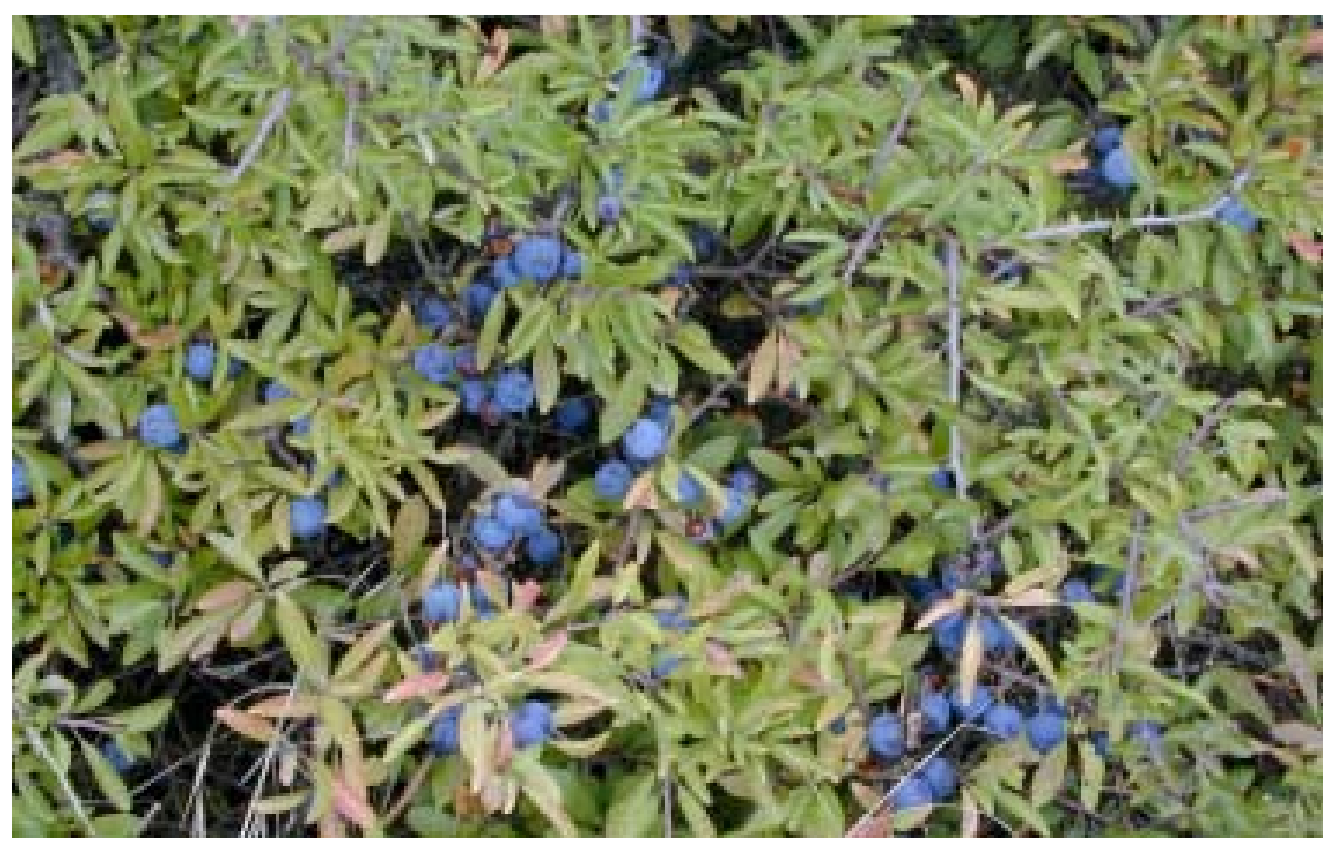

Prunus spinosa. Photo: Rasmus Ejrnaes 
Table 1. Criteria for evaluation of conservation value from selected publications in the Nordic countries. Column letters refer to: A - NOU (1983), B-Nilsson (1984), CClemmensen (2002), D - Haugset et al. (1998), E - Löfgren \& Andersson (2000).

\begin{tabular}{|c|c|c|c|c|c|}
\hline Criteria & $\mathrm{A}$ & $\mathrm{B}$ & $\mathrm{C}$ & $\mathrm{D}$ & $E$ \\
\hline Diversity $^{1}$ & $\mathrm{X}$ & $\mathrm{X}$ & $\mathrm{X}$ & $\overline{X^{2}}$ & $\bar{X}$ \\
\hline Rarity & $\mathrm{X}$ & $\mathrm{X}$ & $\mathrm{X}$ & & $\mathrm{X}$ \\
\hline Naturalness & $\mathrm{X}$ & $\mathrm{X}$ & $\mathrm{X}$ & $\mathrm{X}$ & \\
\hline Area & $\mathrm{X}$ & $\mathrm{X}$ & $\mathrm{X}$ & $\bar{X}$ & $\mathrm{X}$ \\
\hline Landscape ecological considerations & $\mathrm{X}$ & & $\mathrm{X}$ & $\mathrm{X}$ & $\mathrm{X}$ \\
\hline Threat/Vulnerability & $\mathrm{X}$ & & & & \\
\hline Representativity & $\mathrm{X}$ & $\mathrm{X}$ & $\mathrm{X}$ & & $\mathrm{X}$ \\
\hline Function & $\mathrm{X}$ & $\mathrm{X}$ & & & \\
\hline Productivity & $\mathrm{X}$ & & & $\bar{X}$ & \\
\hline Scientific investment ${ }^{2}$ & $\mathrm{X}$ & $\mathrm{X}$ & & & $\mathrm{X}$ \\
\hline Key area & $\mathrm{X}$ & & & & \\
\hline Research $^{3}$ & $\mathrm{X}$ & $\mathrm{X}$ & & & $\mathrm{X}$ \\
\hline Education & $\mathrm{X}$ & $\mathrm{X}$ & & & $\mathrm{X}$ \\
\hline Recreation & & & & & $\mathrm{X}$ \\
\hline Landscape scenery & & & & & $\mathrm{X}$ \\
\hline Genetic resources & & $\mathrm{X}$ & & & $\mathrm{X}$ \\
\hline Potential of remaining high conservation values in the future & & $\mathrm{X}$ & & & $\mathrm{X}$ \\
\hline Potential in the future & & & & & $\mathrm{X}$ \\
\hline Uniqueness & & & & & $\mathrm{X}$ \\
\hline Originality & & & $\mathrm{X}$ & & \\
\hline Wildness & & & $\mathrm{X}$ & & \\
\hline Continuity & & & $\mathrm{X}$ & $\mathrm{X}$ & $\mathrm{X}$ \\
\hline Authenticity & & & $\mathrm{X}$ & & \\
\hline Age, successional stage ${ }^{4}$ & & & & $\mathrm{X}$ & $\mathrm{X}$ \\
\hline Dead wood & & & & $\bar{X}$ & $\mathrm{X}$ \\
\hline Large trees & & & & & $\mathrm{X}$ \\
\hline Indicator species & & & & $\mathrm{X}$ & $\mathrm{X}$ \\
\hline Cultural history & & & & & $\mathrm{X}$ \\
\hline Identity & & & & & $\mathrm{X}$ \\
\hline
\end{tabular}

\footnotetext{
${ }^{1}$ Includes diversity of genes, species, nature types and structural elements.

2 Includes "classic localities" known and investigated for long time.

${ }^{3}$ Includes areas well suited to understand present or former conditions or processes, key areas for scientific understanding.

${ }^{4}$ Includes age of trees.
} 
It is obvious from the criteria in table 1 that although many plans contain specially designed criteria, a common set of criteria are repeated in many conservation plans. The criteria are partially redundant, probably reflecting that the decision-makers were more eager to develop a set of criteria covering all possible situations than a short list for operational comparison.

Some of the criteria are used more often than others (see also Margules \& Usher 1981). In an assessment of criteria used in geological conservation, Erikstad discriminated between primary and secondary criteria, recognising naturalness, diversity, rarity, representativity and function ("part of a system") as primary criteria, as they are more connected to intrinsic properties of the object. The remaining criteria are more connected to how we experience the object from a scientific, educational or recreational point of view. Secondary criteria, such as importance to research, education, recreation and intrinsic value, are very often applied in Nordic conservation programs, as in other parts of Europe. They are relevant, especially in the political process of determination of objectives and priorities in conservation, but they are not in focus in this report.

In the following we will discuss the primary criteria in more detail. In our opinion, the concept of vulnerability needs special attention. While vulnerability is not necessarily connected to nature value, it may be seen as a means for securing cost-effectiveness in management. Therefore, also this concept will be evaluated further below.

\section{Naturalness}

The concept of naturalness is often used in a sense that implies freedom from human influence (Margules \& Usher 1981). In the traditional nature protection movement in the western civilisation this seems to be one of the most important aspects: the steadily increasing use of land for economical purposes triggered the need for conserving pristine areas from such activities. The dominating underlying reasons for using the criterion probably originated from aesthetic, ethical and recreational considerations. A more fundamental scientific rationale lies in the need for maintaining intact ecosystems for comparisons with areas being more influenced by human activity.

The rationale behind naturalness as a conservation criterion is that most humans appreciate the experience of unmanipulated ecosystems more than highly artificial ones. As truly natural areas are rare, they may be valued for this reason too. Although the concept of naturalness is easy to understand, and its relevance to conservation is intuitive, it is difficult to define and quantify as discussed in a recent review of the term natural forest (Rolstad et al. 2002). The different definitions of natural forest may serve as an illustration. Realising that most forest are influenced by humans to some degree, natural forest has been used to describe a forest condition close to undisturbed or virgin forests. Thus natural forest is positioned along a continuum of forest conditions from completely natural to highly artificial plantations. FAO (1998) defines natural forest undisturbed by man as: "Forest which shows natural forest dynamics, such as natural tree composition, occurrence of dead wood, natural age structure and natural regeneration processes, the area of which is large enough to maintain its natural characteristics and where there has been no known significant human intervention or where the last significant human intervention was long enough ago to have allowed the natural species composition and processes to have become re-established". Virgin forests may serve as baseline when trying to operationalise the concept of natural forest. However problems arise as virgin forest are absent from large parts of Nordic countries. 
In Denmark natural forest is defined as: "Natural forests originate from the original forest cover, i.e. a forest reproduced naturally. A natural forest is thus a forest which has spontaneously generated itself on the location and which consists of naturally immigrant tree species and strains. Natural forests can be more or less influenced by culture, e.g. by logging or regeneration techniques, but the forests must not have been subject to regeneration by sowing or planting" (Skov- og Naturstyrelsen 1994). This deviates somewhat from definitions commonly applied in the other Nordic countries (Tanninen et al. 1998), where systematic forest management is not allowed. According to Tanninen et al. (1998) a natural forest is spontaneously generated on undisturbed forest land. The forest has long continuity except when naturally expanding; first generation forests are also considered natural. Thus, the Danish definition is broad, allowing for different management operations, probably reflecting that most forests in the Nordic countries are heavily impacted by forestry. The Danish term is thus comparable to the term semi-natural forest, as defined by FAO (1998).

Naturalness seems to be one of the most common criteria for conservation assessments (Margules \& Usher 1981, Smith \& Theberge 1986). Naturalness is also an important conservation value criterion in the Nordic countries (e.g. NOU 1983, Nilsson 1984). The criterion is particularly useful in nature types such as mountain areas, wetlands, mires and forests. Consequently considerable work has been done to identify virgin forest sites, undisturbed mires and mountainous areas more or less free from human installations such as roads and power lines.

However, totally unmodified nature is a rare condition. It is more useful to regard naturalness as a continuous variable, ranging from completely natural (100\% natural) to completely artificial ( $0 \%$ natural). Since few woods are completely natural, and even the most vigorously managed spruce plantations contains some wildlife, all real woods are in some sense semi-natural (say 5-95\% natural). In Denmark, most nature types are exploited by man (Nygaard et al. 1999), as in other parts of southern Scandinavia. Even in remote areas in the Nordic mountains, anthropogenic impact can be traced (Austrheim \& Eriksson 2002).

\section{Evaluating the semi-natural?}

In primary nature types, high conservation value is associated with as little human impact as possible. However, considerable nature quality is also found in semi-natural nature types. The term semi-natural is one of the most widely used yet poorly defined terms. One of the rare definitions were given by Westhoff (1983), to whom the term semi-natural characterise habitats inhabited by native and spontaneously colonising species, yet dependent on traditional management (grazing or hay cutting) to prevent invasion of woody species. It is not clear however from Westhoffs definition, how much human interference can be tolerated before the term semi-natural becomes inappropriate. If the human impact is stopped there will be a succession towards the natural vegetation at the site. Important semi-natural nature types in the Nordic countries are found primarily within the traditional cultural landscape. An evaluation of the status of protected areas in Norway revealed that in approximately $18 \%$ of all areas the conservation values were under threat (DN 1996). Among the most significant threats reported were overgrowing after cessation of traditional agricultural practice and introduction of alien species. Successional processes in semi-natural habitats do not affect naturalness, but may affect continuity, rarity and uniqueness (see below).

Traditional management on the other hand may be seen as compensatory to the apparent 
removal of natural dynamics (fire regime, hydrological dynamics, wind erosion, coastal dynamics, grazing by megaherbivores) by humans in densely populated areas.

The naturalness criterion can also be applied to species. It is generally considered that introduced species has limited conservation value, compared to native species. Native species may be defined as species occurring naturally within a region. This implies that they have immigrated to the region without aid of humans, and that they have selfmaintaining and stable populations, contrary to alien species which may be defined as species occurring outside their known natural range as a result of intentional or accidental dispersal by human activities (UNEP 1995). However, many species now regarded as native has been introduced by man in historic times. This calls for a baseline. Gärdenfors et al. (2001) suggest a starting point in time at A.D. 1800, for the application of the IUCN red list criteria . This year seems somewhat arbitrarily chosen, but it makes the criterion operational. More difficult to handle is the obvious lack of knowledge of exact immigration time of species to a region, meaning that some subjective judgement is unavoidable. Another consideration one must have in mind is that some species may be native in parts of a region but introduced in other parts. Examples are large-leaved lime - Tilia platyphyllos, which is considered native in southeastern Norway, but is introduced and spreading from gardens in other parts, and mossy saxifrage - Saxifraga hypnoides, which is native in the western part of Norway, but is spreading from gardens elsewhere.

There is a gradual change from totally unmodified land to completely artificial land, but the distinction between natural, semi-natural and artificial is hard to define. Recognising that most ecosystems in the Nordic countries are influenced by man to some degree, the difficulty then becomes: "What level of human impact is acceptable?" This certainly will vary between different nature types, perhaps also between different regions. In more intensively used regions of the Nordic countries one may have to relax on the demands of no human interference. Thus naturalness is a criterion that must be applied differently in different nature types. Obviously the degree of acceptable human impact will vary from nature types such as semi-natural grasslands, semi-natural ancient woodland and virgin forests. Consequently the criterion is difficult to apply in seminatural nature types. Primary grasslands in the Nordic countries are found only above the treeline and in flooded areas along rivers and lakes and marine shores. Due to the marked topography, for instance in Norway, open land is also found in screes and steep hills where snow avalanches exclude the establishment of forest. In southern Scandinavia the origin of semi-natural grasslands as a measurable component of the landscape can be traced back to Neolithic times, approximately 6000 BP (Berglund 1991). The development of agricultural land continued through the Iron Age with slashand burn agriculture and clearing of forests. Later on, a permanent farming system with infields and outfields were established. The infields were arable land situated close to the farms while extensive areas in the outfields were used for livestock grazing and fodder production. This traditional farming practise continued until modern agricultural practices developed late in the 19th century. Especially after the Second World War there has been dramatic changes in the cultural landscape, associated with abandonment of marginal sites and intensivated use of the more productive land, including for instance changes in ownership structure and heavy use of artificial fertilisers and pesticides. This has led to an impoverishment of the nature quality associated with the cultural landscape. 


\section{Are the semi-natural of natural origin?}

According to Eriksson et al. (2002) two hypothesises of the origin of semi-natural grasslands in Scandinavia can be distinguished. The traditional view is that a dense forest covered Europe and large parts of the Nordic countries before the development of agriculture in Neolithic times. However, palaeological studies indicate that open vegetation existed in Denmark during Holocene (Odgaard 1994), and most likely this holds true also for other parts of the Nordic countries. The dense-forest-hypothesis has also been questioned by e.g.Vera (2000) and Svenning (2002), who suggested that there was a mosaic of open land, shrub and forest, before semi-natural habitats were created by man. This land mosaic was maintained by large herbivores in combination with edaphic/topographic conditions favouring open land. If this hold true it seems natural that humans in prehistoric times took advantage of these open areas for agricultural purposes. The development of agriculture increased the suitable habitat for species adapted to open land, thereby facilitating open land species to survive and aggregate, leading to a continuous increase of grassland species. These mechanisms lay behind the high species diversity associated with the traditional cultural landscape, which is of primary concern when relating naturalness to semi-natural habitats (Eriksson et al. 2002).

As described above, the nature quality concept of this report is closely related to naturalness. The importance of long continuity has been demonstrated in the discussion above. Long continuity is also regarded as an important property of natural forests. However, young forest successions after large-scale disturbances such as forest fire or wind may also be considered part of a natural system. Long continuity of traditional farming practice is also considered important for cultural landscapes with high nature quality. Continuity may be further divided into continuity of trees, forest cover, dead wood, old trees and large trees (Löfgren \& Andersson 2000). Continuity in natural disturbance regimes such as flooding and fire should also be considered as important aspects of naturalness. Long continuity of traditional management in the cultural landscape, such as pollarding of trees, grazing and mowing is also considered important.

\section{Diversity}

While diversity is an older concept in ecology, the introduction of the term biological diversity, or biodiversity for short, can be traced back to 1980 (Harper \& Hawksworth 1994). The usage of the term has increased tremendously over the last years, especially after the Rio summit, which brought the term into common knowledge to politicians and the public audience. The convention on Biological Diversity defines biodiversity as the variability among living organisms, including diversity within species, between species and of ecosystems (United Nations 2002).

The definition in the Rio Declaration covers every aspect of the world biota, and as such it is not very informative with respect to selection of sites with high conservation value or high quality nature. A closer inspection on the various components of the concept is needed when comparing site quality. Diversity has been used in assessment of conservation value as well as ecological studies long before the Rio summit. It has been referred to as community, habitat or species diversity (Margules \& Usher 1981). Diversity may appear to be a straightforward and easily measured concept. Most people have an intuitive idea of what is meant by diversity, but nevertheless there are no consensus of how it should be defined and measured. Perhaps the reason is that 
diversity has two components. Diversity may refer to the number of different species, the species richness, but also to their relative abundance (Magurran 1988). Whittaker (1972) introduced the concept of alpha, beta, and gamma-diversity, thereby relating diversity to geographical scale. Alpha-diversity is the number of species found in a small homogeneous area, while beta-diversity is the difference in species composition between different sites (or along gradients), the so-called species turnover. Gamma diversity is the total diversity in the area. These concepts are obviously scale-dependent. Noss (1990) offered a hierarchical approach in which structural, compositional and functional diversity are recognised at multiple levels of organisation: genes, species, community and landscapes. His concept has many features in common with the definition of biodiversity from the convention of biological diversity. It was suggested as a guideline for monitoring of biodiversity. By choosing good indicators the approach may also offer some opportunities for site assessment.

\section{Diversity indices}

A variety of indices for measuring diversity have been proposed, of which the Shannon index and the Simpson index are amongst the most popular examples (Magurran 1988). These indices differ primarily in the relative weight assigned to rare and common species (Magurran 1988), which must be accounted for when interpreting the results. In conservation management the maximisation of diversity is often a tempting target as species richness is intuitive and easy to understand. However, as sample size increases, so does the number of species. Great care should therefore be taken when comparing sites if they vary in size. As far as we know, diversity indices have not been used in conservation value assessment in the Nordic countries. Fully justified assessments based on diversity would require complete species lists, covering all known taxa, a requirement impossible to fulfil.

The notion that more diverse sites have a higher conservation value than less diverse sites is appealing to most biologists. However, this is not always true. Species-poor vegetation types may also have a high conservation value. In many cases disturbed or degraded sites, such as clear-felled areas in forests, may actually contain more species than undisturbed areas. Invasive species may add significantly to the diversity, but meanwhile this often implies a simultaneous impoverishment of the native species richness. Richness of a site may be high, but abundance of rare, endemic or endangered species may be low. For this reason there is a need for complementary information of different aspects of biodiversity, species richness or any type diversity index, and species composition.

\section{From species to communities}

Once habitats or communities have been defined within an area it is relatively simple to assess the diversity of the area, in similar ways as with species diversity (Magurran 1988). Classification is a prerequisite of our understanding and structuring of nature. In the case of species there is a long established tradition of taxonomy, which provides a more or less single classification of organisms, at least regarding well studies organisms such as vascular plants and vertebrates. Regarding vegetation types, communities, or habitats the situation become more complex. These terms are seldom precisely defined, but widely used. The existence of distinct vegetation communities remains controversial (Austin \& Smith 1989), and there are methodological difficulties associated with 
defining the boundaries of communities and habitats. Comparing several sites also implies a common understanding and agreement of the classification of objects, a situation not always met.

In the Norwegian conservation programs the classification system is to a varying degree specified. The systems used also vary in detail, from rather wide nature types to vegetation types and phytosociological units. As an example the conservation program for sea birds in Norway only describes the habitats in broad terms, while some forest and coastal vegetation programs has used a rather detailed phytosociological approach.

Regarding vegetation there has been different classification systems in use over time, leading to difficulties when trying to compare them. The classification systems are not complete and are still under development. At the moment the system in Fremstad (1997) is widely used in Norway. Synthesis of vegetation types in the Nordic countries can be found in Påhlsson (1998), and the recent development of DANVEG gives an overview of Danish vegetation types. The EUNIS classification of European habitat types (Davies \& Moss 1999) offers a framework to identify and describe habitats across national borders. However, much work is still needed to agree upon definitions and descriptions of habitats. Nature protection in the European Union has introduced the habitat as a legislative unit with the Habitats Directive. Here Annex II includes a number of protected habitat types deriving from Corine Biotopes Manual. These habitats are selected because they constitute important reservoirs for biodiversity known to be rare and threatened across Europe and they are described based on geomorphology, physical environment and composition of vegetation.

\section{The value of diversity}

Ratcliffe (1977) states that "diversity can be measured as an attribute and as such has neutral value; but because high diversity usually has more interest to biologists than low diversity the actual value measured can be used as a measure of quality in this respect". Diversity is a very common criterion used in assessment of conservation value. In an examination of nine published schemes Margules \& Usher (1981) found diversity to be the most widely used criterion. In a follow up survey this result was even more pronounced (Usher 1986). Similar results are reported by Smith \& Theberge (1986). Species richness is commonly applied also in the Nordic countries (e.g. Nilsson \& Götmark 1992, Klemmensen 2002). Descriptive lists of vegetation types are also commonly applied. Ecological variation was considered important in the Norwegian conservation program for coastal vegetation.

Measures to protect genetic diversity have rarely been used. Most often there has been a belief that by protecting a large representative selection of nature types also genetic diversity is taken care of. However, the genetic diversity of important forest trees was included as a criterion in the conservation program of forests in Norway. Due to the geographic position the Nordic countries have the northernmost occurrences of many habitat-types and species. Borderline and disjunct populations may have important genetic properties and may contribute significantly to the conservation of the overall genetic diversity. 


\section{Rarity}

As with diversity there is no general consensus on how rarity should be defined. Both man-induced and natural factors may contribute to the rarity of a species. Life history traits may explain why certain species never will be abundant. Rarity is often assumed to be related to vulnerability - the more rare a species, the vulnerable will it be to extinction. Therefore rarity is also an important information for classification of species in red-lists. Rabinowitz et al. (1986) introduced a clarifying concept by partitioning the species distribution and abundance into three levels. The species are subdivided according to the geographical area they occupy, their habitat specificity and population size. By combining these three categories one class of common species and seven classes of rarity emerge. Species with wide geographical distribution, wide habitat demands and large population sizes, are common species not particularly vulnerable. Species with small population size and/or narrow habitat demands are more or less vulnerable depending on the intensity and extent of disturbance. Species both with small population size, small geographical distribution and narrow habitat demands are on the other hand very vulnerable to disturbances. Such a classification may serve as a guideline in assessing conservation targets and may facilitate the conservation of rare species. A somewhat similar approach is discussed by Smith \& Theberge (1986), with emphasis on geographic and demographic criteria. They discern five types of rarity. Widespread rare species are species with a wide geographic distribution, but they are scarce wherever they occur. Endemic species have restricted geographic range, while disjunct species have populations separated from the main range of the species. Peripheral populations are at the edge of the species geographical range, and declining species is species previously abundant but now with declining populations.

\section{Scale-dependency}

Such definitions obviously depend on the scale of observation. In Britain, rarity has been defined simply as species occurring in less than 15 squares of $10 x 10 \mathrm{~km}$ (Ratcliffe 1977). Although arbitrary, such a definition may be more useful in practise than more complicated approaches. Similar definitions have not been applied in any Nordic conservation programs, as far as we know. A way of standardising rarity is desirable, but relies heavily on the availability of data of sufficient quality. A quantitative comparison of sites is impossible without high-quality data on species distribution and abundance.

Species may be defined as rare at the local, regional, national or the global scale. Most often rarity is defined with reference to political or administrative borders. In countries with large geographic and biogeographic variation it may be sensible to stratify rarity assessments according to this variation. In most Norwegian conservation programs nationally, regionally and locally rare species are notified, but clear reproducible definitions are not provided. Ecologically important species, endemic species, species showing disjunct distribution patterns or populations at the edge of their geographical range are also often emphasised. More recently there has been increasing focus on redlisted species when assessing nature quality (e.g. DN 1999). In the Swedish woodland key habitat survey the aim was to identify potential habitats suitable for red-listed species (e.g. Norén et al. 2002). Similar approaches have also been implemented in Denmark, Finland and Norway, although in Norwegian forests, with somewhat less emphasis on red-listed species compared to indicator species (e.g. Haugset et al. 1996). 


\section{Rare communities}

Rare vegetation types and habitat types may also be defined and used under the rarity criterion. However, as discussed above, problems with classification, delimitation and lack of data is often encountered. In the absence of land cover data in sufficient detail, large empirical data sets are found, which can be utilised in subjective decisions. This notion forms the basis of a recent compilation of rare and threatened vegetation types in Norway (Fremstad \& Moen 2002), based on empirical data and expert judgements.

The protection of rare species and communities is to many people the most important aspect of conservation. From a philosophical point of view it may be argued that every native species and community within an area have the same value. Non-native and especially invasive species, on the other hand, is regarded as negative or at least neutral to the nature quality of a site.

But rare species are more vulnerable to human changes of the environment. They are more susceptible to catastrophes and accidental events such as habitat alteration or destruction. It may thus be argued that vulnerability (and hence rarity) is an important criterion for site selection, but not for assessment of nature quality.

Next to diversity, rarity is on of the most commonly used criteria when assessing conservation value both in the Nordic countries and elsewhere in the world (Ratcliffe 1977, Margules \& Usher 1981, Smith \& Theberge 1986). In the Nordic conservation programs rarity is always considered, most often in the form of rare species, but also rare vegetation types or habitats (Nilsson 1984, Nilsson \& Götmark 1992, Löfgren \& Andersson 2000, Clemmensen 2002).

\section{Representativity}

When nature reserves are designated, an important goal is the representation within the reserves of the whole range of natural features within the region. Representativity may be thought of as typicalness or inclusiveness (Smith \& Theberge 1986), where inclusiveness means adequate representation of all natural variation in protected areas, while typicalness is related to sites having typical or well-developed natural features in relation to some predefined group of objects. Thus, representativity can be evaluated both with respect to the occurring nature types within a given region, or with respect to regional variation within different nature types. Typical areas may be common and include common species. However, if the full range of ecological variations is to be covered, rare occurrences are also to be included.

Representativy may be seen as a counterbalance to rarity: When applied on a regional scale the representativity criterion ensures that features that are important to the characterisation of that region can be included in conservation plans. Although common to the region, such features may be rare at the global scale. Representativity is also related to diversity: A set of natural areas that are representative on the regional level will have a high total diversity on the national level. However, the criterion does not contain any assumptions with respect to the diversity within single features. Therefore also species-poor habitats such as poor lichen- and dwarf-shrub woodland, oligotrophic lakes or ombrotrophic bogs can be given high priority according to this criterion. Care should be taken not to confound typical areas with trivial sites, at least in site selection for conservation. The choices among several representative sites may be guided by the naturalness criterion. 


\section{Gap Analysis}

The concept of representativity forms the basis of so-called Gap Analysis (Scott \& Jennings 1998), designed to evaluate and inform modern conservation efforts in the United States. Gap Analysis is an assessment of the degree of protection of native animal and plant species achieved by reserve networks. The goal of Gap Analysis is to identify those species and plant communities that are not adequately represented in existing conservation areas. Gap Analysis came out of the realisation that a species-byspecies approach to conservation is not effective because it does not address the continual loss and fragmentation of natural landscapes, and that historically most national parks and other protected areas are selected for reasons other than biological. The method is meant to provide a systematic approach for evaluating the protection afforded biodiversity in given areas. It uses geographic information systems (GIS) to identify "gaps" in biodiversity protection that may be filled by the establishment of new preserves or changes in land-use practices. The main data layers in the analysis are (1) the distribution of actual vegetation types, commonly derived from satellite imagery, (2) land ownership, and (3) the distribution of terrestrial vertebrates as predicted from the distribution of vegetation. The result of the analysis is an evaluation of whether the network of protected areas fulfil the representativity criterion, and an overview of nature types that should be given priority in future conservation planning. The concept of Gap Analysis is applied to all states within the US, and at present it is performed at more detailed geographical scales.

Complementarity analysis may be seen as a development of Gap Analysis. Given knowledge of the total number of species in a set of candidate areas, the analysis gives the lowest number of areas that contains a pre-defined proportion of the total species number for the region in question (Vane-Wright et al. 1991). The conceptual idea is that species richness in the individual candidate areas per se is not a satisfactory measure, because its diversity may be well represented in other areas in the same management plan. Therefore all candidates for the total network of protected areas should be evaluated simultaneously, with the aim of protecting habitats for as many species as possible. Several mathematical algorithms are developed for performing this kind of analysis (Rebelo 1994), and these algorithms may also be used for other biodiversity components than species ("biodiversity surrogates", e.g. vegetation types, land use map units, indicator species etc.). In practical applications, this form of analysis has been based on one single or a few taxonomical groups for which the necessary information exists. Therefore, an important issue is the degree to which areas prioritised for one taxonomic group are congruent with those for another (Pressey et al. 1993), an assumption that is repeatedly criticised (Prendergast et al. 1993, Kotze \& Samways 1999). In addition, although all use of the representativity criterion demands a high degree of knowledge for the area in question, complementarity analysis has been criticised for being especially "data-hungry" (Prendergast et al. 1999). These arguments have been countered by Justus \& Sarkar (2002), who argue that the complementarity algorithms "may be used with very simple easy-to-acquire data sets such as geology maps and climate surfaces, to identify sets of areas that together represent the range of evironments that occur in a region".

Representativity is included in most regional value assessments both in the Nordic countries (NOU 1983, Barskogsutvalget 1988, Nilsson 1984, Löfgren \& Andersson 2000, Clemmensen 2002), as in other parts of the world (Margules \& Usher 1981, Smith \& Theberge 1986). The thematic conservation plans in which different nature 
types are considered separately ensure the inclusion of all these nature types in the total conservation effort. However, the basic classification underlying the thematic plans is an important determinant for the result.

Applications of the representativity criterion presuppose that the nature types under consideration are well investigated. A recommendation is to evaluate further whether the aim of representativity is achieved in different nature types. Nilsson \& Götmark (1992) evaluated the representativity of Swedish conservation areas with respect to nine major landscape and habitat types. They found large differences in the area proportion that was protected, ranging from 1-2\% (farmland and coniferous forests) to $30-32 \%$ (alpine heaths and subalpine birch forests). From these data they concluded that the representation of natural variety in Swedish conservation areas is still inadequate. A recent evaluation of the Norwegian forest conservation program revealed unequal representation of the variation in many forest types and geographical regions (Framstad et al. 2002). In particular forest types in the nemoral, boreonemoral and south boreal vegetation zones is insufficiently protected, as well as low-lying forests in general. In Finland and Sweden the situations seems comparable with insufficient protection of productive forests in southern areas. The main idea of complementarity analysis, viz. to evaluate the whole network of conservation areas as a whole with respect to whether different important "biodiversity surrogates" (e.g. main biogeographic zones and sections) are adequately represented, seems to be a promising way of evaluating representativity.

\section{Vulnerability}

Threat is often used as a criterion for nature conservation (Margules \& Usher 1981, Smith \& Theberge 1986). If a specific area or nature type is especially prone to negative human influence or human activity, it deserves special attention with respect to conservation. In a study of 75 forested lowland nature reserves in Sweden, Emneborg \& Götmark (2000) found that direct threats to the areas (mainly planned clearcuttings) were among the motives for protection in $31(41 \%)$ cases. Their conclusion is that in lowland areas having high productivity (and thereby likely to have conflicts of interest), the degree of threatening may overrule the more intrinsic natural values in the priority list of candidate areas. Thereby, areas of lower value may become protected before more valuable ones (Emneborg \& Götmark 2000).

As this criterion does not pertain to intrinsic properties of the object in question, it may be argued that vulnerability is not a nature criterion. It may therefore be that we should separate between criteria for nature value and criteria for nature conservation, in order to establish a more logical procedure for choosing areas for protection. One of the reasons for this is that not all human activities are necessarily detrimental to the natural area in which the activity is performed: A given nature type can have different vulnerability with respect to different types of human influence. The vulnerability may therefore also to a large extent change over time, due to changes in human demands.

In this we agree with Erikstad (1991), who argues that threat or vulnerability is not a measure of the value of a site. But they are important when protection measures are considered. It is also a very useful concept in Environmental impact assessment (EIA), a process in which the vulnerability can be analysed with respect to specific forms for human impacts. For instance, if the EIA is performed in connection with a new road, the 
vulnerability analysis can be confined to what effect the road will have on biodiversity in the different nature types and topograhic properties that occur within the area.

In figure 1 a practical example of the separation between nature value and nature vulnerability is given. The analysis has two components: A value assessment according to the intrinsic values of the different subareas (fig. 1b), and a vulnerability analysis (fig.1a) relative to the planned impact (for details see Erikstad \& Stabbetorp 2000). This analysis was performed in connection to the planning of a new road through the area; therefore the vulnerability is assessed with respect to how much harm a road will do within the area. It is an important goal for conservationists to participate in area planning so that the inevitable environmental impact arising from e.g. road constructions can be minimised. Such efforts are also important for the ecosystem function in, and the migration between, protected areas. Franklin (1993) stressed that "reserves cannot be the only or even the primary strategy for maintaining biological diversity". The importance of the unprotected areas which surround the nature reserves (coined "the unreserved matrix" by Franklin, 1993) is probably large. It may commonly be the case, as stated for Sweden by Nilsson \& Götmark (1992), that "probably at least half of the species in the country are not represented in protected areas". Scientifically founded use of procedures similar to that of site selection for protection is therefore important also in connection to EIA's.

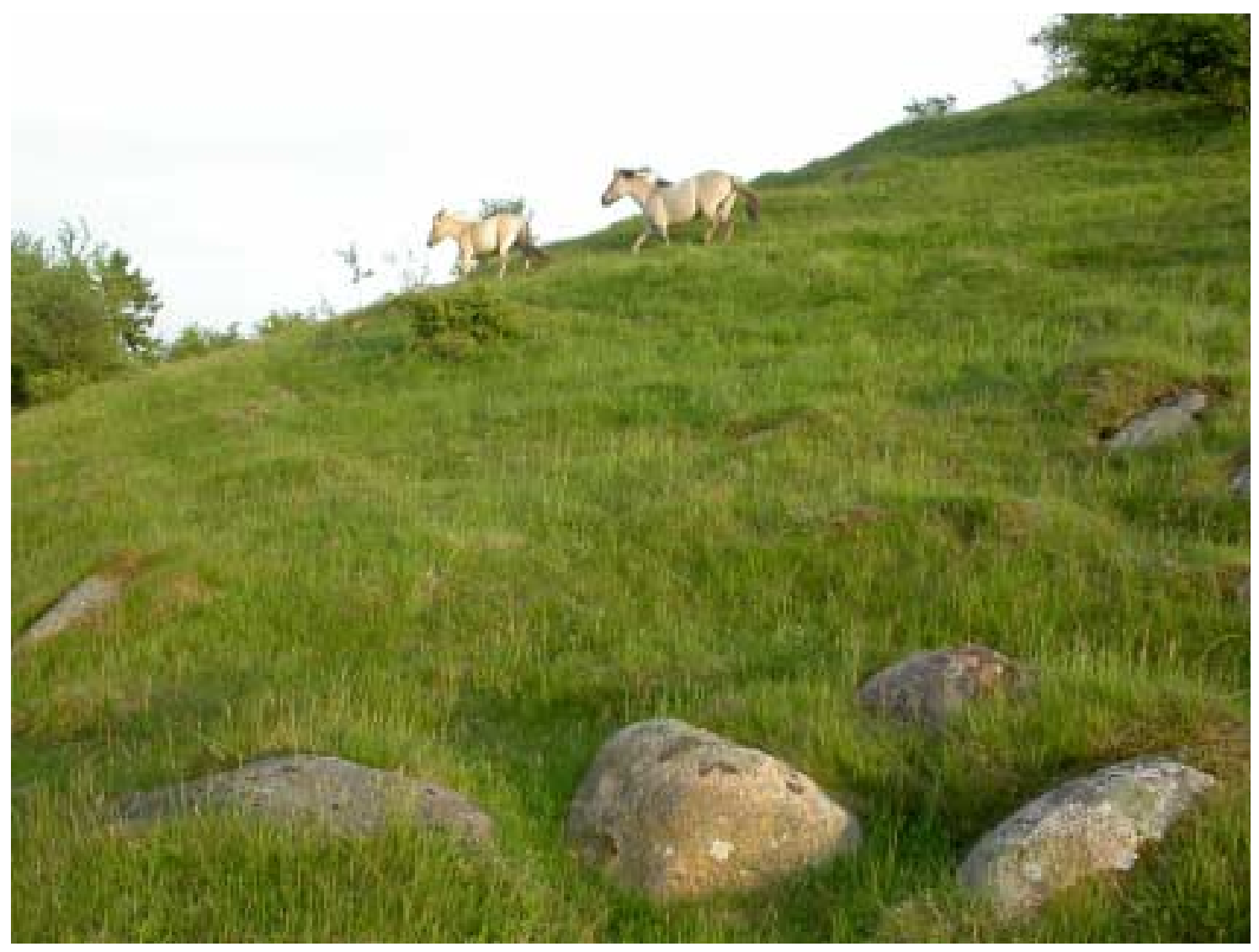

Semi-natural grassland grazed by horses, Mols Bjerge, Denmark. Photo: Roar S. Poulsen. 


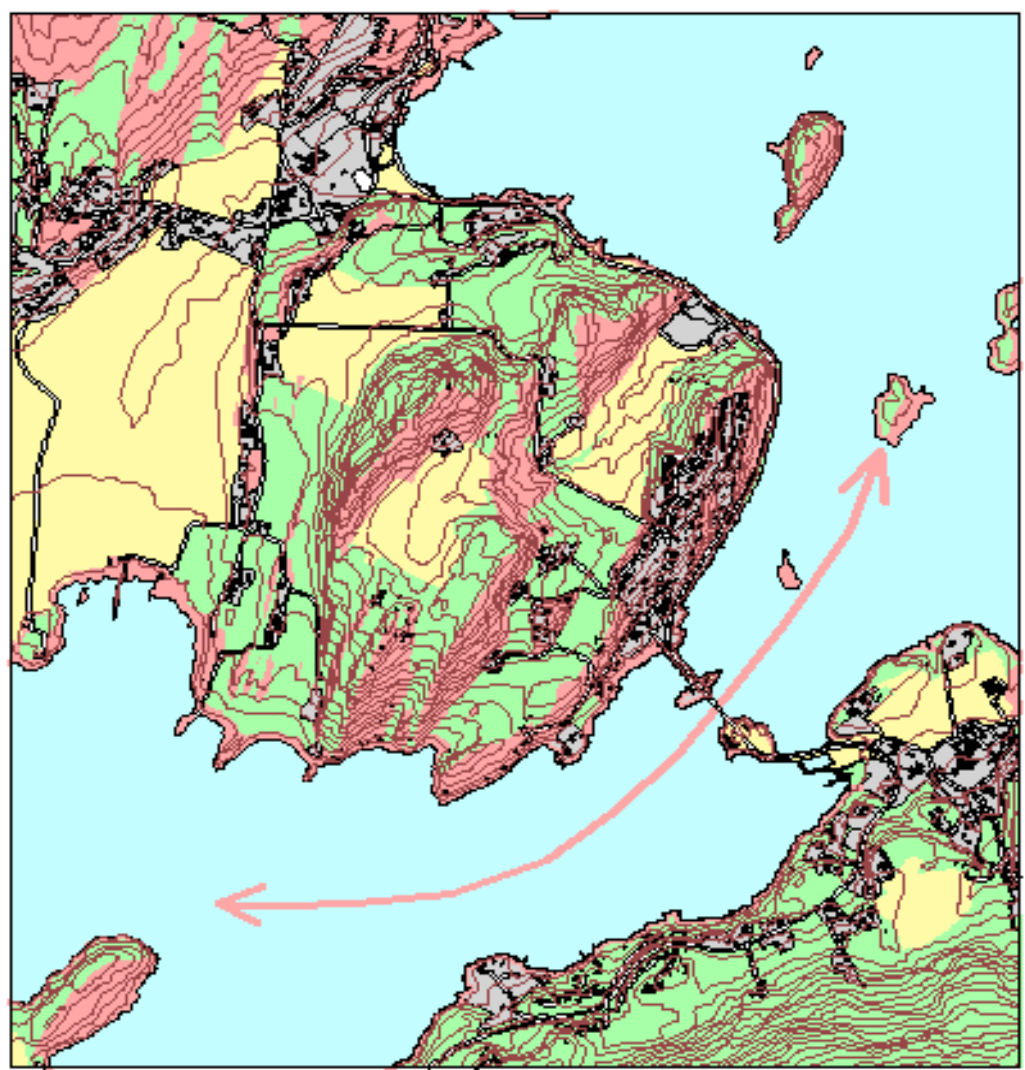

AFige trekk, stor såtiantiet

Bebrgge ise m.m.m.
storsatbanket

in Idde is sárbaribet

L te I så ibarlet

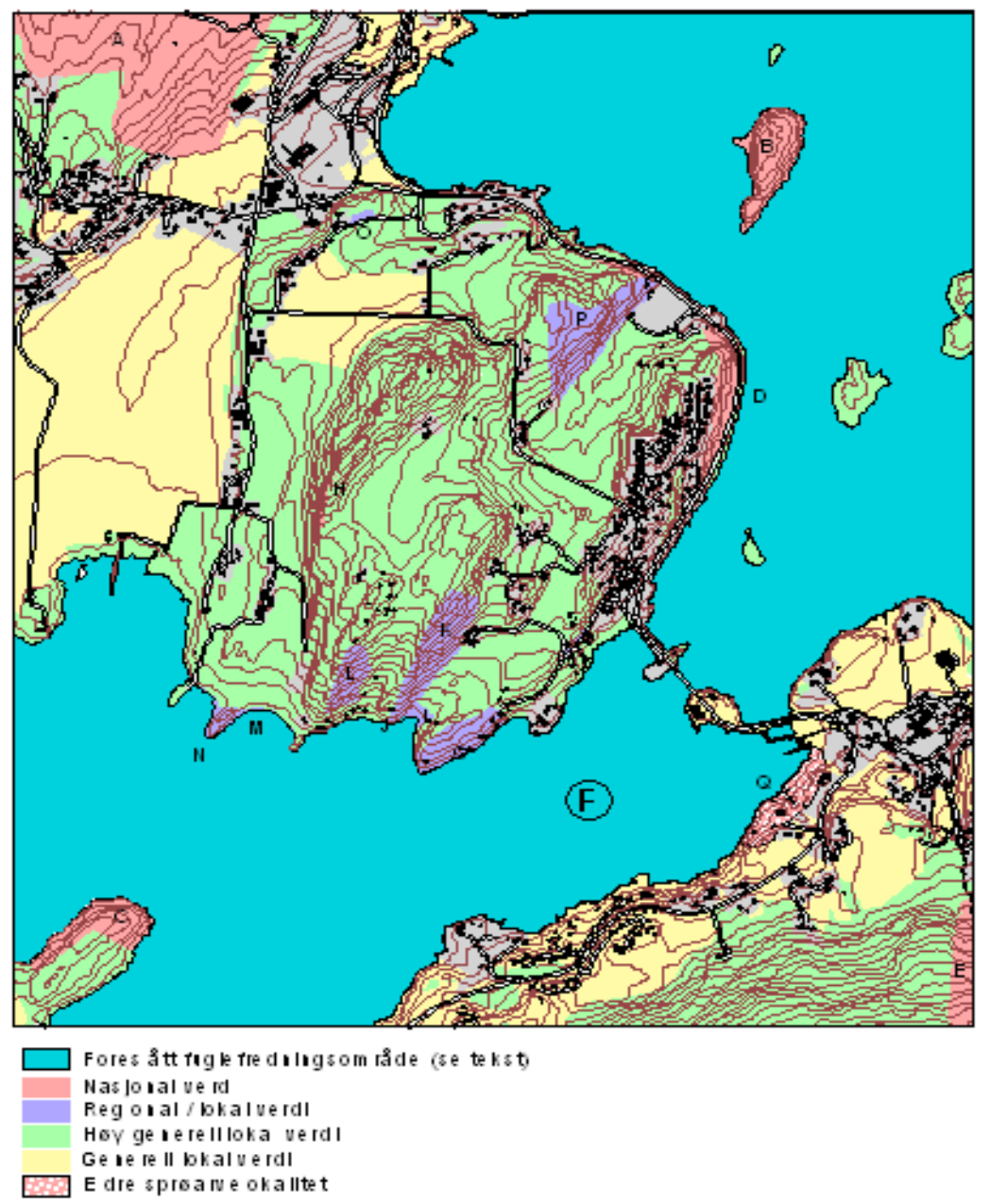

Figure 1. Classifications after: a) Vulnerability, b) Value Refer to textfor more details 


\section{Other criteria}

Size of the area is often applied in conservation programs in the Nordic countries, as in other areas of the world (Margules \& Usher 1981, Smith \& Theberge 1986). Area is related to diversity as the number of species increases with increasing area of a site. Large areas also have a higher diversity of habitats. The relative importance of habitat heterogeneity and area in determining species richness remains unclear as these factors are correlated. Area per se is important, since larger areas provide space for more species to co-exist. Also, a larger area increases the probability of higher environmental variation, thereby habitats for a higher number of species will be present. Large areas allow large-scale natural dynamics to operate, and ensures high variation in different successional stages. Species also differ in their area requirements. Predators require larger areas than their prey and species differ in their ability to disperse and colonise new areas. High conservation values can, however also be associated with small areas, such as small pockets of virgin forests in otherwise managed forest. Area as such should therefore be judged together with other criteria. Size may also refer to large and old trees, which in many cases are considered more preferable than small trees. Veteran trees are an important selection criterion in woodland key habitat surveys in the Nordic countries where they often house rare or highly specialised species. This is also the case in the cultural landscape. Sometimes buffers and boundaries, and the landscape ecological context is taken into considerations in conservation value assessment (Margules \& Usher 1981, NOU 1984, Smith \& Theberge 1986, Löfgren \& Andersson (2000). The rationale behind this is to ensure that the natural values in the protected area will persist in the future and not degrade because of human impact. Edge effects may for instance be damaging to forest interior species, while long edges may be favourable to many species adapted to semi-open areas or animals that use different habitats. Another reason is to account for the different area demands and dispersal abilities of different species. In this respect the size and spatial configuration of the protected areas plays a large part. Shape and connectivity is sometimes considered and also the position in an ecological unit. Complete ecological gradients along seashores were considered important in the conservation program for wetlands and coastal vegetation and in conservation program for mires intact mire complexes were emphasised.

More recently, structural elements believed to be of high importance for species richness or persistence of vulnerable species is considered (e.g. Nitare \& Norén 1992, Haugset et al. 1996, Löfgren \& Andersson 2000, Norén et al 2002). In forests, the amount of dead wood is among the most important elements. It is emphasised that the size of logs and occurrence of different decay stages is important. Occurrence of many small logs cannot compensate for the absence of large-sized logs. For instance grey alder forest will never have logs with large diameters, compared to oak, beech or spruce forests. Large dead logs are important habitat for insects, fungi, mosses and lichens. Other elements often considered are old trees, large trees, deciduous trees in boreal forests, boulders and cliffs. 


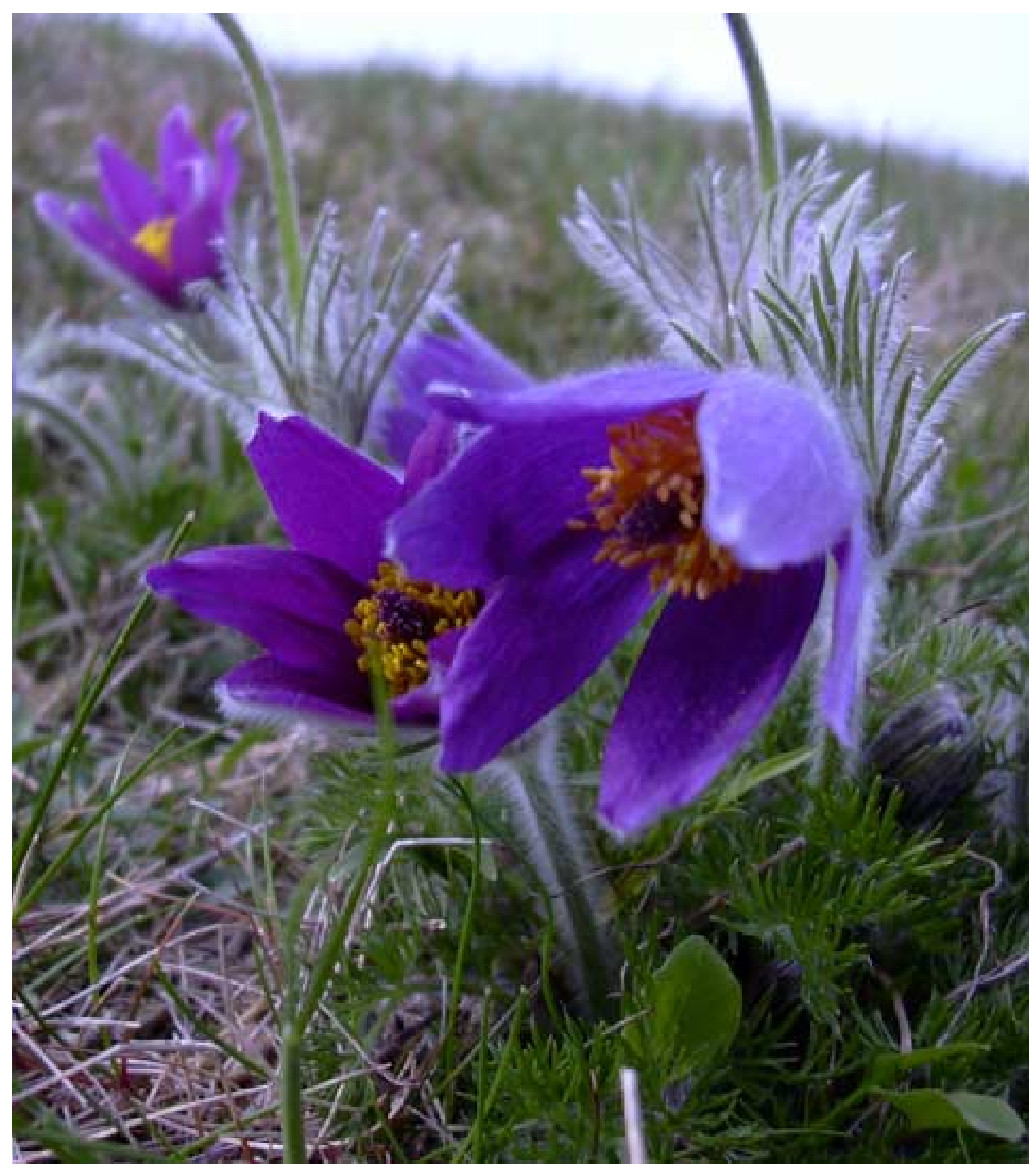

Pulsatilla vulgaris in acidic grassland, Mols Bjerge, Denmark. Photo: Rasmus Ejrnas 


\section{Models for value assessment}

The EC-Habitats Directive gives a nice presentation of the challenge of biodiversity monitoring and evaluation through the concept of favourable conservation status. Favourable conservation status is defined as the fulfilment of three major criteria. According to article 1 (e) of the directive, the conservation status of a natural habitat will be taken as 'favourable' when:

- its natural range and areas it covers within that range are stable or increasing, and

- the specific structure and functions which are necessary for its long-term maintenance exist and are likely to continue to exist for the foreseeable future, and

- the conservation status of its typical species is favourable as defined in (i);

And according to article 1 (i) the conservation status of a species is taken as 'favourable' when:

- $\quad$ population dynamics data on the species concerned indicate that it is maintaining itself on a long-term basis as a viable component of its natural habitats, and

- the natural range of the species is neither being reduced nor is likely to be reduced for the foreseeable future, and

- $\quad$ there is, and will probably continue to be, a sufficiently large habitat to maintain its populations on a long-term basis;

The demands of the Habitats Directive are just an example, and other demands, as they are reflected in national nature protection legislations, could be mentioned. Basically however, they involve the same type of challenge, namely to develop a set of biotic and environmental parameters for defining favourable conservation status and measuring trends in conservation status. A prerequisite for successful monitoring is further that the collection of parameters and the subsequent evaluation of data can be carried out in a standardised and reproducible way.

The objective of the applications presented in this chapter has been to discriminate between open land habitats with favourable conservation status and habitats impacted by human disturbances. We first describe the approach to modelling, and then describe the development as well as the statistical and ecological validation of models.

\section{The evaluation concept}

This chapter deals with the standardised evaluation of species data. In fact the methods may be understood as a statistical extension of the indicator species concept. The indicator species concept is based on the notion that a number of species show clear negative or positive responses to habitats with specific properties of relevance to conservation. Inventories of indicator species could thus serve as a substitution for the assessment of biological diversity through the laborious sampling of a large number of species from different species groups. 
We have developed an extension to this shortcut to assessing the conservation status of the habitat. First, we acknowledge the need for fast inventories excluding species groups that require specialist assistance for sampling or identification. The demand for cost-effective methods also implies that qualitative sampling should be preferred to the more time consuming quantitative methods, whenever these contain sufficient information. Consequently, we work with presence-absence data of vascular plant species. Rather than restricting the indicator concept to a list of selected species, we use the full species list in order to use all available information.

Our approach also differs from the indicator lists in another way. Usually indicator lists seem to naively assume that one list of species may be used to assess the conservation value in a habitat. We rather think that species respond to a number of important environmental gradients, and that these gradients need to be specified. Consequently, the assessment of conservation value will need more than one single method, because the threats to habitat quality usually affect more than one environmental gradient. Indicator-based methods that establish a link to environmental condition are attractive also as they may pinpoint the specific environmental problem to be solved my management.

\section{Reference data}

Our concept is based on establishment of a reference data set that reflects the species composition along relevant environmental gradients. Relevant environmental gradients are defined here as gradients that reflect identified threats to the habitat types in question, e.g. drainage or eutrophication. The reference data set should be large enough to mirror the natural variation in species composition within the geographic area in question along the environmental gradients. Depending on the number of relevant environmental gradients, it may be necessary to establish more than one reference data set.

\section{Species composition}

Species composition is, unlike species richness, not a continuous variable. It is therefore difficult to use raw species data in statistical models. Ordination, i.e. the extraction of floristical gradients - so-called coenoclines, is one solution to this problem (see details below). The variation observed in species data may be divided in generally explainable variation related to common ecological gradients, specific unpredictable or stochastic variation related to unique local events and noise relating to incomplete sampling. Ordination reduces the dimensionality of species data to a low-dimensional space reflecting a major part of the generally explainable variation (Ejrnæs, 2000). It is important to notice that ordination does not reflect species richness, but species composition. This is in many ways an attractive feature, but as we will see in the discussion of perspectives later, it can also be considered a limitation. The coenoclines extracted through ordination come in the form of continuous ordination scores, i.e. sample and/or species coordinates in an n-dimensional space. These scores may be used in statistical modelling. An attractive feature for predictive modelling is that once a reference ordination has been established, the coordinates of new samples may be calculated by passive ordination. 


\section{Training data}

Within each reference data set, a training data set needs to be extracted. The training data set consists of samples that have a defined conservation status, additional to the species information. The information on conservation status may take the form of two or more a priori classes, e.g. "favourable" and "unfavourable" conservation status, or it may take the form of a continuous index value reflecting conservation value. It should be emphasised that the training data set defines the universe of discourse of the model. Reliable assessment of conservation value for data deriving from situations uncovered by the training data cannot be expected. Optimally, part of data is kept as test data for statistical or ecological validation of the model.

\section{The classifier}

The classifier represents a statistical model that predicts the conservation status from the sample coordinates in ordination space. A classifier may be constructed by different statistical methods, and in the case of a training data set with classes, these may be e.g. logistic regression (in cases with only two classes), multinomial regression (more than two classes), discriminant analysis, artificial neural networks or classification trees (Ripley 1996). The classifier is constructed on the training data set, and may be used to predict the conservation status on other data.

A recurrent challenge in statistical modelling is to avoid the over-interpretation of data not least when flexible non-linear or black box methods are used. One way to achieve sensible models is by use of validation techniques - e.g. cross-validation. It is also wise to test the properties of the model on different types of test data asking questions such as:

- Is the model capable of identifying all kinds of habitats with favourable conservation status?

- Is the model correctly identifying all habitats with unfavourable conservation status?

- How robust is the model to sampling method (e.g. plot size)?

\section{Applications}

We will present two applications of such classification models with relevance to Nordic vegetation types. The first model, the Habitat Quality Model (HQ-model), aims at a discrimination between the low habitat quality of drained and improved grasslands, meadows and pastures on one side, and natural and semi-natural dunes, heaths, grasslands, fens, mires and meadows on the other side (Ejrnæs et al. 2002a). The second model, the Succession Model (S-model), aims at discrimination between abandoned fields on one side, and semi-natural grassland and heathland on the other (Ejrnæs et al. submitted).

\section{The habitat quality model}

For the establishment of a reference data set, data representing the present state of the Danish countryside was combined with data from reference-areas representing a minimum of agricultural influence. A training data set was classified into two classes corresponding to low and high influence of agriculture. In Denmark agricultural 
influence on areas outside regular rotation typically implies fertilisation, drainage and irregular episodes of ploughing and reseeding with productive grasses and clover.

Data for the study derive from a landscape inventory in 1998 and from DANVEG, a database of published and unpublished accounts of Danish - mainly natural, and seminatural - terrestrial vegetation (DANVEG 2003, Nygaard et al. 1999).

The 1998-inventory was carried out in 10 transects of $1 \times 5 \mathrm{~km}$, distributed along a regional stratification from naturally fertile eastern Denmark to naturally infertile western Denmark (consult Ejrnæs et al. 2002a for more details).

DANVEG is organised in plant communities derived from a clustering of approximately 9000 vegetation samples. Two subsets of the DANVEG database were selected for the analysis. One subset was selected to represent the variation in semi-natural and natural, open terrestrial plant communities of Denmark (subset $=$ semi-natural). This subset was obtained by random drawing of 10 vegetation samples from all plant communities belonging to dunes, fens, mires, bogs, heathlands and dry grasslands. Salt meadows were not included. Samples without cryptogams were omitted leaving us with 333 samples.

A second subset was defined as samples containing plant species recorded in the Danish red data book (Stolze \& Pihl 1998) now considered as extinct, endangered or vulnerable $($ subset $=$ red-data $)$. Red-data were selected from the remaining samples in DANVEG and samples without cryptogams were included, leaving us with 78 samples containing 23 different red-listed vascular plant species.

The last subset consisted of 9 samples from abandoned fields (subset $=$ abandoned fields) on infertile soils, and was derived from unpublished species lists provided by Frederiksborg County (Unpublished).

\section{A priori classification}

Training data for the artificial neural network consisted of samples recognised as either semi-natural vegetation or agricultural vegetation. Class "semi-natural" was assigned to all samples from subset semi-natural. Class "agricultural" was assigned to those samples from the 1998-inventory having calibrated Ellenberg-values (Ellenberg et al. 1992) indicating ecological conditions outside the range observed for class "seminatural". This was based on the reasoning that fertilisation, and often also drainage have changed the vegetation of agriculturally improved sites.

Ellenberg-values (Ellenberg et al. 1992) are indicator-values describing the ecological optima of a large number of European plant species along ecological gradients (e.g. water and nutrient availability, temperature and light). Environmental calibration based on such species indicator values are used increasingly for ecological interpretation of floristical gradients when environmental data is scarce or missing (e.g. Ejrnæs \& Bruun 2000). Several studies have used environmental calibration for the analysis of vegetation changes associated with atmospheric deposition of acidifying substances and nitrogen (e.g. van Dobben et al. 1999; Lameire et al. 2000).

Calibrations were obtained by averaging Ellenberg-values over all vascular plant species in a sample. In order to select sensible limits for class "agricultural", Ellenbergcalibrations of all samples were used to delimit a section that contained as few representatives of class "semi-natural" as possible. This section corresponded to 
samples with calibrated Ellenberg nitrogen $>5.4$ and Ellenberg humidity $<7.3$. This section contained 3 samples from class "semi-natural" and 334 samples from the 1998inventory. The 334 1998-samples hereafter comprised class "agricultural", and judged from the field notes of the inventory they should be interpreted as agriculturally improved dry grasslands and moist meadows and set aside fields. The remaining 631 samples from the 1998-inventory were saved as test data for model evaluation. Table 2 gives a summary of the data sets used in the study.

Table 2. A summary of the four data sets used in the study and their role in the analysis.

\begin{tabular}{lllr}
\hline Defined subsets & Origin & Role in analysis & \# samples \\
\hline Subset semi-natural & DANVEG & Training & 333 \\
Subset agricultural & 1998-inventory & Training & 334 \\
Test data & 1998-inventory & Testing & 631 \\
Red-data & DANVEG & Evaluation & 78 \\
Abandoned fields & Unpublished data & Evaluation & 9 \\
\hline
\end{tabular}

\section{Ordination}

We used ordination to condense the species matrix into the most important floristical gradients. As recommended (e.g. Minchin 1987, Ejrnæs 2000) we applied two different ordination methods - detrended correspondence analysis (DCA, Hill 1979) and nonmetric multidimensional scaling (NMS, Kruskal 1964). Ordinations were carried out in PC-ORD (McCune \& Mefford 1997). The full data set including training data and test data but excluding red data and abandoned fields was subjected to ordination. To overcome differences in sampling methods, cover and frequency values were transformed to presence-absence. Ordination is known to be sensitive to rare species and species-poor samples, and therefore species with less than 5 occurrences were removed together with plots with less than 5 species. 1283 samples passed these criteria. DCA was run without down-weighting of rare species, with non-linear rescaling and with detrending by 26 segments (default options). NMS was run with percentage similarity as distance measure. The DCA-scores were used as starting configuration for NMS as this produced a solution with lower stress value than 10 random starting configurations. The two-dimensional and three-dimensional solutions were close to each other in final stress and both solutions were included as potential predictor variables in the classification model together with the DCA solution. In order to interpret the ordination axes these were correlated to calibrated site estimates for all 1283 samples.

\section{Neural network modelling}

The classification problem of this study may be seen as a non-linear multiple logistic regression problem. Because we find interactions between our predictors (a gradient in water availability and a gradient in nutrients) very likely, we prefer a classification method that may take into account not only non-linear relationships but also locally 
changing relationships. An artificial neural network $(\mathrm{NN})$ is one possible approach to such a problem (Venables \& Ripley 1997).

The neural network used here is a simple, classical NN. It is composed by: 1) a number of input units corresponding to the number of predictor variables, 2) an optional number of hidden units that each receive numbers from all input units and apply a fixed logistic function to these before passing them to 3 ) an output unit producing the results. The network is tuned by adjusting the weights, which are constants multiplied to the values before they are passed from one unit to another in the network (Venables \& Ripley 1997).

A disadvantage of NN compared to other more traditional statistical models is that the process leading from predictors to results is invisible as it takes place in the hidden layer. For this application the lack of visibility is considered a minor problem. First, we only have 2-3 predictor variables with an expected causal relationship to the response variable. Second, the solution to the classification problem may be visualised and evaluated with a two-dimensional graph. Another claimed disadvantage of NN is the tendency to converge to several locally optimal solutions, depending on the initial weights. Rather than worrying about this, we have chosen to focus on the performance of the best solution reached.

$\mathrm{NN}$ does not differ from other modelling approaches with respect to the risk of overinterpretation of data. In NN the degree of fitting may be decreased by reducing the number of hidden units and the variance of the weights (increasing weight decay) (good examples in Ripley 1996). Values for these parameters were selected based on crossvalidation (see below).

NN was run in S-Plus (Anon. 1999) by the add-in library "nnet" (Venables \& Ripley 1997). Double weight was assigned to observations of class semi-natural as it was considered a more serious mistake if a valuable vegetation sample was predicted to be unimportant than vice-versa.

\section{Cross-validation}

Cross-validation (Venables \& Ripley 1997) was used to choose sensible values for size and weight decay as well as to select the best ordination method (DCA vs. NMS) and the optimal dimensionality (two vs. three ordination axes).

In order to carry out cross-validation, 10 random subsets were drawn from the training data. For each subset, the model was fit to the remaining $9 / 10$ of data and used to predict the class membership of the left-out subset. Hence, model predictions were evaluated by comparison of predicted class (all subsets) with observed class (the a priori classification). This procedure was repeated 4 times with different random subsets and the mean number of wrong predictions was used as test value for the performance of the specific NN.

\section{Prediction and evaluation}

The optimal NN based on the cross-validation was fit to the full training data set. 10 $\mathrm{NN}$-solutions were produced to assess the stability and the best performing solution was accepted as the final NN-classifier. This classifier was used for predicting the value of test data to either class "semi-natural" or class "agricultural". 
Evaluation of the prediction of test data was performed on four selected measures: richness of native species, percentage of native species, occurrence of uncommon species and $\beta$-diversity (Whittaker, 1972).

Subset red-data and subset abandoned fields were used for evaluating the prediction of habitats for red-listed species and young successional habitats and for evaluation of the performance of the classifier when applied to new data. These samples were not included in the initial ordination and so the DCA-scores were first to be determined by passive ordination (Økland 1990) based on the species scores from the existing DCA solution. It should be emphasised that the red-listed species were not present in reference data used for ordination and therefore had no influence on the calculation of sample scores by passive ordination.

\section{Results}

Three ordination solutions were produced - a 3-dimensional DCA, a 3-dimensional NMS, and a 2-dimensional NMS. The three NMS-axes explained 32, 18 and $18 \%$ of the variation in the dissimilarity-matrix (percentage dissimilarity), and corresponding numbers for the 2-dimensional NMS were 36 and $27 \%$. The eigenvalues of the three DCA-axes were $0.76,0.66$ and 0.41 .

The first two axes were readily interpreted by calibrated Ellenberg-values. DCA1 corresponded to a gradient in productivity (Ellenberg nitrogen) and $\mathrm{pH}$ from fertilised grass leys to infertile heathlands and oligotrophic mires, and DCA2 corresponded to a gradient in humidity from dry grasslands to wet fens, mires and bogs. Neither NMS3 nor DCA3 showed strong correlation to any of the calibrated Ellenberg-variables.

We used cross-validation to examine the performance of NN's with nine combinations of a range of settings for size of the hidden layer (2, 3, 4 hidden units) and weight decay $(0.01,0.001,0.0001)$. The experimental range of values for weight decay and number of units in the hidden layer hardly affected the cross-validated misclassification errors. A simple NN, with 2 units and weight decay $=0.001$ performed equally well as any more complicated NN and was therefore selected for the final model. The misclassification error of this model was only $1.1 \%$. The cross-validation experiments further revealed that NN performed better on DCA-scores than on NMS-scores. Inclusion of DCA3 in the model did not improve the cross-validated predictions.

Table 3. Comparison of the two classes semi-natural and agricultural derived from prediction of test data. Species richness, nativeness, samples with uncommon species and $\beta$-diversity are reported as well as statistical tests for class differences.

\begin{tabular}{lllll}
\hline Measure & Test & Semi-natural & Agricultural & Probability \\
\hline $\begin{array}{l}\text { Species richness (native } \\
\text { species) }\end{array}$ & Wilcoxon test & 16.4 & 16.9 & $\mathrm{P}>0.05$ \\
$\begin{array}{l}\text { Percentage of native species } \\
\begin{array}{l}\text { Percentage samples with } \\
\text { semi-rare species }\end{array}\end{array}$ & Wilcoxon test & 93.9 & 84.3 & $\mathrm{P}<0.001$ \\
$\begin{array}{l}\text { C-diversity in 10 random } \\
\text { draws of 40 plots }\end{array}$ & T-test & 12.96 & 9.42 & $\mathrm{P}<0.01$ \\
\hline
\end{tabular}




\section{Evaluation of test data classification}

Figure 2 shows the final HQ-classifier. All plots are shown in ordination space with contour lines indicating the probability of membership to class semi-natural (high quality) as predicted by the HQ-classifier. The plot confirms our initial expectation of a strong relationship between composition of the vegetation and the a priori classification.

Evaluation of the classification of test data (table 3 ) revealed that class semi-natural differed significantly from class agricultural by having a higher percentage of native species, a higher number of plots with semi-rare species and higher $\beta$-diversity. The richness of native species did not differ significantly between the two classes.

The red-data set was subjected to passive ordination using DCA-scores from the ordination. The subsequent classification resulted in all 78 samples containing threatened plant species being classified as semi-natural with a probability $>99 \%$ (Fig. $3)$.

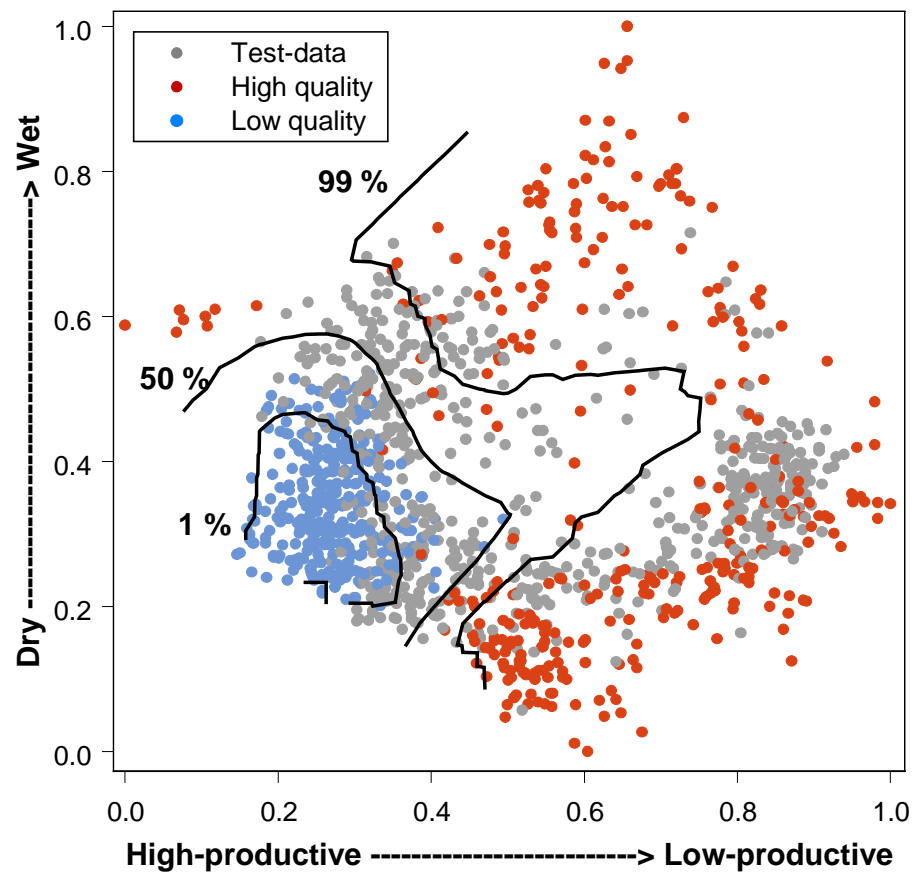

Figure 2. A graph showing the ordination coordinates of training data (high and low quality) and test data. The environmental interpretation are shown for each species composition axis. Contour lines show the three levels of probability of high quality as predicted by the $H Q$ classifier. 


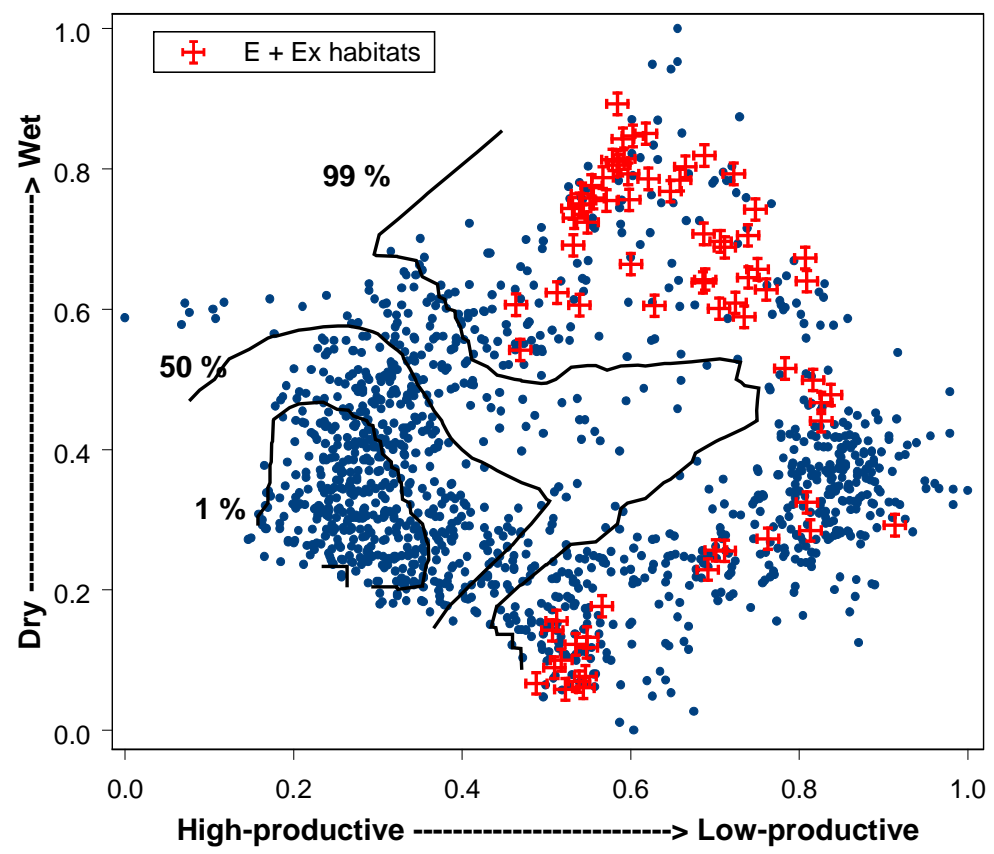

Figure 3. The graph shows the same plots and contour lines as in figure 1 , but in addition the position, within the reference data ordination, of 78 samples with redlisted plant species (endangered and extinct) positioned by passive ordination.

\section{The succession model}

The evaluation so far convinced us that the HQ-classifier would correctly predict samples of high conservation value, and also that we can trust the prediction of samples to have low value. It is important however to look also for false-positives, i.e. samples of low value that are predicted to have high value. The HQ-model predictions are based on vegetation gradients reflecting productivity and hydrology. The most obvious falsepositives would therefore be young phases in the secondary succession of vegetation on disturbed infertile soils, e.g. abandoned fields or gravel pits. To evaluate this hypothesis we used species lists from 9 fields on infertile soils abandoned 25-30 years ago. As seen in figure 4 , these fields were all predicted to have high habitat quality by the model. In fact the abandoned fields are positioned in the cluster of semi-natural grassland plots. Judged from the species lists this is clearly not satisfactory. Although some common grassland species has colonised the fields (e.g. Agrostis capillaris, Hieracium pilosella), the fields are still poor in typical grassland species and contain a large number of species alien to semi-natural grasslands on poor sandy soils. We therefore decided to use available reference data from abandoned fields, collected during the 20th century to develop a model for discrimination between abandoned fields and semi-natural grassland and heathland (Ejrnæs et al. submitted). 


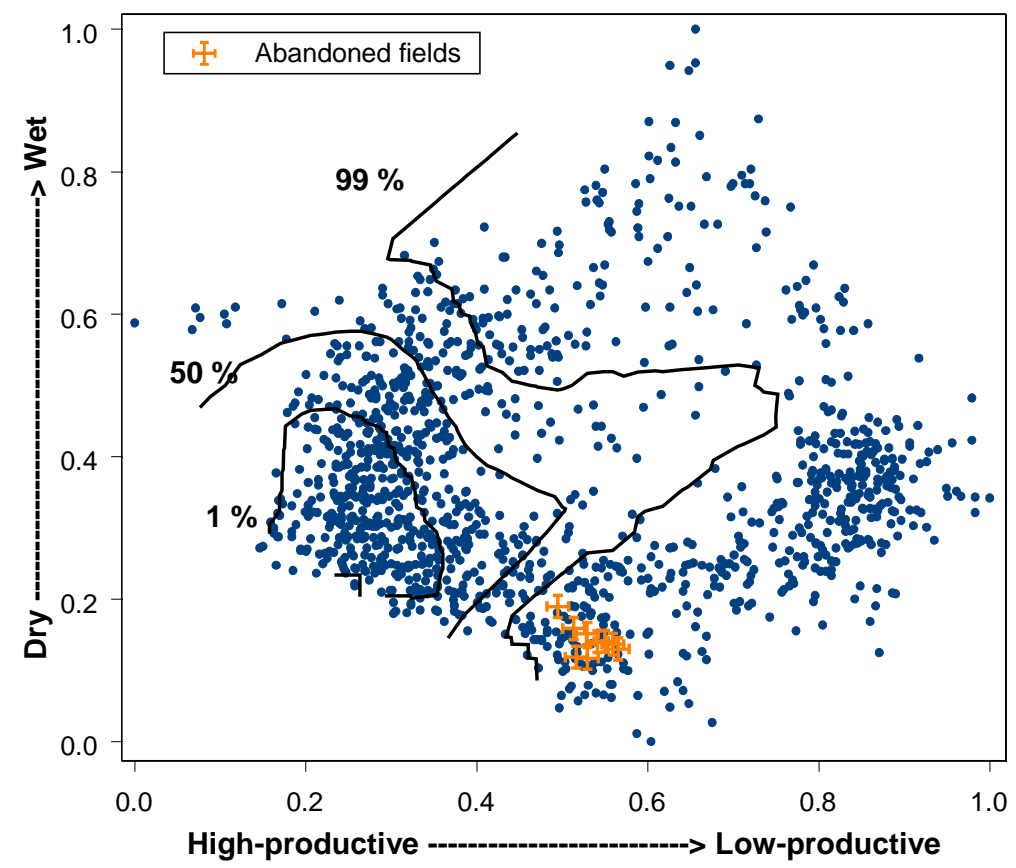

Figure 4. The reference-plot from HQ-model again, but this time with plots from abandoned, infertile fields, placed by passive ordination.

\section{The succession model}

For the succession model, we collected a reference data set consisting of published and unpublished Danish studies of grassland, heathland and abandoned field vegetation. Our criteria for including data were: 1) complete species lists from homogeneous areas, 2) species lists classifiable to either grassland or heathland with long continuity, or abandoned fields and 3) if abandoned fields, years since abandonment should be known. We included 13 data sets, with the majority of studies from 1930-1950, and 1970-2000. Data include 620 samples of old grassland, 904 samples of old heathland and 535 samples of abandoned fields. Although abundance data were collected in some of the studies, and some authors recorded lichens and bryophytes, we decided to use only presence-absence data of vascular plants for this study. The sample plots vary considerably in size from $10 \mathrm{~m} 2$ up to approx. 1 ha. The final data set consisted of 2059 samples and 601 species.

\section{Numerical methods}

Data were a priori classified as "abandoned fields", "old grassland" or "old heathland" and the objective was to predict the a priori classes from information derived from the species lists. We used DCA for ordination. We omitted species with less than three occurrences in the data set prior to ordination but otherwise used default options.

As for the HQ-model, a feed-forward neural network (Venables and Ripley, 1997) was used to find an optimal solution to the classification problem. After parameter selection (selected using cross-validation), we produced $100 \mathrm{NN}$-solutions, and accepted the mean probability of the five best solutions as the prediction. 


\section{Evaluation of classifier}

Besides using prediction error as a measure of classifier performance, we have evaluated the reliability of the S-model by establishing and testing the following four hypotheses regarding model predictions:

1. For abandoned fields, we hypothesise a significant positive relationship between the predicted probability of naturalness and time since abandonment.

2. Considering that agricultural practices have intensified and colonisation sources for grassland and heathland plants have diminished over the last 60 years, we hypothesise that the probability of naturalness have decreased over time.

3. We expect a marked difference in time-span between succession towards heathland and succession towards grassland. A successful colonisation of very few species, mainly heather (Calluna vulgaris), may transform an abandoned field into a functional and structural heathland within few years, whereas a grassland succession implies the colonisation of a larger number of typical species.

4. A considerable part of the abandoned fields would be classified as semi-natural by the HQ-model (Ejrnæs et al., 2002a) because they are infertile. A major part of these will be correctly recognised as abandoned fields by the new S-model. This hypothesis may also be seen as a test of the justification for developing the model.

The first three of these hypotheses were tested using linear modelling of predicted probability of naturalness as a function of successional age, period of abandonment and successional trajectory (succession towards heathland vs. grassland). The predicted probability of naturalness was arcsin-square-root transformed to normalise residuals (Zar 1996). To obtain reasonable abandonment periods, we divided data in three groups: Fields abandoned in the period of 1874-1949, 1949-1969 and 1970-1999. In order to classify the successional trajectory we used the NN-classifier. For each abandoned field, the habitat type with the highest predicted probability defined the trajectory.

Second order interaction terms were allowed in the model, but the third order interaction term proved insignificant in a trial model and was left out of further consideration.

Significance of factors and second order interactions were tested using type III sum of squares (SAS Institute, Inc., 1990).

For testing the fourth expectation, we used the HQ-model (Ejrnæs et al., 2002a) to classify the habitat quality of the abandoned fields and then used the new model to predict the successional phase.

\section{Results}

The first three DCA-axes were used as predictors in the classification model. The optimal NN consisted of one hidden layer with two hidden units, and a weight decay of 0.01 . Table 4 reports the misclassification rate of the mean prediction of the best five NN. The overall misclassification rate was $6.6 \%$. This figure hides important differences between the classes however. The percentage of semi-natural plots misclassified as abandoned fields was generally low. Heathland misclassified as abandoned fields was below $1 \%$ and grasslands between 3 and $4 \%$. The percentage of abandoned fields misclassified as semi-natural was considerably higher. $12.3 \%$ was classified as heathland and $8.4 \%$ as grassland. The cross-validated predictions were very close to the model predictions indicating a reliable degree of fitting by the NN. 
Table 4. Misclassification rates and misclassification score from neural network classification is given in first column and the corresponding cross-validated misclassifications in second column. Row one to four show misclassification errors between class pairs.

\begin{tabular}{lrr}
\hline & Misclassifications & \multicolumn{2}{c}{ Cross-validated misclassifications } \\
\hline Field to grassland & $8.4 \%$ & $9.1 \%$ \\
Field to heathland & $12.3 \%$ & $12.5 \%$ \\
Grassland to field & $3.4 \%$ & $3.3 \%$ \\
Heathland to field & $0.4 \%$ & $0.7 \%$ \\
Overall & $6.6 \%$ & $6.9 \%$ \\
Misclassification score & 187 & 200.8 \\
\hline
\end{tabular}

A discrete clustering in ordination space of our three target classes could cause such a nice discrimination, but this is obviously not the case (fig. 5). Contrary to this, plots disperse continuously along the three DCA-axes, although the bulk of the heathland plots, at the end of the first axis, seem to occupy a more isolated part of the ordination space.

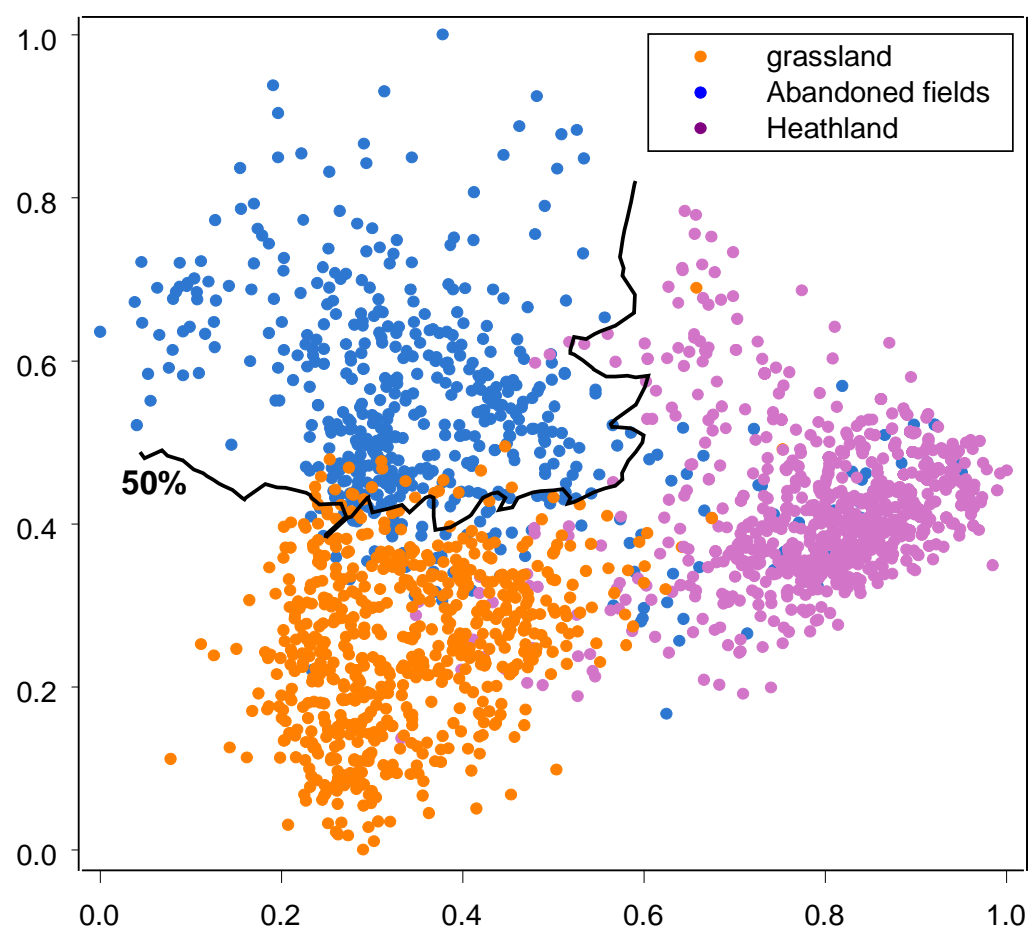

Figure 5. DCA-graph showing the position of the training data set samples of the Succession model and the $50 \%$ contour line of the neural network classifier.

Table 5 shows the results of the modelling carried out in order to test our hypotheses. In agreement with our hypotheses, successional age, abandonment period and succession 
trajectory (grassland versus heathland) all have significant impact on the probability of naturalness. Also, the interactions of trajectory and period as well as the interaction of trajectory and age are significant predictors in the model. The full model has an $\mathrm{r}-$ squared of 0.54 and is highly significant $(\mathrm{p}<0.0001)$.

Table 5. Results from a linear regression model of probability of semi-natural condition as a function of successional age, period of abandonment and successional trajectory. Df is the degrees of freedom, SS is Type III Sum of Squares.

\begin{tabular}{lrrrr}
\hline Variable & Df & SS & F-value & \multicolumn{2}{c}{ P-value } \\
\hline Period & 2 & 6.4 & 50.7 & $<0.0001$ \\
Trajectory & 1 & 1.6 & 25.0 & $<0.0001$ \\
Age & 1 & 0.4 & 6.3 & 0.013 \\
Period * Trajectory & 2 & 8.4 & 66.5 & $<0.0001$ \\
Period * Age & 1 & 0.1 & 0.9 & 0.42 \\
Trajectory * Age & 1 & 1.0 & 15.3 & 0.00011 \\
Residuals & 524 & 33.2 & & \\
\hline
\end{tabular}

Figure 6 visualises the model for prediction of late successional phase. The graphs demonstrate that:

1) The probability of late successional phase increases with age [age significant in table 5].

2) The probability has decreased dramatically from the beginning to the end of the 20th century, especially for heathland successions [period and period $\mathrm{x}$ trajectory significant in table 5].

3) Heathland successions, especially in the early period, are more likely to reach seminatural condition than grassland succession [trajectory and trajectory x period significant in table 5], and typically reach late successional phase much earlier [trajectory $\mathrm{x}$ age in table 5].

The considerable variation in probability along the regression lines should be emphasised too. 


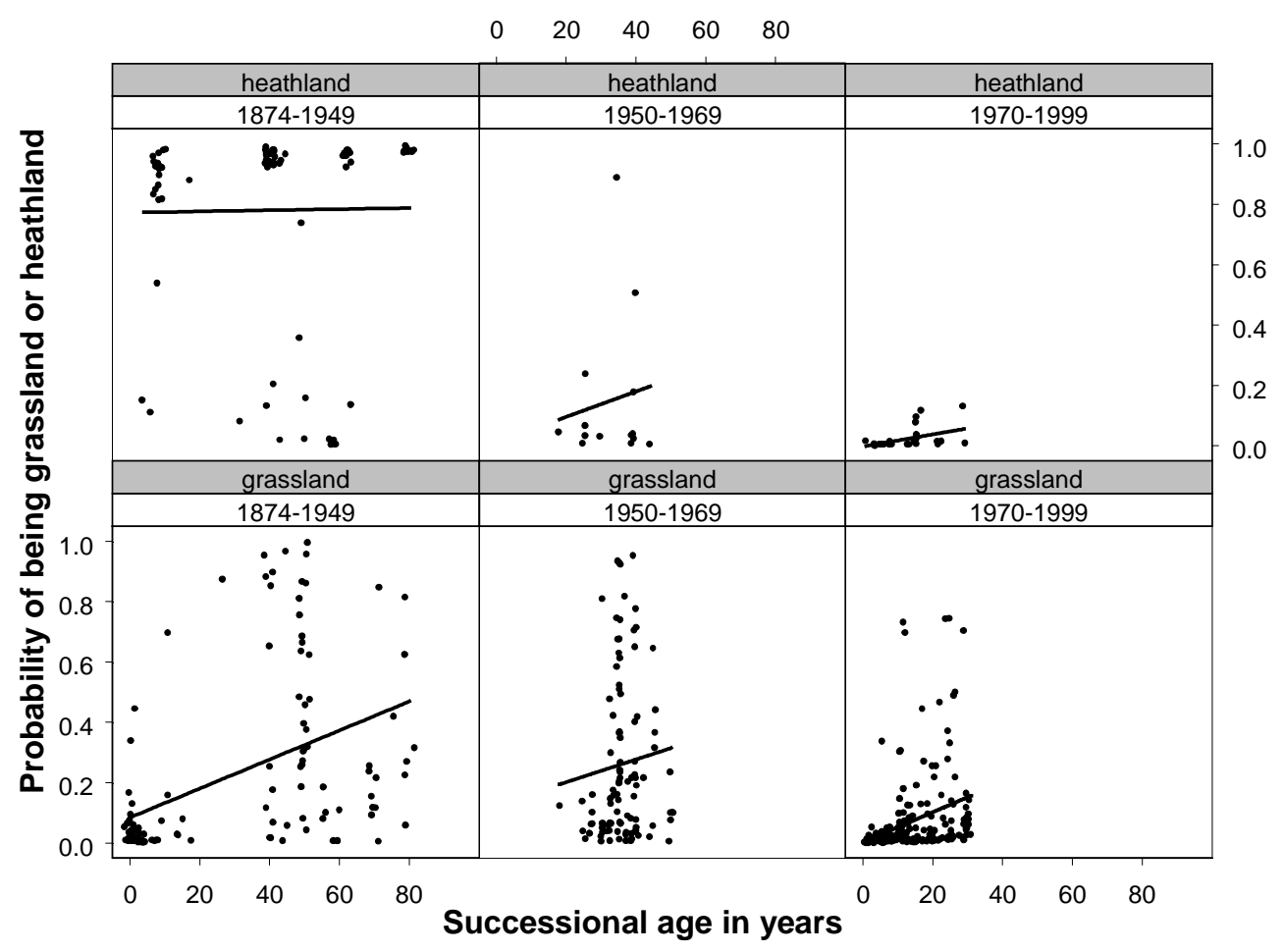

Figure 6. A panel plot of the classification model for probability of late successional phase. Sample plots and contour lines for model probabilities are plotted along DCA-1 and DCA-2 in subplots representing segments along DCA-3. All axes are normalised to the interval 0-1. Abandoned fields are represented by squares, grasslands by circles and heathlands by triangles.

Table 6 compares the predictions of the HQ-model (Ejrnæs et al., 2002a) with the prediction of the S-Model. The majority, 420 of 535 abandoned fields was predicted to be of high quality by the HQ-model. The remaining 115 plots are predicted to have low quality. The two models agree when it comes to the low quality plots -113 out of 115 is also predicted to be in early successional phase. But, as expected, a large fraction of the high-quality plots (308 out of 420) are predicted to be in an early successional phase. The disagreement between the two models is highly significant.

Table 6. Cross-table comparing predictions from the HQ-model with predictions from the Succession Model. Chi-squared test value $=31.99$ corresponding to a significance level $p<0.0001$, indicate a significant difference in predictions of the two models.

\begin{tabular}{l|ccc} 
& Late successional & Early successional & Totals \\
\hline High quality & 112 & 308 & 420 \\
Low quality & 2 & 113 & 115 \\
Totals & 114 & 421 & 535
\end{tabular}




\section{Application of the models to Norwegian data}

In 2001 the project funded the collection of Norwegian data from grassland vegetation along gradients in nature quality. The objective of this activity was to assess whether the developed methods were useful across wider geographical regions than just Denmark. The Norwegian data set consisted of 123 sample plots from 55 locations, including 318 species (taxa) of which many were rare (91 singletons, 44 doubletons).

We used the Norwegian data set as a case for testing the usefulness of the two models across wider geographical areas. The Norwegian samples were subjected to passive ordination and subsequent model prediction.

The Norwegian samples were classified into 5 classes:

- fallow fields and road verges (11 plots)

- improved grassland (mainly by fertilisation, 42 plots), and

- traditional grassland, which was further divided into three subclasses:

- abandoned grassland with encroachment (16 plots)

- recently abandoned grassland (16 plots)

- grassland with hay-cutting or grazing (38 plots)

Naturally, far from all Norwegian species were present in the Danish data sets. For the HQ-model 177 species were active, corresponding to $56 \%$ of the occurring species. For the $S$-model, 193 species were active, corresponding to $61 \%$ of the occurring species. However, most of the missing species were relatively rare, even in the Norwegian data set. The approach to and the results of the prediction of the Norwegian data can be seen in figure 7. The data was first run through the HQ-model, and samples found to have good habitat quality were also processed in the S-model. The final results can be seen in table 7 representing a cross-tabulation of Norwegian classes, and predicted quality of the two models.

Table 7. A cross-tabulation of Norwegian samples. The columns correspond to the Norwegian classification (see above) of the 123 samples, and the rows correspond to predictions derived from the Danish models (see figure 1 below). As seen in the table 80 $\%$ of the samples judged "good" were also classified as such, whereas $20 \%$ was judged bad. Oppositely $32 \%$ of the samples judged "bad" in the Norwegian classification were actually classified as good according to the Danish models.

\begin{tabular}{|c|c|c|c|c|c|c|c|}
\hline & distur & bed & & traditional & & & \\
\hline & fallow & improved & & encroachment & neo & & \\
\hline bad & 3 & 2 & & 3 & 1 & 6 & \\
\hline bad.hab & 2 & 29 & & 1 & 2 & 1 & \\
\hline & & & $67.9 \%$ & & & & $20.0 \%$ \\
\hline good & 2 & 1 & & 10 & 11 & 25 & \\
\hline good.hab & 4 & 10 & & 2 & 2 & 6 & \\
\hline & & & $32.1 \%$ & & & & $80.0 \%$ \\
\hline
\end{tabular}




\section{Norwegian data}

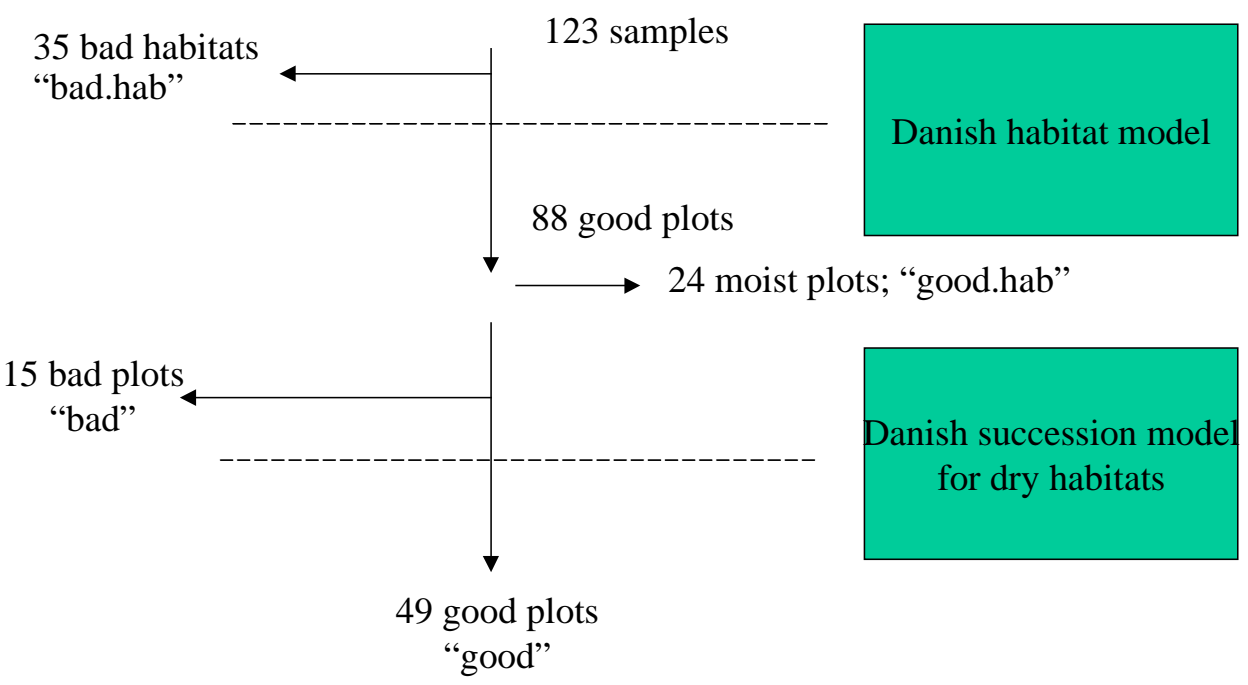

Figure 7. The first step sieved out 35 samples with bad habitat quality. Prior to the second model, 24 samples were recognised to be too moist/wet to qualify for the second model (assuming dry infertile soils) and these were classified as wet habitats with good habitat quality. Based on the second model, the remaining samples were classified as either semi-natural (49 plots) or successional (15 plots).

The model evaluation on Norwegian data revealed one clear complication. The encroachment, taking place as a result of ceased management, was clearly not caught by the models. This is not surprising, as the reference data was selected to reflect gradients in cultural improvement (HQ-model) and succession following ceased cultivation (Smodel). This result however should be used to stress that quality assessment models can only reflect gradients present in the reference data. In fact, this is true not only for models but also for indicator species lists.

The overall conclusion was that the Danish models worked surprisingly well on Norwegian data given the considerable geographical distance. We believe the reason for the encouraging result to be that the same basic processes of agricultural improvements take place in Norway and Denmark within the habitat type studied. It is basically the same species that increase in distribution and abundance after improvements. Obviously, a considerable number of the decreasing species are specific to either Norway or Denmark, but this is not a serious problem as long as there are some shared species in every sample plot. The misclassification error of the prediction on Norwegian data was nevertheless considerably larger than on Danish data, and we would therefore in general recommend that such models should be developed using data from the same geographical region.

\section{Discussion and perspectives}

We have described methods based on supervised classification using ordination gradients of a reference data set. Some of the advantages are obvious whereas others are 
subtle. Otherwise subjective evaluation of biological condition from species lists can now be carried out easily using standardised methods with documented statistical and biological properties. This also means that the principles and criteria for legislative protection and biological evaluations can be presented to the public in the form of standardised methods rather than subjective judgements. Standardised and reproducible methods are especially attractive with respect to the legal rights of landowners restrictions in land-use should clearly not follow arbitrary subjective judgements. The classifiers can be implemented on the World Wide Web (see below) with free access to end-users such as local and national managers, consultancy companies, landowners and schools.

Unlike subjective evaluations of conservation status, the classifier and its visual component, the ordination graph, may be used also to interpret small directional changes over time. This is demonstrated in figure 8, where a time series covering 26 years of secondary succession in an abandoned field on dry infertile soil (Degn, 2001) is projected on the ordination of the succession graph. The graph visualises a secondary succession that reaches the boundary between typical abandoned fields and typical grassland/heathland vegetation after approximately 25 years.

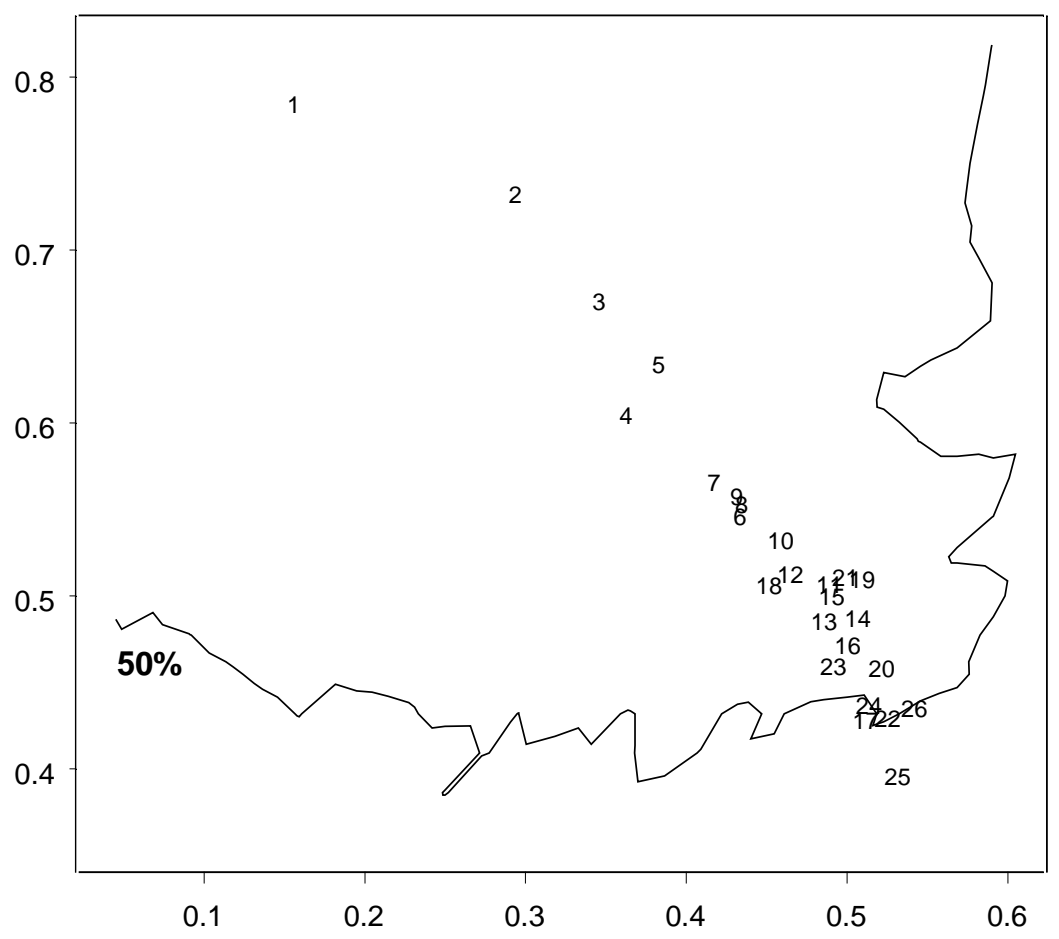

Figure 8. Projection on the succession model ordination of a 26-year time series of secondary succession on an infertile abandoned field (by passive ordination). The $50 \%$ probability line of the classifier is indicated. The graph only shows a section of the graph in figure 4 (data from Degn 2001).

We have given examples of two practical applications of the reference-based modelling approach, but more can easily be imagined. Take for instance the definition and delimitation of Annex I types of the Habitats Directive. These are defined in the Interpretation Manual (Anon. 1999), but the definitions may be hard to use in practice, 
especially in countries marginal to the geographic region covered by the directive. A classifier based on relevant reference data from the region in question may here be used to specify what the typical habitat looks like, how it may vary naturally and how it is distinguished from other habitat types (protected and non-protected). An example of this is given in the following chapter.

\section{Limitations}

Our approach has problems and limitations too. It may sometimes be hard to collect relevant reference data. Although most European countries have large databases with species lists suitable for ordination, biologists have had a tendency to collect data in localities of high conservation value and culturally disturbed habitats have often not been sampled. Some habitat types have received little attention, and for these types data may also be very sparse. In some occasions there are plenty of data, but it is questionable whether the sampled species group can be considered an appropriate indicator of conservation value. There is for example plenty of data on vascular plant species in Danish forest plots, but here, lichens, bryophytes, beetles and wood decaying fungi are possibly more relevant indicators of conservation value - or at least they indicate habitat features uncovered by vascular plants.

Even in situations with large suitable reference data sets, it is worth noticing the limitations of evaluation based on a classifier that uses ordination gradients for prediction. It should be remembered that ordination is based on the species present in the list, whereas absent species are generally disregarded. As mentioned above, ordination does not reflect species richness but species composition. This means, that if an environmental change leads to local extinction of a number of species without any compensatory immigration of new species that are better adapted to the new environmental conditions, then ordination may not detect this change. The most obvious situation of this kind is the early succession following cessation of traditional grazing or cutting in grasslands. The first thing to happen will typically be an expansion of coarse grasses and herbs at the expense of small-stature species.

This kind of succession is obviously not within the universe of discourse of the two models developed in our project, and this is also clearly revealed in the evaluation of the two models on Norwegian data. On the other hand, as long as the succession involves major changes in the relative abundance of species, and given the existence of appropriate data, models for assessing the effects of dereliction could easily be produced. One may imagine however cases where the first subtle response to environmental changes involves a disappearance of a number of particularly vulnerable species, without immigration of "alien species", and no major changes in the frequency and abundance of surviving species. In this case, ordination-based models would be of little use.

It may be argued generally, that the first change following a human alteration of environmental condition is to be detected in chemical and physical rather than biological parameters. On the other hand, such detection requires that relevant parameters have been collected. And as experienced in aquatic monitoring it may be hard to forecast which physical and chemical parameters are the relevant predictors of biotic condition (Barbour et al. 2000). In conclusion, evaluations based on species composition should therefore be combined with evaluation of monitoring data on both 
the population trends of vulnerable species and on the physical and chemical condition of habitats.

\section{Rarity, diversity and conservation value}

As discussed above, diversity and rarity are often used for valuation. Diversity is used as a general objective for conservation - a change that leads to loss of diversity is intuitively judged as negative. The occurrence of rare species is typically used as an argument for paying special attention to a locality.

Clearly, rarity and diversity are not directly involved in the value assessment emerging from the models. In fact, we find this attractive, as neither diversity nor rarity can be claimed to be inherent or characteristic properties of natural ecosystems. This, somewhat controversial, statement may need some further explanation. As discussed under the HQ-model above, several natural ecosystems have naturally low richness in one or more species groups - this is the case e.g. in oligotrohic mires and bogs as well as dunes and heathland. In these ecosystems most human disturbances will lead to increased species richness. Sometimes the immigrating species will be easy to disregard - e.g. opportunistic ruderal or nitrophile species totally alien to the community. On other occasions, a number of rare native species may expand their distribution and boost species richness - e.g. when a field is limed, cultivated, depleted and then left for natural succession in an otherwise acidic heathland. From a naturalness point of view, the value is not related to the diversity per se, but to the set of species adapted to that particular natural environment.

Rarity is slightly different. Again we would argue that rarity is not a desirable or typical property of natural ecosystems. Some species are naturally rare, but today rarity may have many causes. Some species are naturally rare because they live as subordinate species in a naturally rare habitat type or occur close to their climatic or distributional limit. Other species have become rare because they live in a habitat type that has become rare due to human habitat destruction. A third group may be rare because they have recently immigrated - and these are typically anthropochorous species. The second group of rare species may indicate valuable and threatened ecosystems, but only if they have been found. And, quite obviously, rare species will only be found in a small subset of the suitable localities.

In out study, we tested and confirmed that the HQ-model was able to recognise the high quality of habitats for rare vascular plants. And, because this assessment only needed the input of a species list from a plot, it is much more cost-effective and reliable, than assessments that require extensive searches for rare species. On the other hand, it should be stressed that knowledge about the occurrence of rare species is a fact to be considered in the prioritisation of resources spent on conservation. Rare species are in danger of local or regional extinction, and this should be considered serious if they have been driven to this point by human habitat destruction. We would like to stress however that rare species as a prioritisation parameter should be balanced against other valuable properties of localities, such as uniqueness (habitat rarity), size and conservation status.

\section{Baselines and targets}

As a final remark, we would like to return to the importance of scientific agreement about the concept of reference condition or baseline. Such consensus is a prerequisite 
for the establishment of reference data sets and relevant assessment models. We suggest that it may be sensible to think of two levels of reference condition. The first level is essentially the condition that would prevail without human interference - i.e. the natural baseline of species, habitats and ecosystems. This baseline is essential to our scientific understanding of the ecological and evolutionary preconditions for biological diversity. We suggest calling this the natural baseline. The natural baseline should be defined with reference to the state of the art knowledge of palaeoecology and evolutionary ecology. And, acknowledging the limited biotic evidence available from disciplines such as palynology, we will need to complement this knowledge with insights from community ecology and autecology. It is inevitable that most natural baselines will include elements of uncertainty.

The second level is a baseline that defines the degree of naturalness that is achievable an affordable given the ecological reality of today's landscapes. We may call this the pragmatic baseline. The pragmatic baselines should refer to the natural baseline. In order to be useful in practice, the pragmatic baseline has to take into account the changes that humans have enforced on landscapes, habitats and species pools, some of which are irreversible, e.g. global extinction of keystone species. The pragmatic baselines should be operational. If we take a habitat type as example, the pragmatic baseline should specify the reference species composition, species richness, ecosystem properties (nutrient pools and cycling, natural disturbance regime etc.) as well as its area and geographical distribution. Actually this is precisely what is asked for in the Habitats Directive. The pragmatic baseline will thus constitute the reference against which to measure the biological condition and the performance of mitigation management.

Targets (or objectives) differ from baselines, as they are politically determined. Targets take into account the willingness of society to offer resources on the protection of biological diversity and natural processes. Objectives are typically outlined in legislation for nature protection, such as the Habitats Directive or the Danish Nature Protection Act. The legislation is typically imprecise and non-operational, and that is where baselines and targets meet. Baselines define the endpoints on the continuum from destroyed ecosystems to high quality ecosystems. Reference-based models of the kind presented in this report expand the assessment to include the entire continuum along which decision-makers may define targets in accordance with their ambitions. 


\section{Models in an information framework}

Previously we have described how models can be used to analyse species data, and now we will proceed to discuss the role that models could play in the communication of results to the society. In other words, what is the role of models in the web of knowledge, motivation, advice and decision that connects scientists, managers, decision-makers and the general public?

A logical first step in the development of an information framework for biological conservation would be an identification of societal needs for information. The society cannot be conceived as one agent with one set of demands. When it comes to biological diversity, the general public, including the politicians, demand information on a certain generalised level, whereas specific institutions such as the ministry of environment, the EU-commision and OECD demand more specific and detailed information. The managers and the scientific institutions require even more detailed information to be able to give appropriate advice and plan the necessary management.

In this chapter we envision such an information framework. We imagine that the information to be digested and distributed derive from local activities that may be divided in mapping, monitoring and management. Data from these activities are further processed and aggregated by statistical methods in order to assess biological condition and trend and to provide relevant outputs on scales ranging from a specific locality to the national scale. We will consider, as a case study, the information framework of the implementation of the Habitats Directive in Denmark, and describe the role for nature quality models as well as supplementary sources of information within this framework.

\section{Mapping of terrestrial habitat types in Denmark}

53 terrestrial habitat types from Annex I on the Habitats Directive have been recognised in Denmark, and 254 habitat areas have been designated for the protection of habitats and species mentioned in annex II and IV (see fig. 7). 


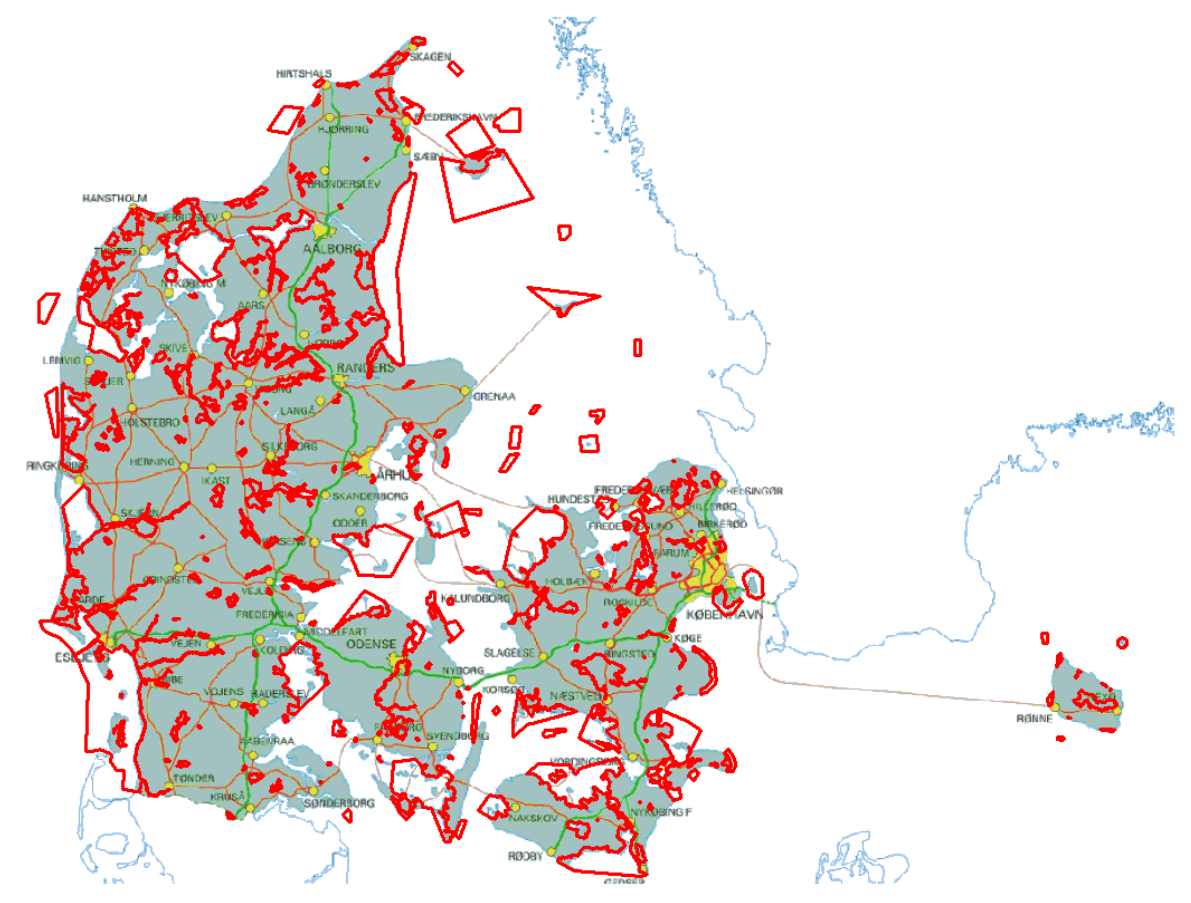

Figure 9. 254 designated habitat areas in Denmark.

Within these areas a detailed mapping of the distribution and identity of habitat types has been undertaken by the Danish counties. The mapping activities have, although not completed yet, revealed a number of difficulties. One difficulty lies in the correct identification of types including the discrimination between different types and the separation of protected and unprotected areas. The mapping has gradually improved as a number of more clear type definitions and descriptions have emerged during the course of the mapping. Nevertheless procedures for assessing the accurateness of mapping have not been applied yet. A second difficulty, related more to the inherent properties of ecosystems than to the imperfection of the mapping competence, is the recurrent occurrence of more than one habitat type within relatively small areas, i.e. mosaic ecosystems. Such mosaic types often occur within dunes, heathlands and wetlands.

\section{Reconciling classifications}

Supervised classification of the kind we have seen in above can be used not only for assessing conservation value, but also for reconciliation of different classification systems. A study (Ejrnæs et al. In press), developing from this project, on dry grassland habitats in Denmark has shown how the grassland type definitions of the Habitats Directive can be used to classify Danish grasslands (Bruun \& Ejrnæs 2000) according to the Habitats Directive. Figure 10 shows how plots from the four main types of grassland in Denmark disperse along the two major gradients in these grasslands (see Ejrnæs \& Bruun 2000 for a gradient analysis). The four main grassland types in Denmark are: xeric grassland, acidic grassland, calcareous grassland and sand grassland. Figure 11 demonstrates how the ordination space may be divided into the three Habitat Directive grassland types. As revealed from the analysis (Ejrnæs et al. in press), sand grassland is not covered by the three Annex I grassland types, while there is, as expected, a reasonable fit between Annex I type 6210 and calcareous grassland, Annex I type 6120 and xeric grassland and Annex I type 6230 and acidic grassland. The documentary plots 
from the mapping of grassland types within designated habitat areas are also projected onto the diagram. In this way it is possible to test and confirm that the mapping of grassland types correspond reasonably with the type definitions of the directive.

\section{Intended recipients}

A classification model for numeric supervised classification may be used directly by field biologists as an aid in the identification of types and discrimination between protected and non-protected habitats. This may be of interest not only to field biologists carrying out the mapping inventories, but also to consultancy companies dealing with environmental impact assessment. In such cases, tools for prioritisation between habitats could possibly increase the cost-effectiveness and reliability of overall assessments. The second types of recipients are the Danish Ministry and EU that in the end receive the monitoring results showing the development in the state of habitat types including the current trend in area and distribution of types. Although these users would never come in touch with the method, supervised classification could help ensuring the consistency and quality of the mapping results.

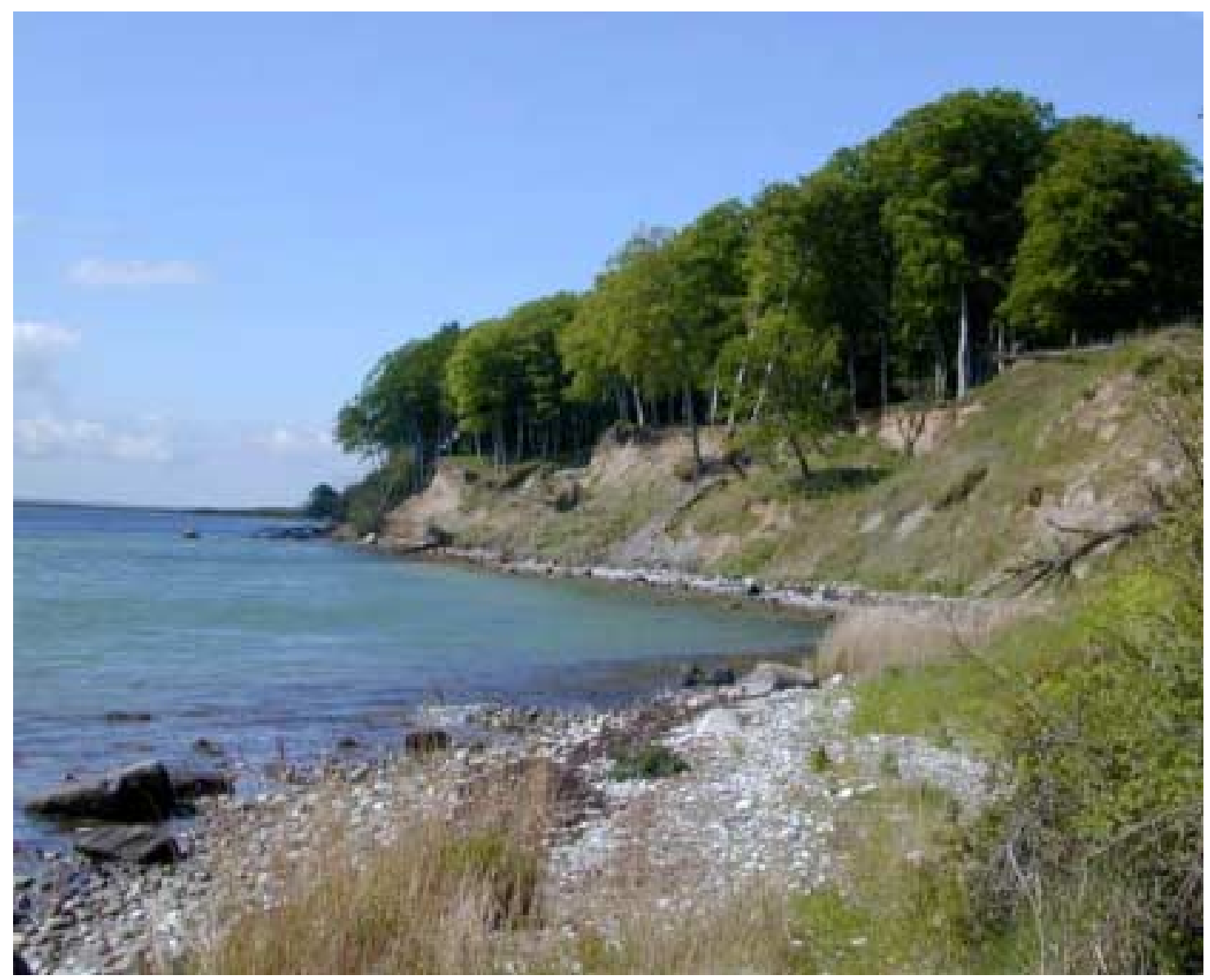

Natural coast, vegetation grazed by fallow deer, Abbelф, Denmark. Photo: Carsten Riis Olesen 


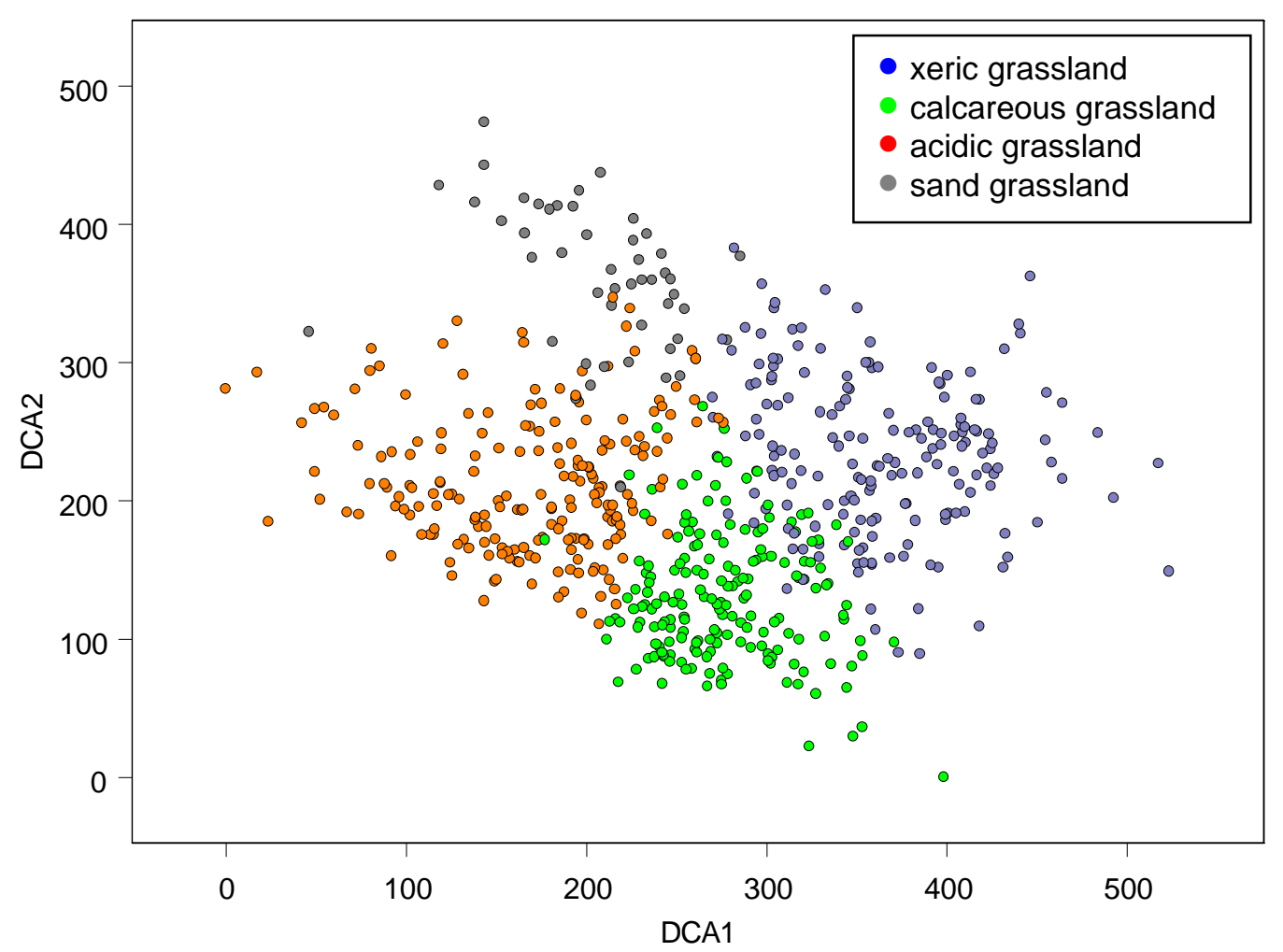

Figure 10. The projection of 620 grassland plots classified to one of four main grassland types in Denmark on to the two primary axes of a DCA-ordination.

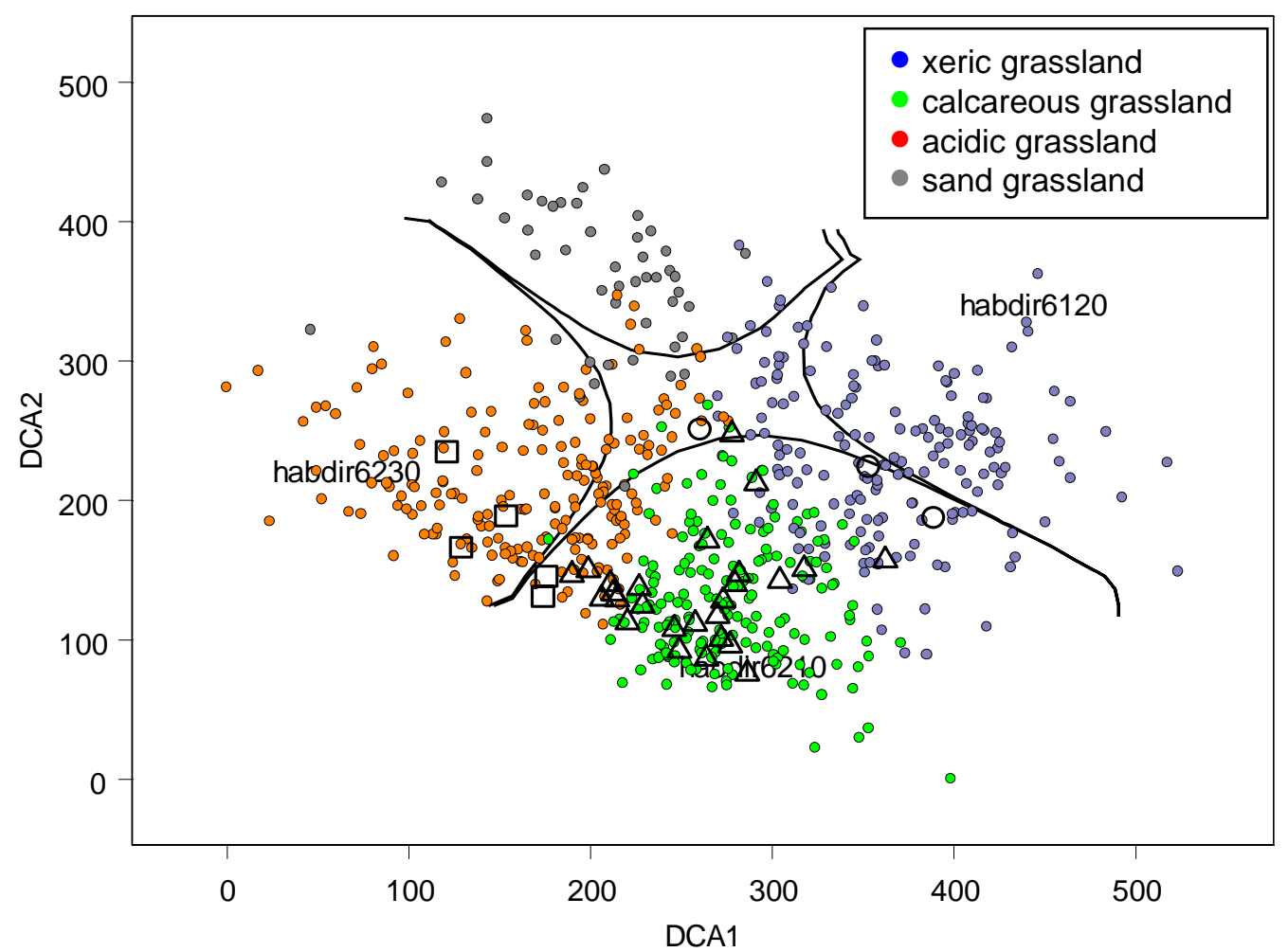

Figure 11. A copy of figure 10, but here contour lines for classification of data into grassland type are indicated. The position of documentary samples from the countywise field mapping of Annex I habitat types is shown: squares are type 6230, triangles type 6210 and circles are type 6120. 


\section{Monitoring}

The Habitat directive requires a report every 6 year that indicates whether the habitat types and species within the biogeographical zones of the country are in favourable conservation status. When it comes to the habitats, favourable conservation status is defined according to area, distribution, structure, function and typical species (Anon 1992a).

We can thus conclude that appropriate information required for the reporting of conservation status should be derived from monitoring of habitat area and distribution, structure and functions of the habitat and populations trends of its typical species. In this project we have developed tools that may be used for monitoring structure and functions (by indication of environmental conditions). The models are, as we will see below, also potentially useful for monitoring area and distribution.

\section{Mosaic ecosystems}

The occurrence of habitat types in small-scale mosaic represents a specific problem for monitoring. The Habitat Directive demands a repeated assessment of trends in the area and distribution of habitat types on a national scale. It is however not possible in practice to reproduce a detailed map of habitat types if a large number of occurrences are characterised by a mosaic of several types. One solution to this problem is a point based monitoring where the initial mapping of types is used for stratification of sample points. By use of supervised classification each sampling point may, on each monitored occasion, be assigned to the most appropriate type, and consequently changes in the area and distribution of types may be monitored in a reproducible way. Obviously, the number of sample points that can be afforded in a single locality will be too small to detect subtle changes in the area of habitat types within that locality, but the total number of samples in a habitat type in Denmark will be very large, and could thus be expected to give a robust trend estimate.

\section{Extensive surveys}

As mentioned in the previous chapter, it is paramount that the sampling of species data and subsequent modelling is combined with environmental monitoring and population monitoring of vulnerable species. On the other hand, the collection of a species list may in some occasions be the only affordable type of survey. In Denmark this is the case in valuable habitats outside the habitat areas where no monitoring resources have been allocated. There are still habitat types to be found here that are covered by the national nature protection legislation, but they will only be covered by low-cost surveillance. In this case, nature quality models can be used to extract as much information as possible from collected species lists.

\section{Intended recipients}

The output from applying the models to time series data from monitoring is of interest to scientists, managers and authorities. From the scientific point of view much is known about the ecological preconditions for different ecosystems, but less is known about the natural and non-natural dynamics. From the managers point of view it is obviously interesting to see the changes occurring in a single locality against the background of a large reference data set. The model outputs offer an assessment of the relative 
magnitude of changes and may also give useful hints about the causes for the observed changes. The national and international bodies will be offered crucial information regarding trends in area and distribution as well as environmentally interpreted trends in biological condition.

\section{Aggregation}

Aggregation of data from the local level to the national level is needed for meeting the demands of the Habitats Directive, but also for providing information about the state of the environment to the general public and to politicians.

Assessment models of the kind in our project may be used to carry out nation-wide partitioning of trends. Significant trends may be categorised according to pressures such as eutrophication, ceased management, hydrological changes etc. A number of sample points may also have changed habitat type due to e.g. succession or environmental changes, and with quantitative data this could easily be visualised.

Also, habitats of unfavourable conservation status may be divided on groups according to the primary reasons for the unfavourable condition.

The communication of terms such as "favourable conservation status" and "habitat type" to the general public and to politicians is nevertheless troublesome. Behind these terms, fundamental assumptions and definitions are hiding, and there is a danger that people without specialist knowledge will find them meaningless. As a consequence there is a need for simple, yet scientifically sound, concepts that can be used to communicate trends in the conservation status of our natural environment. Here, we would like to introduce the very simple concept "Natural Capital Index", developed in the Netherlands (Ten Brink \& Tekelenburg 2002, van Hinsberg et al. 2003). We will discuss how this concept fits into an information framework for the Habitats Directive.

\section{From data to indicators}

The Natural Capital Index (NCI) is a visualisation of two basic features of our ecosystems, namely quantity and quality. Quantity is understood as the area occupied by different valued ecosystems, whereas quality is understood as the conservation status of these ecosystems, measured as the diversity of characteristic species. There is thus a direct link between NCI and biodiversity.

$\mathrm{NCI}$ is visualised as a box with an $\mathrm{x}$-axis corresponding to quantity and a y-axis corresponding to quality, and each axis ranges from 0 to $100 \%$ (figure 12). The axes are relative axes, and axes endpoints, i.e. $100 \%$, are defined with reference to the baseline of the ecosystem in question. This means that following the NCI, our natural capital can never be larger than baseline condition. Baseline is defined as ecosystem area and ecosystem quality at a point in the past where human impact was negligible or at least very modest. 


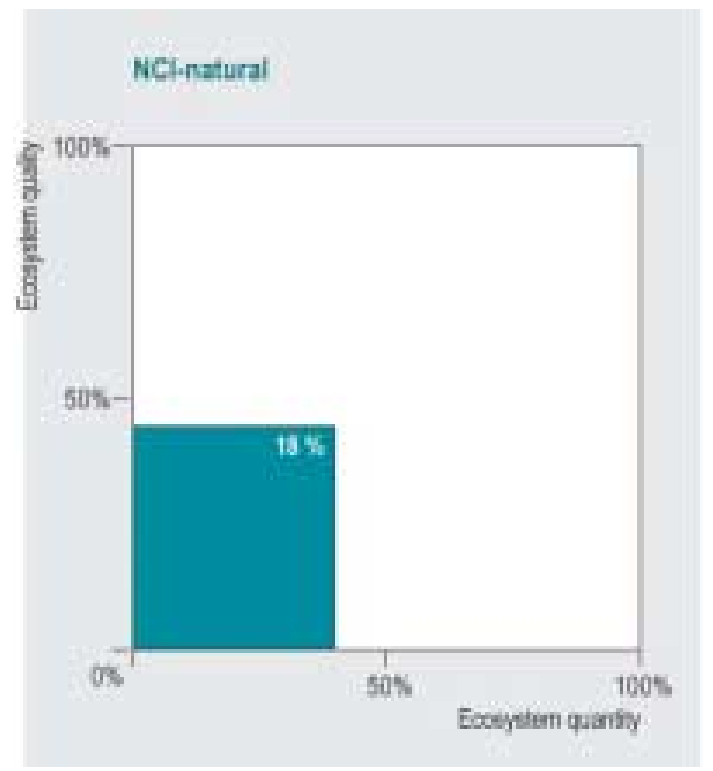

Figure 12. The Natural Capital Index. NCI is $18 \%$ for natural areas in the Netherlands.

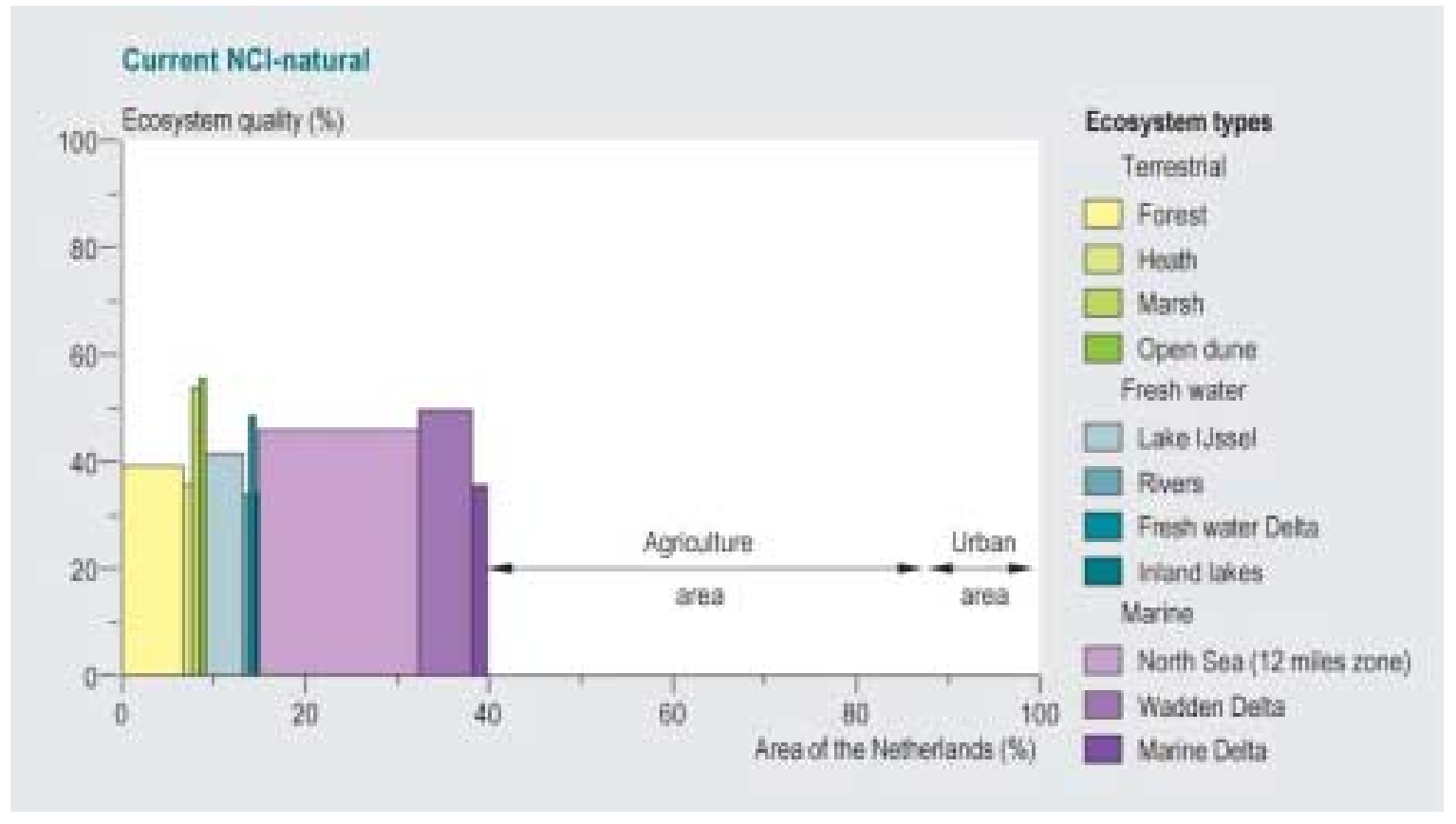

Figure 13. NCI divided on different types of natural areas, including marine ecosystems.

NCI can be visualised at the very general aggregated level of natural areas as a whole (figure 12), but it can also be dissolved in its component ecosystems as in figure 13. From this figure it is obvious that the marine natural areas constitute most of the total natural area in the Netherlands. The figure also reveals that although some differences 
in quality between the component ecosystems can be observed, most Dutch ecosystems are highly impacted compared to their baseline quality. But how is this quality derived?

\section{Aggregation protocol for quality}

The calculation of ecosystem quality follows a protocol for comparison of present diversity of native species with the baseline diversity of these species. In the Netherlands, the NCI is based on the monitoring of more than 1000 species of breeding birds, mammals, fish, reptiles, butterflies, vascular plants and soil macrofauna. These species has been selected to represent native species characteristic for the 32 ecosystem types, and the selection includes species along the continuum from common to rare species. The monitoring is carried out in 32 ecosystem types, being the combination of habitat types and geographical units (e.g. soil-climate combinations).

For each species, a natural baseline frequency within each ecocystem type has been defined. For example, literature studies and expert knowledge has shown that the natural frequency of species $x$ in ecosystem type $y$ is $60 \%$. The result of the inventories is then used to calculate the $\%$ fulfilment of the baseline frequency for all species.

In the calculation of ecosystem quality, three groups of species are given equal weight: Vascular plants, invertebrates, and vertebrates. This means that the mean percentage deviation from baseline frequency of each group counts one third to the aggregated figure of ecosystem quality. Because the NCI is based on the aggregation of species within ecosystem data, there are plenty of opportunities for more detailed analysis and reporting of trends. As previously mentioned, changes in the NCI can be reported for specific ecosystems, but trends can obviously also be reported for groups of species selected to represent particular habitat types or particular ecological adaptations (e.g. figure 14).

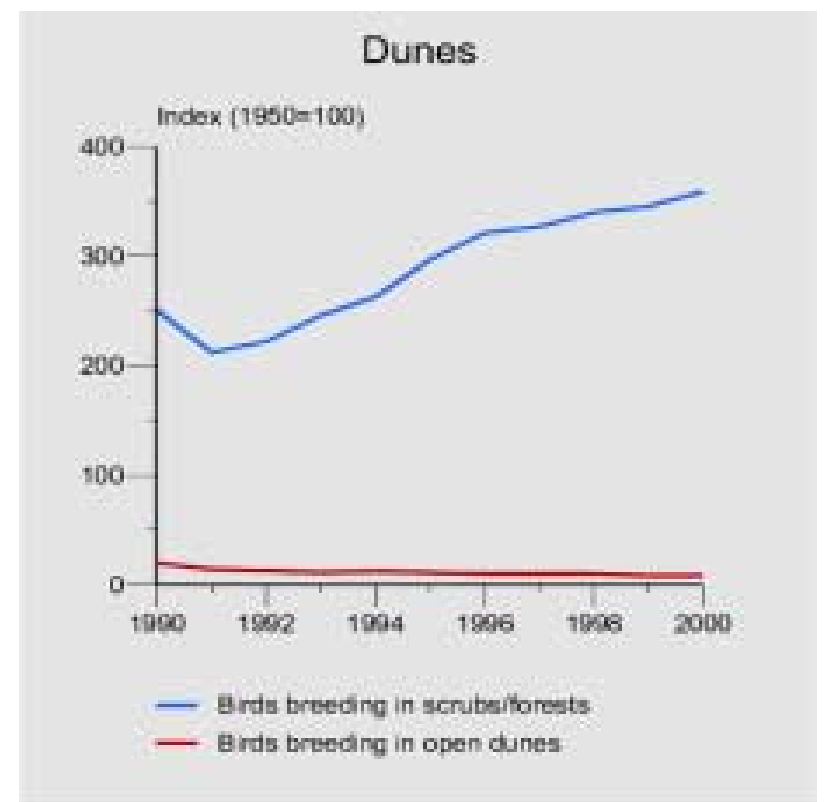

Figure 14. Changes in the frequency of two groups of breeding birds in Dutch dunes from 1990 to 2000. Baseline value, defined as the frequency in 1950, is set to index 100. 


\section{$\mathrm{NCl}$ within the information framework}

Although the NCI is not a figure demanded for the reporting of conservation status for the Habitats Directive, it is an intuitively appealing and scientifically sound way of communicating trends to people without biological insight in the conservation of habitat types. Moreover, as shown by the Dutch developers (ten Brink 2000), the approach is very general, and ecosystem quality may be calculated using different set of indicators, i.e. not necessarily a fixed set of more than 1000 species. In cases without species data, it would even be possible to use known environmental pressures as proxies for ecosystem quality. Consequently, much could be gained from using NCI in combination with the nature quality models developed in this project.

Whereas the models would typically use species data from one specific species group, the NCI could use both species data and other indicators of conservation quality collected in the monitoring programme. And whereas the models can be used to track changes in single habitats along environmental gradients, and communicate these to managers and conservation biologists, NCI can be used to communicate changes across habitat types, regions or species groups to the general public and decision-makers.

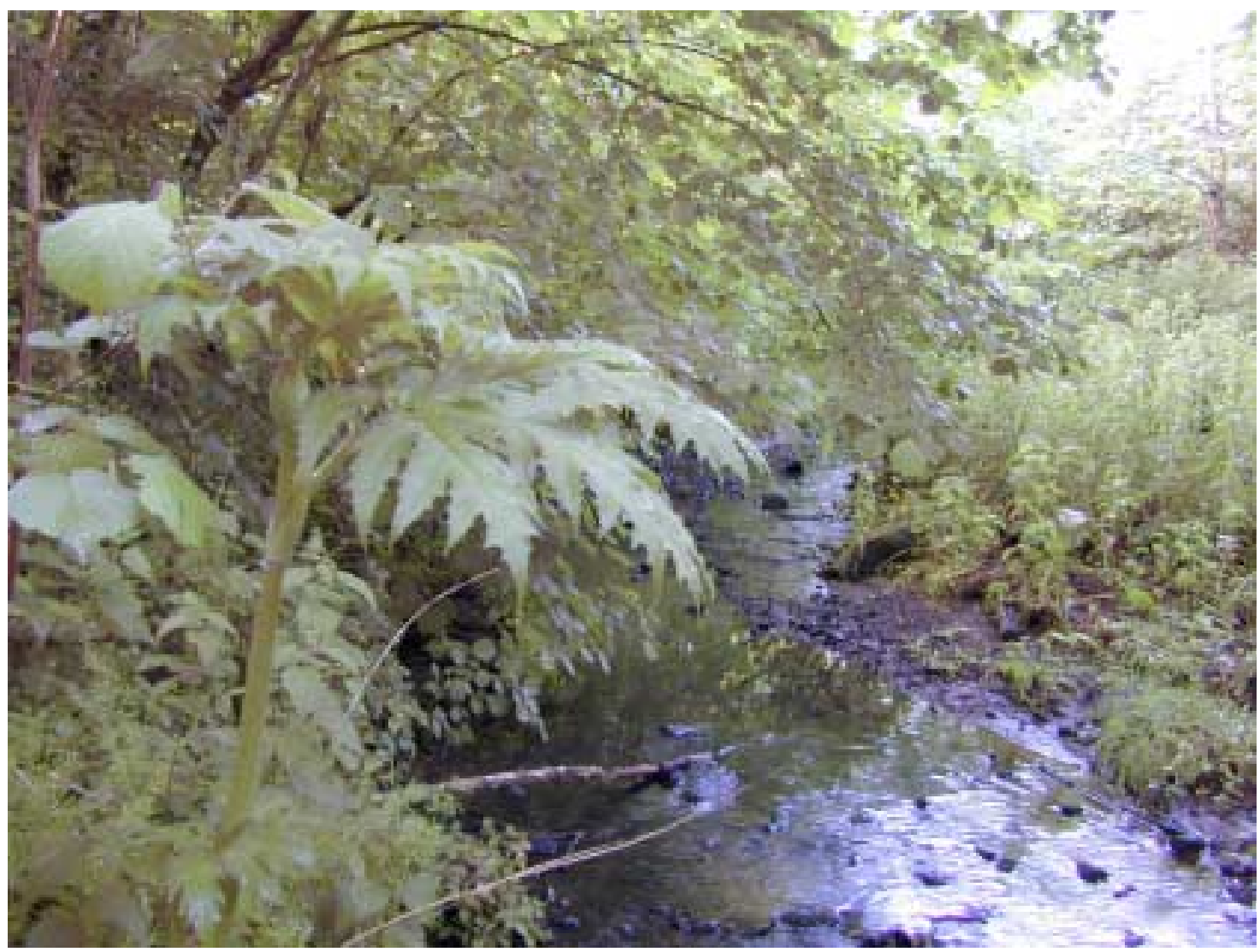

The invasive species Heracleum pubescens, here invading a natural stream. Photo: Rasmus Ejrnas 


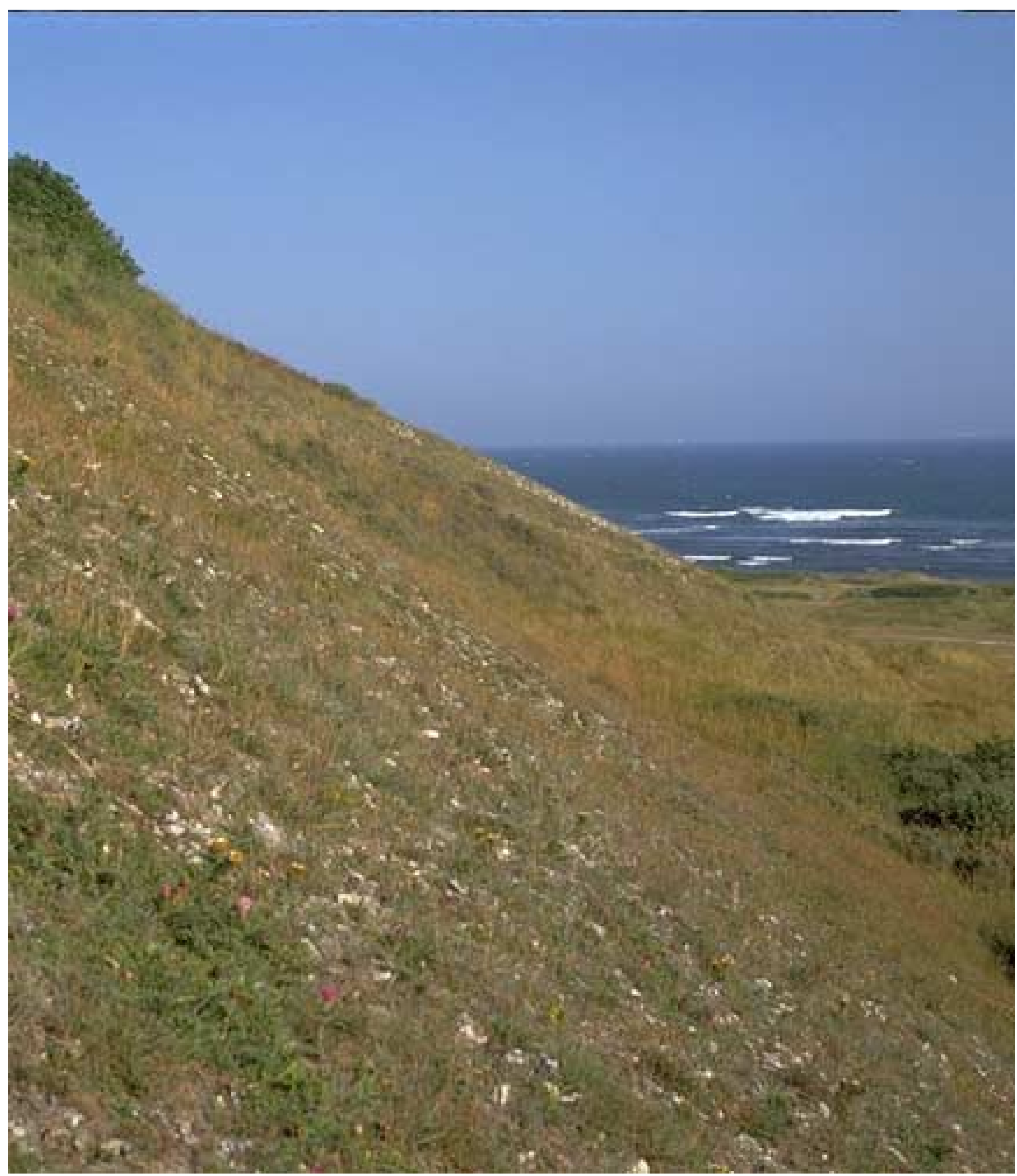

Calcareous grassland rich in rare species close to Hansthom, Denmark. Photo: Rasmus Ejrnaes 


\section{Public access through the Internet}

Models are interesting and stimulating from a theoretical point of view, as they may be used to demonstrate mechanisms and patterns that are so general that they can be reproduced. The usefulness of models depends however on their penetration of everyday life. Models, which are restricted to be run on the developer's personal computer, by the developer, have limited applied value. For this reason we invested time in making the developed classification models accessible to the public through an Internet interface. On the WWW address www.danveg.dk it is now possible to access and use the developed classification models interactively, and obtain classification of new species lists entered through an Internet interface. The methodology and interface is described below.

\section{Methods for interactive classification}

In the previous two chapters, we described three classification models, the Habitat Quality model (p. 41-47), the Succession Model (p. 47-52) and the Habitats Directive Grassland Type model (p. 60-62). These models all use ordination scores for classification. Ordination scores derive from a DCA-ordination (p. 38) of species lists from reference data sets. As DCA-ordination implies a simultaneous ordination of species and plots, ordination scores for new plots may be obtained by passive ordination. An ordination score for a new site may simply be calculated by looking up the species occurring in the new species list in a table of species scores from the reference ordination and taking the arithmetic mean of these species scores (fig. 15). This new site/plot ordination score then enters the classification model.

\section{Classification model}

For effective implementation on the Internet, we have chosen to substitute the more sophisticated classification methods (e.g. artificial neural networks, discriminant analysis, multinomial regression) with a simple and robust alternative, namely nearest neighbour classification (Ripley 1996). Nearest neighbour classification classifies new observation by a two-step procedure. First, the n-nearest neighbours among already classified observations are found. Second, these nearest neighbours are used to determine the most likely class of the new observation - either by a majority vote, or, as we have done, by taking the mean of the class probabilities of the nearest neighbours.

In our case, the 5-nearest neighbours are found by calculating the euclidean distance in ordination space between the new observation (new species list) and all classified observations in reference data.

A comparison between the different methods for classification shows a convincingly high agreement between nearest neighbour classification and the more sophisticated methods. On average less than $1 \%$ of data were classified differently by nearest neighbour classification (Table 8).

The effectiveness of the Internet implementation means that it takes only few seconds from the species list is submitted to the classification result is calculated. 
New species list Cynosurus cristatus Carex flacca Prunella vulgaris Festuca rubra Festuca pratensis Trifolium medium Polygala vulgaris Cirsium acaule

Carex hirta Antennaria dioica

\begin{tabular}{|c|c|c|c|c|}
\hline & Species name & DCA1 & DCA2 & DCA3 \\
\hline & Cynosurus cristatus & 140 & 125 & -17 \\
\hline & Carex flacca & 199 & -67 & -16 \\
\hline \multirow{10}{*}{$\begin{array}{l}\text { Lookup } \\
\text { species }\end{array}$} & Prunella vulgaris & 156 & 69 & -15 \\
\hline & Platanthera bifolia & 470 & 35 & -13 \\
\hline & Primula veris & 157 & -21 & -12 \\
\hline & Trifolium medium & 261 & 69 & -6 \\
\hline & Festuca rubra & 83 & -11 & -4 \\
\hline & Nardus stricta & 484 & 55 & -2 \\
\hline & Polygala vulgaris & 325 & -8 & -2 \\
\hline & Mentha arvensis & 31 & 374 & -1 \\
\hline & Hieracium aurantiacum & 235 & -42 & 0 \\
\hline & Galium aparine & 150 & 420 & 12 \\
\hline \multirow{3}{*}{$\begin{array}{l}\text { mean } \\
\text { scores }\end{array}$} & Poa annua & 52 & 352 & 12 \\
\hline & Cirsium acaule & 139 & -65 & 14 \\
\hline & Carex ovalis & 370 & 295 & 25 \\
\hline \multirow{2}{*}{$\longrightarrow$} & Stellaria holostea & 268 & 262 & 25 \\
\hline & Carex hirta & 237 & 99 & 28 \\
\hline DCA3 & Antennaria dioica & 441 & 3 & 29 \\
\hline $5 \quad-17$ & _. & $\ldots$. & $\ldots$ & $\ldots .$. \\
\hline
\end{tabular}

\begin{tabular}{lrrr} 
Species & DCA1 & DCA2 & DCA3 \\
\hline Cynosurus cristatus & 140 & 125 & -17 \\
Carex flacca & 199 & -67 & -16 \\
Prunella vulgaris & 156 & 69 & -15 \\
Festuca rubra & 83 & -11 & -4 \\
Festuca pratensis & NA & NA & NA \\
Trifolium medium & 261 & 69 & -6 \\
Polygala vulgaris & 325 & -8 & -2 \\
Cirsium acaule & 139 & -65 & 14 \\
Carex hirta & 237 & 99 & 28 \\
Antennaria dioica & 441 & 3 & 29 \\
Mean ordination score & 204.6 & 9.9 & 3.1
\end{tabular}

Passive ordination

Figure 15. Diagram showing the principles of passive ordination. The species occurring in a new species list is looked up in the table of species scores for the reference ordination and a mean is calculated from species occurring on both lists.

Table 8. The classification disagreement between 5-Nearest Neighbour classification and the more sophisticated models used to develop the classifier and classify the reference data sets.

\begin{tabular}{|l|l|l|}
\hline Comparison & Method & Misclassification rate \\
\hline Habitat Quality model & Neural network & 0.0008 \\
\hline Succesion model & Neural network & 0.006 \\
\hline Habitat type model & Discriminant analysis & 0.016 \\
\hline
\end{tabular}




\section{Database technicalities}

The database, DANVEG, is a web application built using the Active Server Pages technology (ASP). The database is MS Access 2000, and the routines are programmed in Visual Basic Script, Javascript and HTML. The routines are executed on a Windows 2000 server with Internet Information Services installed.

\section{User interface}

The user interface of DANVEG uses Danish as language, but hopefully resources will be allocated to translate it into English too, which will make it accessible for an international audience. Although the applications are using Danish data as reference for classification models and community descriptions, the approach may hopefully inspire other nationalities.

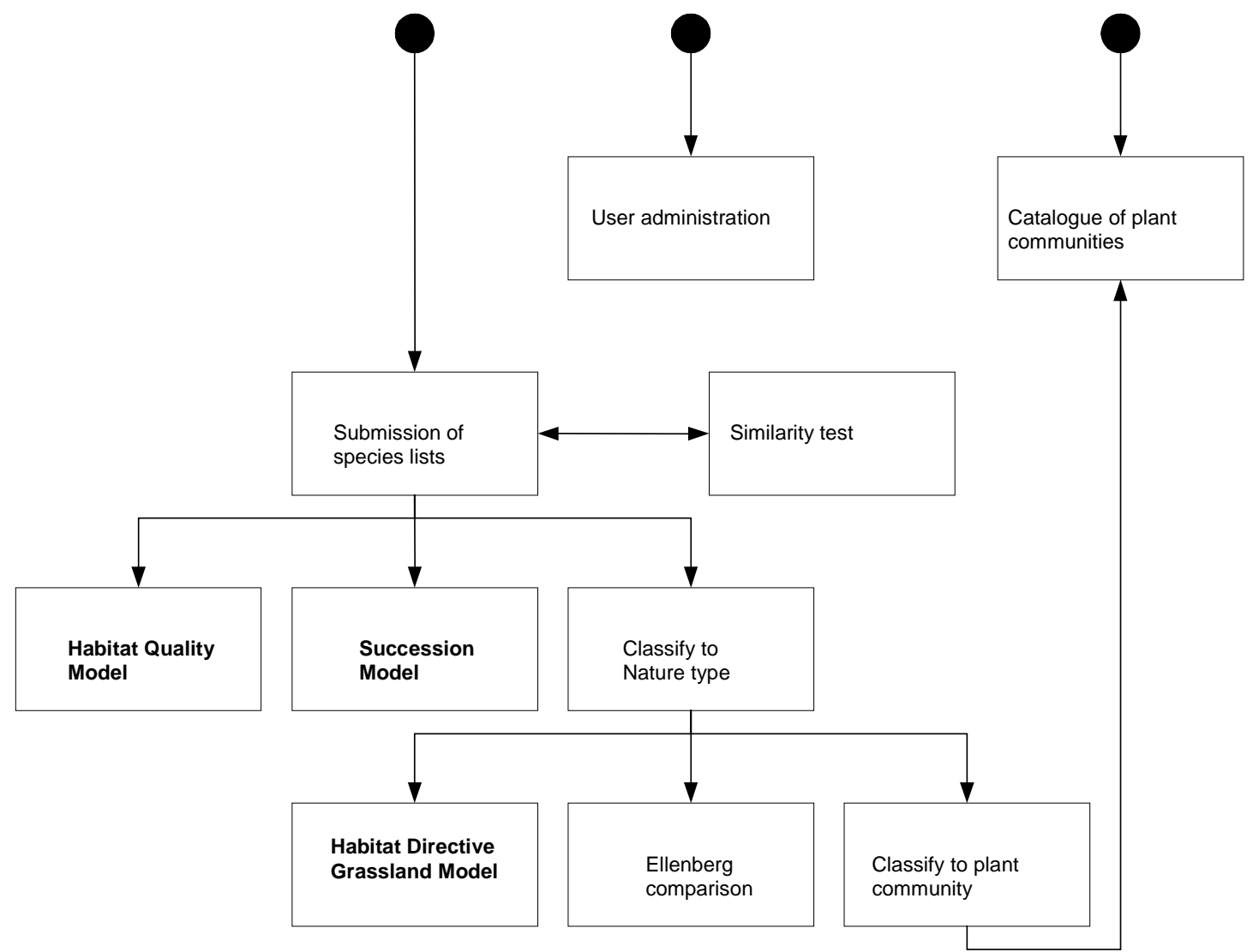

Figure 16. A diagram of the user interface of DANVEG. From right to left, the user may 1) browse passively through the plant community catalogue, 2) register as user and 3) interact with the reference data and models by submission of own data through the species list submission feature. The position of the three classification models of this study is indicated with bold letters. The user administration enables a user to save submitted data for investigation on a later occasion. The similarity test make an initial assessment of the appropriateness of submitted data for comparison with reference data. 
DANVEG has two main features (fig. 16). First, it contains a collection of Danish species lists obtained from a wide range of different terrestrial plant communities. These species lists have been subjected to hierarchical clustering and have subsequently been organised in distinct nature types (e.g. grasslands, wetland and dunes), and further divided into major plant community types (e.g. calcareous grassland, acidic grassland) and specific plant communities (e.g. Dactylis glomerata-ranunculus bulbosus grassland). The plant communities may be browsed and information may be obtained regarding the typical species of each plant community as well as the geographical location within Denmark of documented occurrences of a specific plant community (fig. $17,18)$.

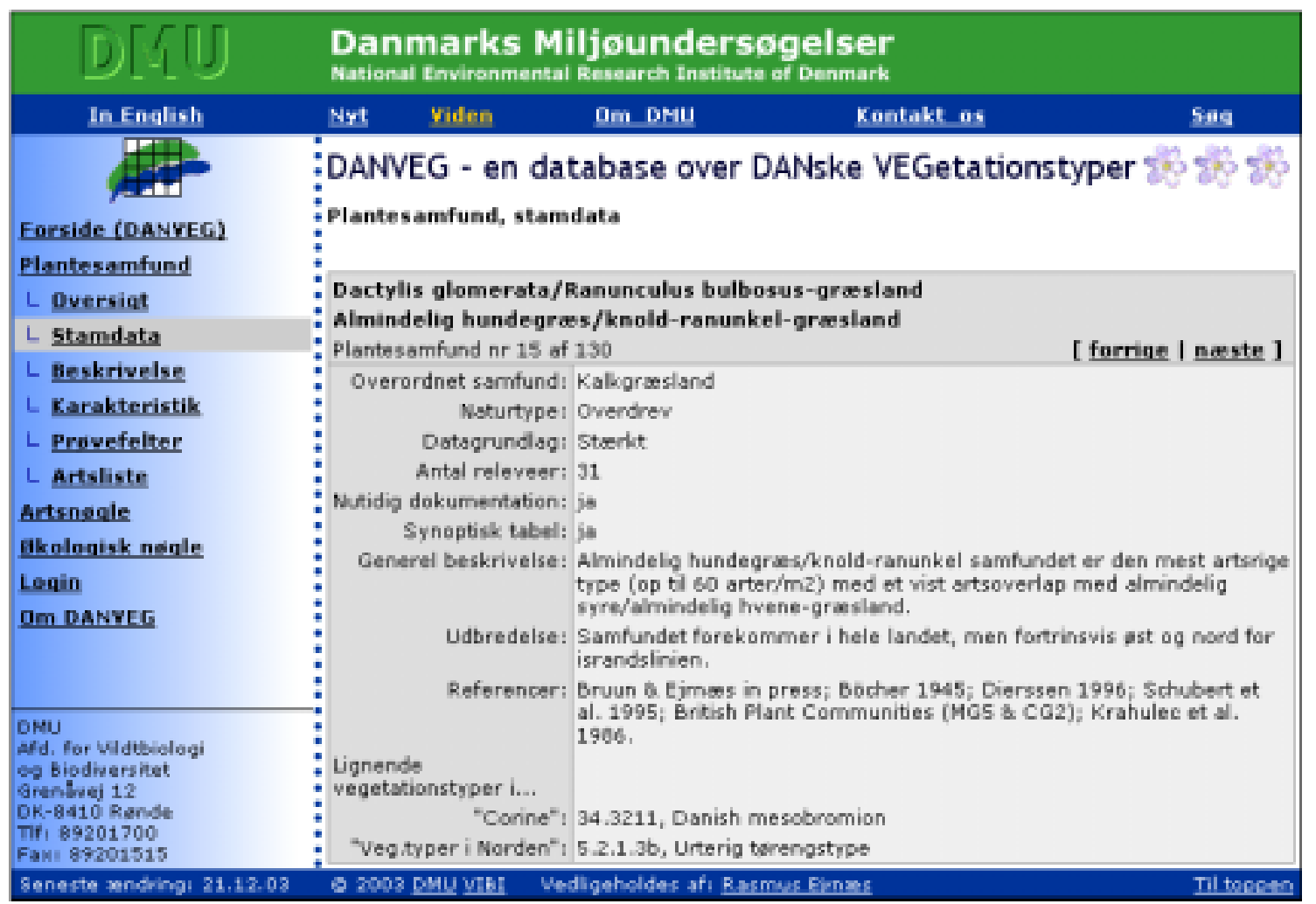

Figure 17. Screen dump from $w w w$. danveg. $k$, showing the core information regarding one of 130 plant communities in the database. 


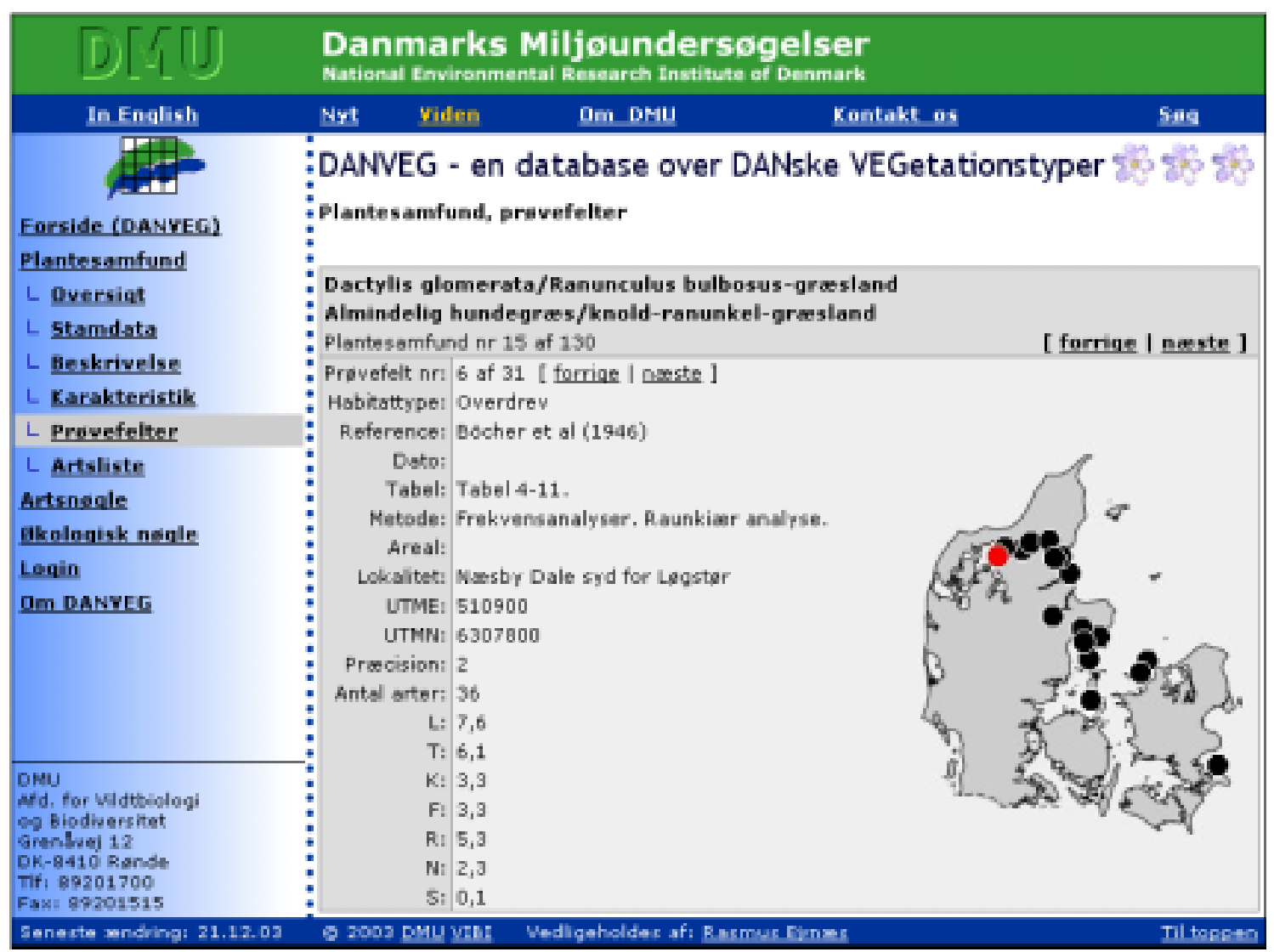

Figure 18. Screen dump from $w w w$.danveg.dk, showing the position of localities for the 31 species lists classified to a particular plant community. Detailed information is shown for one site within a highlighted locality. The shown locality is Nasby Dale South of Løgstфr, and the species list was reported by Böcher and co-workers in 1946.

\section{Interactive features}

Secondly, DANVEG offers an opportunity for active interaction with reference data by submission of a new species list using a species list manager. This new species list may be compared to all reference data, and DANVEG will calculate the most similar plant communities in the database (fig. 18), using passive ordination and nearest neighbour classification as described above. Following this classification, further comparisons between the new list and the most similar plant communities may be carried out. It is possible e.g. to look for particular species that are typical for the plant community, but absent in the new species list, or species in the species list that have not been recorded previously for that plant community (potential alien species or disturbance indicators).

Provided that the species list is appropriate for the three classification models developed during this project (e.g. non-forested sites for the habitat quality model, and grassland sites only for the Habitats Directive Type model), the list may also be classified according to these models. 


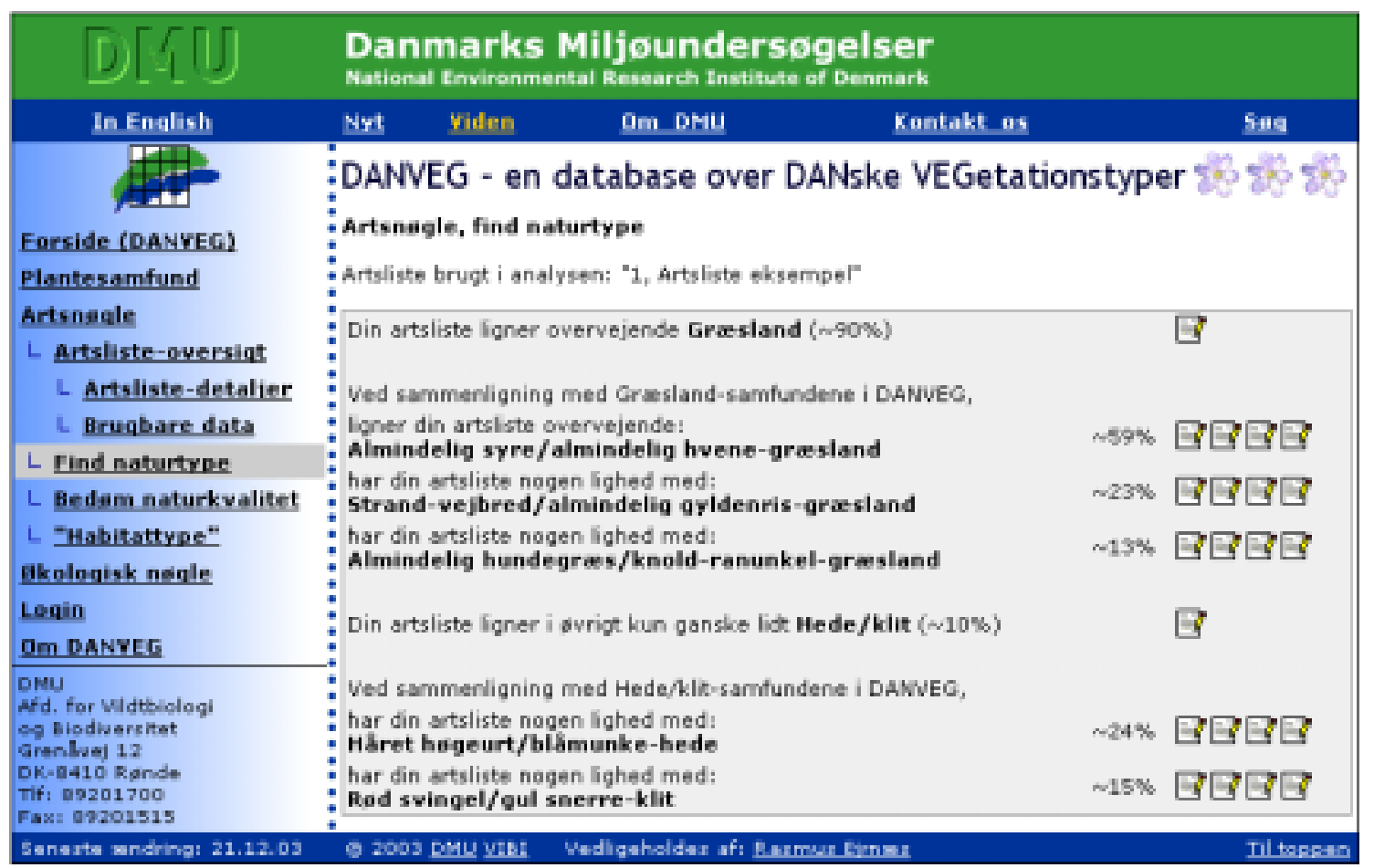

Figure 19. Screen dump from www.danveg.dk. A new species list has been submitted and subjected to classification. It appears that this new list has highest similarity to grassland vegetation, and that the most similar plant community is Rumex acetosaAgrostis capillaris grassland.

Although the interactive features are now accessible through the internet database at www.danveg.dk, the coming years will hopefully include opportunities for improving the user interface including attractive layout, informative help functions and illustrative images of the described plant communities. 


\section{References}

Anderson, J. E. 1991. A conceptual framework for evaluating and quantifying naturalness. Conservation Biology 5: 347-352.

Angermeier, P. L. \& J. R. Karr. 1994. Biological integrity versus biological diversity as policy directives. BioScience 44: 690-697.

Angermeier, P. L. 2000. The natural imperative for biological conservation. Conservation Biology 14: 373-381.

Angermeier, P. L. 2001. Reply to Povilitis: Another conservation conundrum. Conservation Biology 15: 536-538.

Anon. 1992 a. Council Directive 92/43/EEC of 21 May 1992 on the conservation of natural habitats and of wild fauna and flora. European Commission. Brussels.

Anon. 1999. Interpretation manual of European Union habitats. EUR 15 / 2. October 1999. European Commission, Brussels.

Austin, M. P. \& Smith, T. M. 1989. A new model for the continuum concept. Vegetatio 83: 35-47.

Austrheim, G. \& Eriksson, O. 2002. Plant species diversity and grazing in the Scandinavian mountains - patterns and processes at different spatial scales. Ecography 24: 683-695.

Barbour, M. T., Swietlik, W. F., Jackson, S. K., Courtemanch, D. L., Davies, S. P. \& Yoder, C. 2000. Measuring the attainment of biological integrity in the USA: a critical element of ecological integrity. Hydrobiologia 422/423: 453-464.

Barskogsutvalget. 1988. Forslag til retningslinjer for barskogsvern. DN-rapport 1988: 3: 1-96.

Berglund, B.E. 1991. The cultural landscape during 6000 years in southern Swedenthe Ystad project. Ecological Bulletins 41.

Callicott, J. B. \& Mumford, K. 1997. Ecological sustainability as a conservation concept. Conservation Biology 11: 32-40.

Callicott, J. B., Crowder, L. B. \& Mumford, K. 1999. Current normative concepts in conservation. Conservation Biology 13: 22-35.

Clemmensen, K.B. 2002. Naturkvalitet - fra begreb til vardisatningssystem. Botanisk Institut, Københavns Universitet.

Costanza, R., d'Arge, R., de Groot, R., Farber, S., Grasso, M., Hannon, B., Limburg, K., Naeem, S., O'Neill, R. V., Paruelo, J., Raskin, R. G., Sutton, P. \& van den Belt, M. 1997. The value of the world's ecosystem services and natural capital. Nature 387: 253-259.

DANVEG 2003. A database of published and unpublished accounts of terrestrial vegetation in Denmark, Accessible at: http://www.danveg.dk. 
Davies, C. E. \& Moss, D. 1999. EUNIS Habitat Classification. Draft Final Report. European Environment Agency. European Topic Centre on Nature Conservation, Copenhagen.

Degn, H. J. 2001. Succession from farmland to heathland: a case for conservation of nature and historic farming methods. Biological Conservation 97: 319-330.

DN 1996. Status for verneområde der verneverdiene er trua. DN-rapport 1996: 1: 1-73.

DN 1999. Kartlegging av naturtyper - verdsetting av biologisk mangfold. Direktoratet for naturforvaltning. DN-håndbok 13: 1-238.

Ejrnæs, R. 2000. Can we trust gradients extracted by Detrended Correspondence Analysis? Journal of Vegetation Science 11: 565-572.

Ejrnæs, R., Aude, E., Nygaard, B., Münier, B. 2002a. Prediction of habitat quality using ordination and neural networks. Ecological Applications 12: 1180-1187.

Ejrnæs, R., Bruun, H.H., Aude, E., Buchwald, E. In press. Developing a classifier for the Habitats Directive grassland types in Denmark using species lists for prediction. Applied Vegetation Science.

Ejrnæs, R., Liira, J., Poulsen, R. S. Submitted. Discrimination of semi-natural plant communities from abandoned fields by ordination and neural networks.

Ejrnæs, R., Näsman, U., Odgaard, B., Stenak, M., Aude, E., Jepsen, J. U. \& Topping, C. J. 2002b. Naturen i et kulturlandskab. In: Møller, P. G, Ejrnæs, R., Höll, A., Krogh, L. \& Madsen, J. (eds.), Foranderlige Landskaber. Syddansk Universitetsforlag, pp. 861.

Ellenberg, H., H.E. Weber, R. Düll, V. Wirth, W. Werner \& D. Paulissen 1992. Zeigerwerte von Pflanzen in Mitteleuropa. Scripta Geobotanica 18.

Elliot, R. 1994. Extinction, restoration, naturalness. Environmental Ethics 16: 135-144.

Emneborg, H. \& Götmark, F. 2000. The role of threat to areas and initiative from actors for establishment of nature reserves in southern Sweden 1926-1996. Biodiversity and Conservation 9:727-738.

Eriksson, O., Cousins, S.A.O. \& Bruun, H.H. 2002. Land-use history and fragmentation of traditionally managed grasslands in Scandinavia. Journal of Vegetation Science 13: 743-748.

Erikstad, L. \& Stabbetorp, O. E. 2001 - Natural areas - detailed mapping for the purpose of Environmental Impact Assesments (EIA). - Proceedings from the conference "Earth science and the natural heritage: interactions and integrated management". Scottish Natural Heritage, Edinburgh, november 1999: 224-227.

Erikstad, L. 1991. Østfold. Kvartargeologisk verneverdige områder. Norsk Institut Naturforsk. Utredn. 26: 1-61.

FAO 1998. Temperate and boreal forest assessment 2000. Terms and definitions. FRA Working Paper No. 1, Rome.Framstad, E., Økland, B., Bendiksen, E., Bakkestuen, V., Blom, H. \& Brandrud, T.E. 2002. Evaluering av skogvernet i Norge. NINA Fagrapport 54: 1-146. 
Franklin, J.F. 1993. The fundamentals of ecosystem management with applications in the Pacific Northwest. pp. 127-144 in G. Aplet, N. Johnson, J. Olson, \& V. Sample, eds. Defining Sustainable Forestry. Island Press, Washington, D.C., USA.

Frederiksborg County, unpublished. Data from an inventory of abandoned fields in Jaegerspris Skydeterran. Frederiksborg Amt, 2001.

Fremstad, E \& Moen, A. (eds.) 2001. Truete vegetasjonstyper i Norge. Norges teknisknaturvitenskapelige universitet, Vitenskapsmuseet, rapport botanisk serie 4: 2001: 1231.

Fremstad, E. 1997. Vegetasjonstyper i Norge. Norsk Inst. Naturforsk. Temahefte 12: 1279.

Gärdenfors, U., Hilton-Taylor, C., Mace, G.M. \& Rodríguez, J.P. 2001. The application of IUCN red list criteria at regional levels. Biol. Cons. 15: 1206-1212.

Gunn, A. S. 1991. The restoration of species and natural environments. Environmental Ethics 13: 291-310.

Harper, J. L. \& Hawksworth, D. L. 1994. Biodiversity: measurement and estimation. Preface. Phil. Trans. r. Soc. Lond. Ser. B. 345: 5-12.

Haugset, T., Alfredsen, G. \& Lie, M. 1996. Nøkkelbiotoper og artsmangfold $i$ skog. Siste Sjanse, Oslo.

Haugset, T., Whist, C. \& Kauserud, H. 1998. Verneverdig barskog i Telemark og AustAgder. Registreringer til utvidet verneplan for barskog. NOA-Rapport 1998: 2: 1-89.

Hill, M.O. 1979. DECORANA: A FORTRAN program for detrended correspondence analysis and reciprocal averaging. Cornell University, Ithaca, NY.

Justus, J. \& Sarkar, S. 2002. The principle of complementarity in the design of reserve networks to conserve biodiversity: a preliminary history. Journal of Bioscience 27: 421-435.

Karr, J. R. 1993. Defining and Assessing Ecological Integrity - Beyond Water-Quality. Environmental Toxicology and Chemistry 12: 1521-1531.

Karr, J. R. \& Dudley, D. R. 1981. Ecological Perspective on Water-Quality Goals. Environmental Management 5: 55-68.

Kotze, D. J. \& Samways, M.J. 1999. Support for the multi-taxa approach in biodiversity assessment, as shown by epigaeic invertebrates in an Afromontane forest archipelago. Journal of Insect Conservation 3: 125-143.

Kruskal, J. B. 1964. Non-metric multidimensional scaling: a numeric method. Psychometrika 29: 115-129.

Lameire, S., Hermy, M. \& Honnay, O., 2000. Two decades of change in the ground vegetation of a mixed deciduous forest in an agricultural landscape. Journal of Vegetation Science 11: 695-704.

Löfgren, R. \& Andersson, L. 2000. Sydsvenska lövskogar och andra lövbärande marker. Naturvårdsverket Rapport 5081.

Magurran, A. E. 1988. Ecological diversity and its measurements. Croom Helm Limited, London. 
Margules, C. \& Usher, M. B. 1981. Criteria used in assessing wildlife conservation potential: a review. Biological Conservation 21: 70-109.

Mark, S. 2001. Vurdering af naturkvalitet på strandenge. TemaNord 2001:517, p. 1-66. Nordisk Ministerråd, København.

McCune, B. \& M. J. Mefford. 1997. PC-Ord for windows, 3.04. MjM Software, Oregon, USA.

Minchin, P. 1987. An evaluation of the relative robustness of techniques for ecological ordination. Vegetatio 69: 89-107.

Moen, A. 1973. Norwegian national plan for mire nature reserves. Norsk geogr. Tidsskr. 27: 173-193.

Nilsson, C. \& Götmark, F. 1992. Protected areas in Sweden: Is natural variety adequately represented? Conservation biology 6: 232-242.

Nilsson, C.1984. Criteria for the biological evaluation of the natural environment from a conservation viewpoint. Naturvårdsverket rapport, SNV PM 1881: 1-55.

Nitare, J. \& Norén, M. 1992. Nyckelbiotoper kartläggs i nytt project vid Skogstyrelsen. Svensk botanisk Tidskrift 86: 219-226.

Norén, M., Nitare, J., Larsson, A., Hultgren, B. \& Bergengren, I. 2002. Handbok för inventering av nyckelbiotoper. Skogstyrelsen, Jönköbing.

Noss, R. F. 1990. Indicators for monitoring biodiversity: a hierarchical approach. Conserv. Biol. 4: 355-364.

NOU 1983. Naturfaglige verdier og vassdragsvern. Norges offentlige utredninger 1983: 42: 1-376.

Nygaard, B., S.Mark, A.Baattrup-Pedersen, K.Dahl, R.Ejrnæs, J.Fredshavn, J.Hansen, J.E.Lawesson, B.Münier, P.F.Møller, M.Risager, F.Rune, J.Skriver \& M.Søndergaard . Naturkvalitet - kriterier og metodeudvikling. Faglig rapport fra DMU 285, 1-118. 1999. Danmarks Miljøundersøgelser.

Odgaard, B.V. 1994. The Holocene vegetation history of northern West Jutland, Denmark. Opera Botanica 123: 1-171.

Økland, R. H. 1990. Vegetation ecology: theory, methods and applications with reference to Fennoscandia. Sommerfeltia Suppl. 1.

Påhlsson, L. 1998. Vegetationstyper i Norden. TemaNord 1998: 510: 1-708. Nordisk Ministerråd, København.

Povilitis, T. 2001. Toward a robust natural imperative for conservation. Conservation Biology 15: 533-535.

Prendergast, J. R., Quinn, R. M. \& Lawton, J. H. 1999. The gaps between theory and practice in selecting nature reserves. Conservation biology 13: 484-492.

Prendergast, J. R., Quinn, R. M., Lawton, J. H., Eversham, B. C. \& Gibbons, D. W. 1993. Rare species, the coincidence of diversity hotspots and conservation strategies. Nature 365: 335-337. 
Pressey, R. L., Humphries, C. J., Margules, C. R., Vane-Wright, R. I. \& Williams, P. H. 1993. Beyond opportunism: key principles for systematic reserve selection. Trends in Ecology and Evolution, 8:124-128.

Rabinowitz, D., Cairns, S. \& Dillon, T. 1986. Seven forms of rarity and their frequency of the flora of the British Isles. In M.E. Soulé (Ed.), Conservation Biology, pp. 182204. Sinauer associates, Inc., Sunderland, Massachusetts.

Ratcliffe, D. A. 1977. A nature conservation review. The selection of biological sites of national importance to conservation in Britain. Cambridge University Press, London.

Rebelo, A. G. 1994. Iterative selection procedures: centres of endemism and optimal placement of reserves. Strelitzia 1: 231-257.

Ripley, B. D. 1996. Pattern recognition and neural networks. Cambridge University Press, Cambridge. 403 p.

Rolstad, J., Framstad, E., Gundersen, V. \& Storaunet, K.O. 2002. Naturskog i Norge. Definisjoner, фkologi, og bruk i norsk skog-og miljøforvaltning. Aktuelt fra skogforskningen 2000: 1: 1-53.

Rolstad, J., Gjerde, I., Gundersen, V. S., Sætersdal, M. 2002. Use of indicator species to assess forest continuity: a critique. Conservation Biology: 253-257.

SAS Institute, Inc. 1990. SAS/Stat User's Guide, Fourth Edition. SAS Institute, Inc., pp 120-121.

Scott, J.M. \& Jennings, M.D. 1998. Large area mapping of biodiversity. Ann. Miss. Bot. Garden 85: 34-47.

Skov- og Naturstyrelsen 1994. Strategi for baredygtig skovdrift. Skov- og Naturstyrelsen, København.

Smith, P. G. R. \& Theberge, J. B. 1986. A review of criteria for evaluating natural areas. Environmental Management 10: 715-734.

Stoltze, M. \& Pihl, S. 1998. Redlist 1997. Rare plants and animals in Denmark. Ministery of Energy and Environment, National Environmental Research Institute, The National Forest and Nature Agency. (In Danish). 219 p.

Svenning J.-C. 2002. A review of natural vegetation openness in north-western Europe. Biological Conservation 104:133-148

Tanninen, T., Storrank, B., Haugen, I., Møller, P.F., Löfgren, R., Thorsteinsson, I., \& Ragnarsson, H. 1998. Natural Woodlands in the Nordic Countries. TemaNord 1998:6: 1-101.Nordic Council of Ministers, Copenhagen.

Taylor, P. W. 1981. The ethics of respect for Nature. Environmental Ethics 3: 197-218.

Ten Brink, B.J.E. 2000. Biodiversity indicators for the OECD Environmental Outlook and Strategy: a feasibility study. RIVM report 402001014, Bilthoven, The Netherlands.

Ten Brink, B.J.E., Tekelenburg, T. 2002. Biodiversity: how much is left? The Natural Capital Index framework (NCI). RIVM, Bilthoven.

UNEP 1995. Global Biodiversity Assessment. UNEP, Annex 6, Glossary. United Nations, New York. 
United Nations. 1992. Convention on biological diversity. United Nations Conference on Environment and Development, 1992, Rio de Janeiro, Brazil. United Nations, New York.

Usher, M. B. 1986. Wildlife conservation evaluation: attributes, criteria and values. In M. B. Usher (Ed.), Wildlife conservation evaluation (pp. 3-44). Chapman and Hall Ltd., London.

Van Dobben, H.F., ter Braak, C.J.F. \& Dirkse, G.M. 1999. Undergrowth as a biomonitor for deposition of nitrogen and acidity in pine forest. Forest Ecology and Management, 114, 83-95.

Van Hinsberg, A., Van der Hoek, D.-J., de Heer, M., Ten Brink, B. \& Van Esbroek, M. 2003. Informing Policy-makers about changes in Biodiversity - A Dutch approach to the aggregation and processing of monitoring data for the achievement of national Biodiversity indicators like the Natural Capital Index. Proceedings from the workshop: Mapping and monitoring of natural areas in the Nordic countries, Fugls $\varnothing$, Denmark, November 1-3, 2002.

Vane-Wright, R. I., Humphries, C. J. \& Williams, P. H. 1991. What to protect? Systematics and the agony of choice. Biological Conservation 55: 235-254.

Venables, W.N. \& B.D. Ripley. 1997. Modern Applied Statistics with S-Plus. Springer Verlag. 548 pp.

Vera F.W.M. (2000) Grazing ecology and forest history. CABI Publishing, Oxon, UK.

Vitousek, P. M., Mooney, H. A., Lubchenco, J. \& Melillo, J. M. 1997. Human domination of Earth's ecosystems. Science 277: 494-499.

Westhoff, V. (1983). Man's attitude towards vegetation. In: W. Holzner, M.J.A. Werger \& I. Ikusima (eds.) Man's impact on vegetation. Geobotany 5. Dr. W Junk Publishers. The Hague.

Whittaker, R. H. 1972. Evolution and measurement of species diversity. Taxon 21: 213251.

Willers, B. 2000. A response to "Current normative concepts in conservation" by Callicott et al. Conservation Biology 14: 570-572.

Zar, J.H. 1996. Biostatistical Analysis. 3rd edition. Prentice-Hall, London.

Zobel, M. 1997. The relative role of species pools in determining plant species richness: an alternative explanation of species coexistence. Trends in Ecology and Evolution 12: 266-269. 